\title{
A COMPARATIVE STUDY OF THE LEADERSHIP PREFERENCES OF CHINESE MILLENNIALS AND NON-MILLENNIALS
}

BY

YIWAN WANG

\author{
A thesis \\ submitted to Victoria University of Wellington \\ in fulfillment of the requirements for the degree of \\ Master of Commerce in Management
}

Victoria University of Wellington

(2020) 


\begin{abstract}
There has been a lack of academic research focusing on the generational differences in leadership preferences in the Chinese context, particularly in terms of the Millennial generation. In what way, if at all, do the leadership preferences of Chinese Millennials differ from those of Chinese non-Millennials? Such was the guiding question of the study I present in this thesis. The purpose of this study was to explore and compare the leadership preferences of Chinese Millennials and non-Millennials, so as to allow academics and organizations to better understand the leadership preferences of Chinese Millennials, and recognize the differences/similarities in leadership preferences between the employees of different generations in China. A total of 460 participants participated in this study (230 are Millennials, 230 non-Millennials), all of whom were Chinese living in mainland China, and full-time workers with at least one year of work experience. The study used a questionnaire to collect data regarding participants' leadership preferences, which was then analyzed in three steps (i.e., a primary analysis and two follow-up analyses). The results show that, overall, Chinese Millennials have similar leadership preferences to non-Millennials. I draw on relevant literature to theorize about the social and psychological mechanisms that might underpin my findings. Potential explanations include traditional Chinese culture being consolidated and inherited; people having similar fundamental needs (regardless of generational membership), and therefore similar leadership preferences; and the impact of intergenerational interactions and a shared organizational environment. By increasing understanding of the research evidence that exists about leadership preferences across generations, leadership challenges in the multi-generation workforce can be overcome. A better understanding of Millennials' leadership preferences, as well as differences and similarities in these preferences among different generations, also enables organizations and leaders to better lead the growing number of Millennial employees in China.
\end{abstract}

Keywords: generational differences, leadership preferences, Millennials, Chinese context 


\section{ACKNOWLEDGEMENTS}

Without the support of the people around me, it would not have been possible for me to finish this thesis, especially in such a special and tough year. I would like to acknowledge those who have provided me with help and support.

First and foremost, I am deeply grateful to my supervisor, Ben Walker, for his full confidence in me, expert advice, careful guidance, generous help, as well as endless support and encouragement. You challenged me to think critically and inspired me to think more deeply about my study. You guided me through the process and helped me to achieve the goals step by step and advised me to find a new way out when I was in trouble. I cannot offer enough thanks for your supervision. Thank you for being with me on this journey.

I would like to thank the Management Faculty and staff for not only providing support but also understanding. I also would like to thank other master's students who have struggled to do research and write thesis like me. Every time we met in the study room, we encouraged each other and shared our experience.

Lastly, I also wish to thank each of my families and friends in my home country, China. Thank you for your support and inspiration. I would not be here today without you all. 


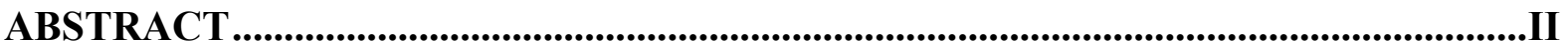

ACKNOWLEDGEMENTS ........................................................................................................III

TABLE OF CONTENTS ......................................................................................... IV

LIST OF TABLES ........................................................................................................... VI

LIST OF FIGURES .....................................................................................................

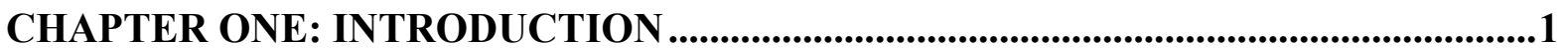

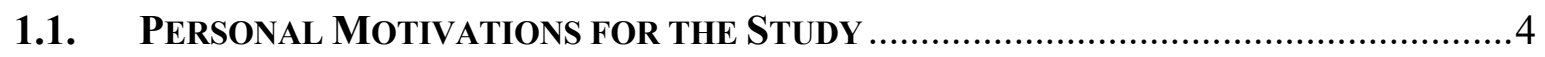

CHAPTER TWO: LITERATURE REVIEW .......................................................................5

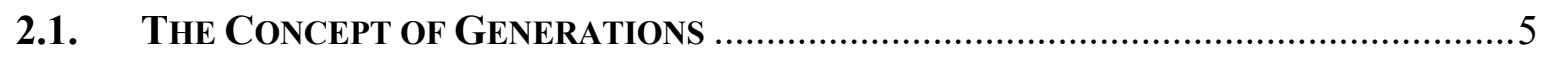

2.2. CRITIQUES OF RESEARCH ON GENERATIONAL DIFFERENCES ................................6

2.3. GENERATIONAL DIFFERENCES AND LEADERSHIP ............................................9

2.3.1. Generational Differences in Leadership Preferences......................................... 10

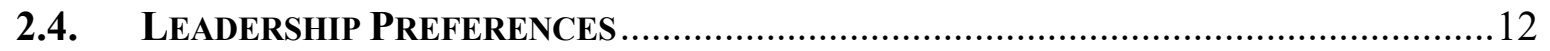

2.4.1. Transformational/Transactional Leadership...................................................... 13

2.4.2. Implicit Leadership Theory .......................................................................... 13

2.4.3. Culturally Endorsed Leadership Theory …………….................................... 14

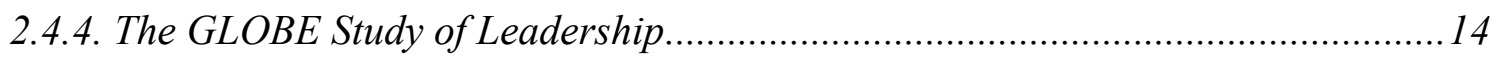

2.5. GENERATIONAL DIFFERENCES AND LEADERSHIP PREFERENCES IN CHINA..........15

2.5.1. Generations in China: Millennials vs. Non-Millennials...................................... 15

2.5.2. The Psychology of Chinese Millennials .............................................................. 17

2.5.3. General and Generation-Specific Leadership Preferences in China ....................18

CHAPTER THREE: METHODOLOGY ….................................................................

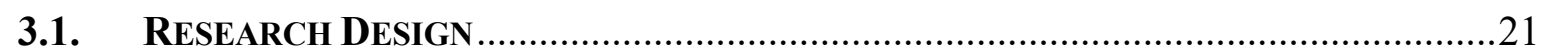

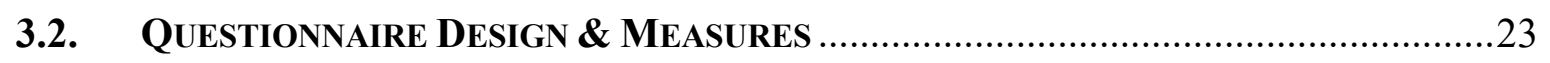

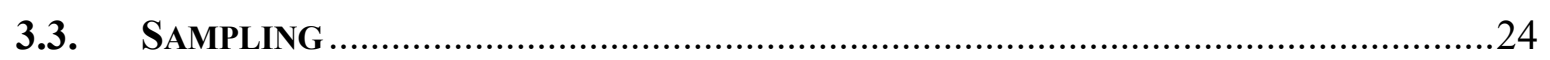

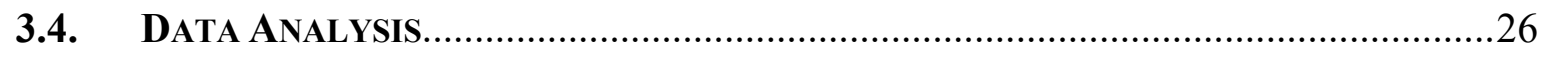

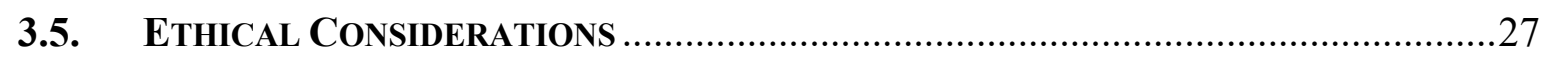




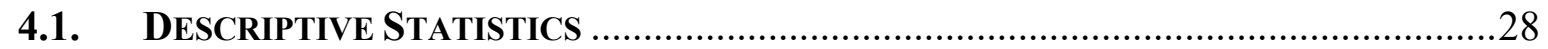

4.2. PRIMARY ANALYSIS: INDEPENDENT SAMPLES T-TEST ........................................

4.3. Follow-UP ANAlysis \#1: Age-BaSEd ONE-WAy ANOVA...............................33

4.4. FOLLOW-UP ANALYSIS \#2: INDEPENDENT SAMPLE T-TEST BETWEEN THE

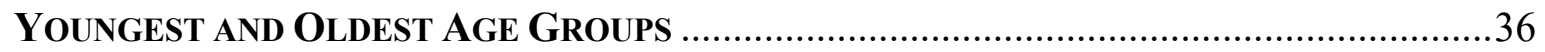

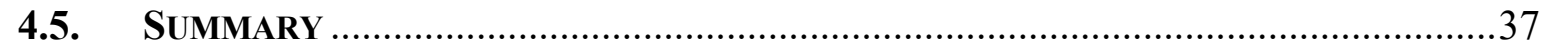

CHAPTER FIVE: DISCUSSION AND CONCLUSION .................................................39

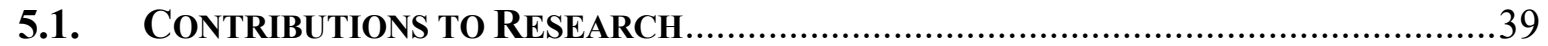

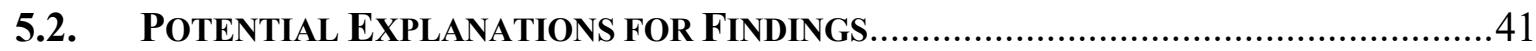

5.2.1. Traditional Chinese culture is consolidated and inherited ...................................41

5.2.2. People have similar fundamental needs, regardless of generational membership 43

5.2.3. The impact of intergenerational interactions and a shared organizational

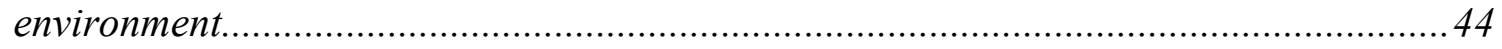

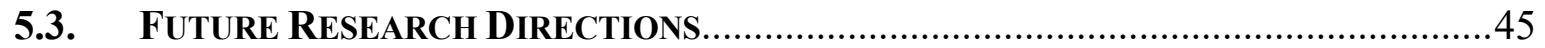

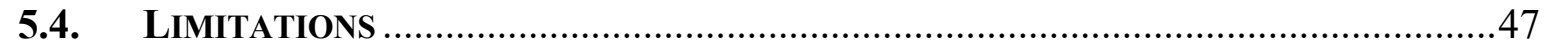

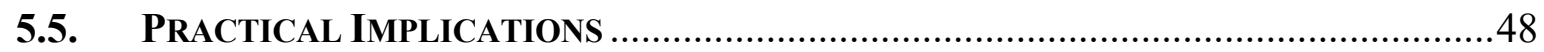

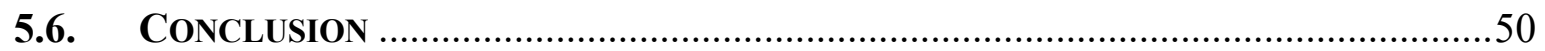

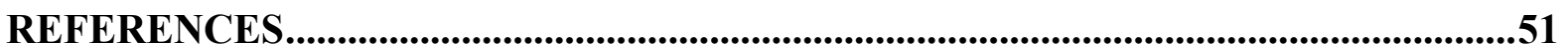

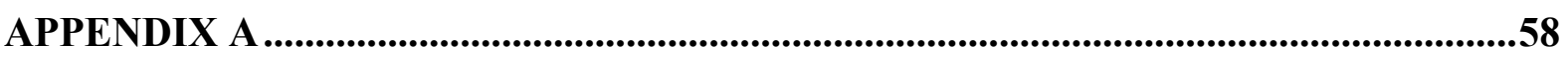

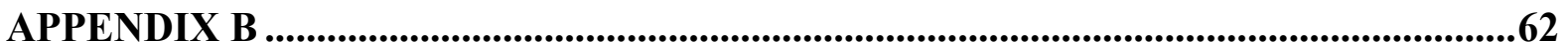

APPENDIX C

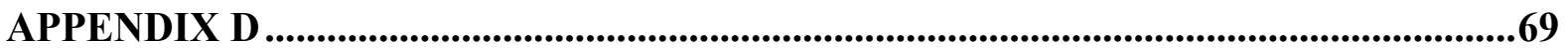

ENGLISH VERSION OF THE QUESTIONNAIRE .......................................................69

APPENDIX E

CHINESE VERSION OF THE QUESTIONNAIRE ....................................................73 


\section{LIST OF TABLES}

TABLE 1- DEMOGRAPHIC CHARACTERISTICS OF PARTICIPANTS .28

TABLE 2 - MEAN RATINGS OF 55 LCBS - CHINESE NON-MILLENNIALS VS. CHINESE MILLENNIALS 30

TABLE 3 - THE TOP 10 HIGHEST RATED LCBS AND THE 10 LOWEST RATED LCBS FOR MILLENNIALS AND NON-MILLENNIALS 31

TABLE 4 - INDEPENDENT SAMPLES T-TEST BETWEEN CHINESE MILLENNIALS AND NONMILLENNIALS 33

TABLE 5 - AGE-BASED ONE-WAY ANOVA .35

TABLE 6 - MEANS AND STANDARD DEVIATIONS FOR FOUR LCBS BY AGE GROUP .35

TABLE 7 - INDEPENDENT SAMPLES T-TEST BETWEEN THE YOUNGEST AND OLDEST AGE GROUPS 


\section{LIST OF FIGURES}

FIGURE 1 - DATA ANALYSIS PROCEDURE. 


\section{CHAPTER ONE: INTRODUCTION}

The workforce is undergoing a generational shift and is increasingly comprised of workers from Generation Y - a group also known as Millennials (Tulgan, 2004). As Smola and Sutton (2002) stated, "as we enter the new millennium and face the entrance of another generation of workers into the changing world of work, managers are encouraged to deal with the generational differences that appear to exist among workers" (p. 363). Hill (2002) pointed out that in many cases nowadays, the older generation is managing the younger generation of employees: the biggest challenge of managing Millennial employees in the workplace is that older generations must recognize the similarities (and differences) between themselves and their younger colleagues. Likewise, Ali et al. (2009) suggest that understanding generational differences can enable managers to construct strategies and adapt techniques to fully stimulate the skills and abilities of all employees, so as to support the realization of organizational goals and objectives.

Motivated by these views, management researchers have devoted much attention to exploring generational differences in work-related attitudes and values (e.g., Zemke et al., 2000; Smola \& Sutton, 2002; Sessa et al., 2007; Chen \& Choi, 2008; Costanza et al., 2012; Lester et al., 2012; Ahn \& Ettner, 2014), with a particular focus on comparing Millennials with older generations. The notion of generational differences, however, has not been without controversy. For one, empirical evidence as to the existence of generational differences at work is said to be relatively weak (Costanza et al., 2012). In addition, systematic reviews (e.g., Parry \& Urwin, 2011; Costanza et al., 2012; Rudolph \& Zacher, 2017; Rudolph, Rauvola \& Zacher, 2018) of generational differences at work have suggested that generational differences have no appreciable impact on the work process and results as well as work-related attitudes (Parry \& Urwin, 2011; Rudolph, Rauvola \& Zacher, 2018). Empirical research has also emerged (e.g., Westerman and Yamamura, 2007; Kowske et al., 2010) suggesting that there are no substantial generational differences in work-related attitudes and values.

Within the field of management, one sub-area where research on generational differences has grown significantly in recent times is leadership preferences (Arsenault, 2004). Understanding any extant generational differences in leadership preferences can be helpful in that it can enable leaders to adjust their behaviours in a practical way, so as to enhance the performance of their subordinates, and ultimately, increase organizational 
productivity (Limsila \& Ogunlana, 2008). Arsenault (2004) found that older generations are more likely to believe that honesty is an absolute imperative in leadership, and that leaders must view followers as more than employees (i.e., friends), while Millennials are more likely to prefer that leaders have the determination to achieve goals and ambitions than older generations. Chou (2012) summarized that Millennials manifest a higher level of need for trust and support from their leaders and organizations, while Huff (2006) reported that younger generations, and especially Millennials, prefer their leaders to provide avenues for self-development. Likewise, Sessa et al., (2007) stated that leaders should be supportive of Millennials, and Lyons and Kuron (2014) summarized—-based on a review of relevant literature - that the younger generation seems to be looking for leaders who provide a work environment that is conducive to personal accomplishment, rather than leaders who focus largely on tasks and organizational success.

Importantly, though, most published work on generational differences in leadership preferences is based on studies in Western contexts, with significantly less research exploring this issue beyond Western contexts. However, exploring generational differences in leadership preferences in non-Western contexts, and in particular-in the social, cultural, and economic context of China-is a worthwhile endeavor for at least two reasons.

First, Chinese workplaces are increasingly characterized by multiple generations of employees working together (Yang, Yu \& Wu, 2018). As such, there is a need for Chinese managers and organizations to understand how to most effectively lead the current multigenerational workforce comprised of both Millennials and older generations. In order to do so, it is important for research to explore - and thus, organizations to understand - the newer Chinese generation's work-related attitudes and values, whether they differ substantially from those of previous generations, and if so, in what specific ways (Chen \& Lian, 2015). Zhao and $\mathrm{Xu}$ (2019) also stated that exploring possible differences between Chinese millennials and older generations in work settings is a priority for scholars and practitioners, because Millennials already constitute a large proportion of the Chinese labor force.

Second, Chinese Millennials may constitute a particularly unique group in Chinese society and organizations that differs in important work-related ways from previous generations. The Chinese government implemented the "One Child Policy" in 1980, which was a major and unique social change in China. It is believed this policy has had a significant impact on the characteristics and personalities of children born and raised in this era (Yi et al, 2010). Those born in the wake of this policy (i.e., Chinese Millennials, also sometimes known as the "One Child Generation") are believed to have characteristics and values that are 
very different from the older generations (Sun \& Wang, 2010; Li, 2015). For example, researchers (e.g., Zhao, 2018; Yi et al., 2010; Sun \& Wang, 2010) have noted that Chinese Millennial employees demonstrate different characteristics to older generations, including a desire to be heard and recognized by organizations society at large (Zhao, 2018), more individualism (Yi et al., 2010; Sun \& Wang, 2010), a stronger future orientation, and a heightened focus on their own planning and goals (Yi et al., 2010). However, other researchers (Yi et al., 2010; Yi et al., 2015) have also found that Chinese Millennials still maintain the same traditional values as older generations, such as loyalty, honesty, and kindness, and that these traditional values still influence their attitudes and conduct in the workplace. Considering generational similarity from a cultural perspective, these researchers (e.g., Lu \& Kao, 2002; Koehn, 2001) argue that the enduring influence of traditional Chinese values (i.e., collectivist values; the Confucian concept of trustworthiness) on Millennials' work-related attitudes has led to generational similarity. Overall, then, there is still uncertainty as to whether Chinese Millennials differ significantly from Chinese nonMillennials in respect of their work-related attitudes and values.

Mindful of the above considerations, a small number of researchers have recently attempted to study the general issue of generational differences in work-related attitudes and values in China (e.g., Sun \& Wang, 2010; Yi et al., 2010; Chen \& Lian, 2015; Yang, Yu \& $\mathrm{Wu}, 2018$ ), as well as the more specific issue of the leadership preferences of Chinese Millennials (e.g., Yi et al., 2010; Xie \& Chen, 2014; Jiang \& Hui, 2016; Ren et al., 2018; Lin $\&$ Sun, 2018) and generational differences in leadership preferences (e.g., Yi et al., 2010). These studies have found that Chinese Millennials tend to expect more from their managers (Yi et al., 2010), and demonstrate a preference for more supportive leadership that facilitates decreases in their negative emotions (Jiang \& Hui, 2016), as well as participative and coaching leadership (Xie \& Chen, 2014; Ren et al., 2018). While leadership preferences were not a core focus of the study, Yi et al. (2010) also found significant generational differences in preferences for only 4 leadership traits (i.e., ambitious, mentor, team player and loyal) among 15 leadership traits between the Cultural Revolution Generation (i.e., born in the 1960s), Social Reform Generation (i.e., born in the 1970s) and Millennials (i.e., born in the 1980s and 1990s). The Cultural Revolution Generation was significantly different from the Social Reform Generation and Millennials in their preference for ambitious and mentor. The significant differences in the preference for team player were only found between the Cultural Revolution Generation and Millennials. In terms of the preferences for loyal, 
Millennials were significantly different from the Cultural Revolution Generation, but the Social Reform generation was not different from either Millennials or Cultural Revolution.

While this research is a promising first step, much remains uncertain and unknown about generational differences in leadership preferences in the context of China, particularly in terms of the Millennial generation: in what way, if at all, do the leadership preferences of Chinese Millennials differ from those of Chinese non-Millennials? Such was the guiding question of the study I present in this thesis. This study explored and compared the leadership preferences of Chinese Millennial and non-Millennial employees, so as to allow academics and organizations to better understand the leadership preferences of Chinese Millennials and recognize the differences/similarities in leadership preferences between the employees of younger generation and past generations in China. By understanding any such differences (or similarities), organizations and managers will be better positioned to manage the growing number of Millennial employees in the workforce in China, as well as lead the mixed workforce of younger and old generations more effectively.

\subsection{Personal Motivations for the Study}

My interest in this research topic stems from the fact that my friends and I are all Millennials. Our parents, their siblings, and most of their friends, however, were born in the 1960s and 1970s. I often hear my parents and their peers say that young people of my generation are very different from the older generations in thoughts and behaviours, and that we are difficult to manage in workplaces. In addition, my friends complain to me about their leaders at work, who tend to belong to the older generations, or even question their leadership approach. For example, some think that in addition to talking about work content, it is difficult to communicate with their leaders, because the generational differences lead them to have very different expressions and interests, so that it is hard to find shared interests. But at the same time, I am also frequently surprised that the Millennials around me seem to have some of the same ideas and insights about leadership that older generations have. All of these experiences made me wonder how substantial the gap between the leadership preferences of Millennials and older generations actually is in reality. Thus, in this research, I sought to better understand any generational differences in leadership preferences between Chinese Millennials and non-Millennials. 


\section{CHAPTER TWO: LITERATURE REVIEW}

This chapter reviews relevant literature associated with my research question. It outlines the theoretical background on generations and leadership preferences. In addition, this chapter also reviews existing research on generation and leadership preferences in the Chinese context. Through this literature review, I identified a gap regarding understanding of generational differences in leadership preferences in the context of China. There is debate as to whether the generational difference affects leadership preference and there is insufficient empirical evidence to support the existence of generational difference in leadership preference. Meanwhile, most of the research on generational differences in leadership preferences was carried out in the Western context. In the Chinese context, how generational differences influence the leadership preferences of Millennials and non-Millennials has not been well answered.

\subsection{The Concept of Generations}

The theory of generations was first posed by Karl Mannheim (1893-1974) who defined a generation as a group of people with a collective memory because they share a common birth period and move through time together (Mannheim, 1970). It is broadly accepted that similarities exist between people within the same birth cohorts, and that differences in characteristics also exist between generations. Rudolph, Rauvola and Zacher (2018) summarized the early research on generations within the field of sociology, explaining that large-scale social changes associated with long-term dynamics spanning decades can be used to explain generational differences. From the perspective of sociology, people of the same generation, by virtue of being born during the same time span, have shared and therefore similar life experiences. A generation could be shaped by many critical factors, including changes in attitudes across society; changes in social, economic, and public policies; and major social events (Kupperschmidt, 2000). The shared experiences of social events and changes not only affect that person's view of the world, but also help shape the attitudes, beliefs and opinions of everyone born in that period to build collective generational characteristics, traditions, and culture (Yi et al., 2010). Kupperschmidt (2000) stated that as a result of these shared experiences, people within a generation will develop their own generational characteristics, including values, attitudes, beliefs and behaviours. These characteristics may influence a generation's work-related attitudes, work motivations and outcomes in their working life (Kupperschmidt, 2000). In other words, each generational 
cohort is embedded within and exposed to its own idiosyncratic social context. This exposure not only influences people's view of the world, but also shapes their beliefs and perceptions, and subsequently creates a collective peer mindset amongst members of that generation, which may subsequently affect people's work-related attitudes.

Scholars have noted that specific historical events and experiences are particularly prominent in the formation of collective consciousness of generations (McHugh, 2007). This means that because people in the same generational cohort experience common social events, influences, and changes, there is likely to be a shared "collective consciousness" amongst them. Collective consciousness refers to the set of shared ideas, values and beliefs amongst a particular social group, which arise via social construction (Burns \& Engdahl, 1998). Collective consciousness suggests that when a group of people experience the same historical event, a generation is formed (Mannheim, 1970). In modern industrialized societies, social institutions and structures, such as institutional and cultural arrangements (Burns \& Engdahl, 1998) and education (Cole, 2020) all play a role in generating and shaping collective consciousness. The collective consciousness of each generation leads to unique and distinguishable characteristics, which are the common or widely-shared features of members of that generation (Rudolph, Rauvola \& Zacher, 2018). In other words, as each generation matures in its specific context, so too does each generation develop characteristics that are different from those of previous and subsequent generations (Macky, Gardner \& Forsyth, 2008). These are the basic mechanisms that produce generational differences.

\subsection{Critiques of Research on Generational Differences}

The concept of generational differences is not without controversy. Walker (1993) has pointed out that emphasis on the role of generations in shaping the psychosocial manifestation of attitudes, motivations and behaviours is akin to falling prey to a "cohort trap". This notion of a "cohort trap" is intended to reflect the phenomenon of researchers attributing unwarranted weight to the role of generations in determining people's attitude, motivations, and behaviours, and failing to recognize the various other social forces (e.g., national culture, familial influences) that contribute to one's psychology (Walker, 1993; Parry \& Urwin, 2011; Rudolph \& Zacher, 2017). In addition, Macky, Gardner and Forsyth (2008) present two key critiques of generational differences. First, it is problematic to assume that all members of any given generation will experience the same major socio-cultural and/or socio-economic events in the exact same way (i.e., independent of social class, gender, 
race, or ethnic culture) (Macky, Gardner \& Forsyth, 2008). Second, it is difficult to separate generational differences from differences stemming from age (maturity), occupation, or life stage (Macky, Gardner \& Forsyth, 2008). Similarly, Costanza and Finkelstein (2015) stated the main challenge in studying generational differences is that it is difficult to distinguish the effects of three related but very different factors: age (that is, aging-related variations related to life stage and maturity), period (that is, related to specific history time period) and cohorts. Regardless of the method used, generational differences uncovered by researchers are not necessarily attributable to or determined by generations (i.e., the range of birth years). On the contrary, there are other factors that can better support the theoretical explanation of these differences, such as personal characteristics, external environmental factors such as technology, and people's developmental changes over time (Costanza \& Finkelstein, 2015). For example, the view that Millennials are lazy has been promoted in magazines and newspapers, but this generational slander appears every two decades or so: it is hard to know whether this is a generational difference or just a characteristic of a certain age group (Costanza \& Finkelstein, 2015).

Considering the effect of life stage, Rudolph and Zacher (2017) proposed a lifespan developmental perspective to extend the critique of research on generations in the work context. They attempted to understand generations from a lifespan framework, which explained the time period and history-graded influences (Rudolph \& Zacher, 2017) that may impact individuals' attitudes, values, beliefs and behaviours. They criticized a common assumption underpinning the generational differences perspective: namely, that the constituents within a generation are consistent (i.e., common birth cohorts, shared experience), and argued that the perspective of generations overweights the variability between generational groups, but diminishes the intraindividual variability in characteristics (i.e., values, attitudes, beliefs, motivations and behaviours) over time associated with the aging process. These criticisms from the lifespan perspective argue for a focus on interindividual differences, rather than overemphasizing the role of generations in explaining the differences in characteristics between younger and older generations that may be caused by age-related changes (Rudolph, Rauvola, \& Zacher, 2018). Similarly, Smola and Sutton's (2002) results suggest that while there may be some generational differences in work values, such values also naturally change as workers grow older.

In addition, in direct contrast to those studies that focus on generational differences, many researchers have studied and sought to explain generational similarities. One way researchers have theorized about generational differences is in relation to culture. For 
example, Lu and Kao (2002) studied the characteristics of younger and older generations in Taiwan, and found a coexistence of generational similarities and differences due to the stability of culture: as the culture remains constant, the younger generations under the influence of that culture retain the core traditional values (i.e., collectivist orientation) like the older generations ( $\mathrm{Lu} \& \mathrm{Kao}, 2002)$. According to Lu and Kao (2002), this is because the transformative and inheriting power of traditional culture. Although Western culture has brought huge challenges to traditional Eastern culture and has an important impact on the younger generation in Taiwan, traditional culture may not simply disappear or be replaced by Western culture in the process of social modernization. Instead, they may have surprising transformative powers that can both protect the core traditions of indigenous cultures while absorbing useful elements of foreign cultures ( $\mathrm{Lu} \& \mathrm{Kao}, 2002)$, thus continuing to have an impact on future generations. Furthermore, reviewing other literature, McHugh (2007) pointed out that with the passage of time, some major events and experiences were compiled into historical deeds and evolved into national stories or certain national characteristics. Their influence permeates daily life and is inherited by future generations. This provides another perspective on generational similarities that the shared experiences of previous generations (e.g., memories and reflections of the Second World War) may be transformed into a part of the culture and passed on, thus, having similar effects on subsequent generations. This statement by McHugh (2007) also emphasizes the effect of cultural heritage on generational similarity.

In addition to considering generational similarity from a cultural perspective, another perspective considers the effect of interactions between generations. Kupperschmidt (2000) pointed out that although each generation has different attitudes and values, they may be influenced by previous and subsequent generations. As a result of these interactions and influences, one generation may become similar to other generations. In earlier literature, Mannheim (1970) mentioned the effect of interaction between different generations on the reduction of generational differences. He noted the fact that the transition from one generation to another occurs continuously, and this fact tends to make this interaction smoother. In this interaction process, it is not the oldest person who will meet the youngest person immediately; the initial connection is made by intermediary generations (Mannheim, 1970). All intermediaries play their role: while they cannot eliminate generational differences, they can at least mitigate them (Mannheim, 1970).

A final criticism of the notion of generational differences is that there is relatively weak empirical evidence of their existence at work (Costanza et al., 2012). Systematic 
reviews of generational differences at work (e.g., Parry \& Urwin, 2011; Costanza et al., 2012; Rudolph \& Zacher, 2017; Rudolph, Rauvola \& Zacher, 2018) have found that generational differences have no appreciable impact on the work process and results as well as workrelated attitudes. In fact, recent research has provided evidence suggesting that there are no (or only very slight) generational differences in work-related attitudes (Costanza et al., 2012). For example, Westerman and Yamamura (2007) found there were no significant differences in job satisfaction between three generations. Likewise, Kowske et al. (2010), by applying a cross-classified hierarchical linear modelling to separate the influence of cohort (i.e., generation) from age and time-period effects, found that there was little support for the notion of differences in job satisfaction and turnover intentions between generations. Overall, there is limited empirical support for the hypothesis of specific differences in work-related attitudes and results between generations as well as the reasons for them (Costanza et al., 2012). Taken together, these criticisms caution against overly simplistic understandings of the impact of generational membership on work-related attitudes.

\subsection{Generational Differences and Leadership}

Although the concept of "generations" was introduced by sociologists, it has since found its way into theory and research in other fields, including management and organization studies (e.g., Smola \& Sutton, 2002; Arsenault, 2004; Joshi, Dencker \& Franz, 2011; Ahn \& Ettner, 2014). Management researchers have devoted much attention to exploring generational differences in work-related attitudes and values. Because business leaders want to successfully lead multiple generations of employees in their organizations, scholars believe that understanding generational differences is important for managers and organizations (Smola \& Sutton, 2002). For example, Chen and Choi (2008) used crosssectional surveys to examine differences in work values (e.g., professional growth, personal growth, and work environment) between three generations of workers in the hospitality industry. They found that Baby Boomers rated individual growth higher than the younger generations, while Generation Y paid relatively less attention to personal growth, and more attention to economic returns. Wilson et al., (2008) studied how components of job satisfaction differ across generations: their results indicated that generational cohorts indeed differed in their satisfaction with rewards, scheduling, and professional opportunities etc.

Within the field of management, one sub-area where research on generational differences has grown significantly in recent times is leadership. Theorists have proposed 
various ideas about how generations influence leadership processes and outcomes, and have sought to develop theoretical frameworks regarding the impact of generational membership on different aspects of leadership (e.g., Arsenault, 2004; Farag et al., 2009; Ahn \& Ettner, 2014; Anderson et al., 2017). Farag et al., (2009) used a cross-sectional survey to study the generational differences of nurses, and found generational differences in perceived leadership styles (e.g., transformational leadership and transactional leadership), but no differences in perception of workplace climate (e.g., warmth and belonging). In addition, Clarke's (2014) findings indicate that the relationship between perceived leadership styles and satisfaction with the leader is not the same among generations, stemming from generational differences in perception of leadership and work style preferences. Zemke et al. (2000) claimed that each generation's differences in attitudes, values, and beliefs affects their view of leadership. The typical underlying argument is that, consistent with the theory of generations described above, there are generational differences in leadership processes and outcomes, as well as leadership preferences.

\subsubsection{Generational Differences in Leadership Preferences}

In terms of employees' leadership preferences specifically, scholars have studied the link between generations and leadership preferences for quite some time. Continued exploration of this issue is important not only for academics to deepen theoretical understanding of the impact of generational membership on leadership preferences, but also from a more practical standpoint, as business leaders and managers confront the challenge of attempting to understand, motivate and successfully lead workforces comprised of multiple generations (Smola \& Sutton, 2002). As Smola and Sutton (2002) stated, "as we enter the new millennium and face the entrance of another generation of workers into the changing world of work, managers are encouraged to deal with the generational differences that appear to exist among workers" (p. 363).

Researchers have argued that generational differences in terms of attitudes and perceptions in the workplace, as well as life more generally, could lead to different leadership preferences between generations. For example, Arsenault (2004) surveyed participants about what social memory (i.e., national events, movies, TV shows, music, leaders) seemed important to them, in order to develop a more comprehensive picture of generations' emotions, attitudes, and preferences. The results of Arsenault, (2004) are particularly intriguing in this respect, in that they show that each generation has a different collective memory. Through events, movies, TV shows, music, and famous leaders of their time, each 
generation has its own unique set of leadership preferences. For Baby Boomers and Generation Xers, however, their responses were related to a lot of similar events, movies, TV shows, music and leaders that occurred or became popular in the early stages of growth (Arsenault, 2004).

In terms of leadership attributes, generational cohorts seem to differ in the leadership attributes they consider important, at least to some extent (Sessa et al., 2007). The results of Arsenault's (2004) study reveal that older generations are more likely to believe that honesty is an absolute imperative in leadership, and that leaders must view followers as more than employees (i.e., friends), while Millennials are more likely than older generations to prefer that leaders have the determination to achieve goals and ambitions. Arsenault (2004) also found that younger generations prefer the leader who could challenge the system and create change, while older generations were more like to accept authority and hierarchical leadership. Dulin (2008) also identified that competency, determination, and honesty were the top three attributes that Millennials look for in leaders. Dulin's (2008) findings further suggest that Millennials may prefer a transformational leadership style. Chou (2012) summarized that Millennials manifest a higher need for trust and support from their leaders and organizations, while Huff (2006) reported that younger generations, and especially Millennials, prefer their leaders to provide avenues for self-development. Likewise, Sessa et al., (2007) stated that leaders should be supportive of Millennials, and Lyons and Kuron (2014) summarised (based on a review of relevant literature) that the younger generation seems to be looking for leaders who provide a work environment that is conducive to personal accomplishment, rather than leaders who focus on tasks and organizational success.

However, as with the idea of generational differences generally, there are also criticisms of the idea of generational differences in leadership preferences specifically. Rudolph, Rauvola and Zacher (2018) explain that relatively few empirical studies have explored generations and leadership in depth, and provided sufficient evidences to support the conventional view of generational differences in leadership field. They suggested that most literature suggesting the existence of generational differences in leadership phenomena has been based on little more than assumptions and conjecture. However, as mentioned in the previous section, this assumption is flawed. The literature of generational differences in leadership preferences suggests that the differences in preferred leadership are the reflection of generational differences in values and attitudes (Lyons \& Kuron, 2014). However, the theoretical justification supporting the generational differences in leadership preferences is limited (Lyons \& Kuron, 2014). The results of the empirical research regarding generational 
differences in leadership preferences have not provided a very comprehensive picture of how generations affect people's leadership preferences (Parry \& Urwin, 2011; Rudolph, Rauvola \& Zacher, 2018).

In addition, other empirical research has provided mixed and inconclusive results regarding the existence of generational differences in leadership preferences (Parry \& Urwin, 2011). Many empirical studies, for instance, have found not only differences but also similarities between generations. For example, Wieck et al. (2002) asked nursing student and managers from different generations (i.e., Twenty-Something generation vs. Baby Boomers) to rank the traits of leaders based on their preference, so as to examine generational differences in leadership preferences. The results indicated a high degree of agreement between the generational groups regarding their desired and undesired leadership traits (i.e., both groups valued honesty, supportiveness, and good communication). Likewise, Sessa et al. (2007) found that the rankings of preferred leadership attributes and behaviours among six generations (i.e., Matures, Early Baby Boomers, Late Baby Boomers, Early Gen X, Late Gen $\mathrm{X}$, and Millennials) are relatively similar overall, whilst also showing some differences, such as millennials valued dedication and optimism more than older generations. They found that all generations valued honesty, administrative skill and helping others. Similarly, Arsenault (2004) used a mixed-methods approach to examine leadership preferences across four generational groups (i.e., Veterans, Baby Boomers, Xers, and Nexters), and found both differences across generations, as well as many similarities (i.e., the attributes of honesty, loyalty and competence of different generations were ranked as more-or-less equivalent in importance across the generations). Taken together, these empirical studies regarding generational differences in leadership preferences suggest that the similarities and differences in leadership preferences across generations coexist, which also reminds us not to fall into the aforementioned "cohort trap" (i.e., assuming only differences in leadership preferences between different generations) (Walker, 1993). Thus, as Rudolph, Rauvola and Zacher (2018) suggest, much remains unknown and uncertain about the relationship between generations and leadership preferences.

\subsection{Leadership Preferences}

So far, I have discussed the concept of leadership preferences with little reflection on the precise nature of this concept. A variety of theories exist that aim to map people's leadership preferences, and I explore some of these theories in the following sub-sections. 


\subsubsection{Transformational/Transactional Leadership}

One of the most commonly studied leadership theories is transformational and transactional leadership theory (Lisbon, 2010). As an important part of the full range leadership model, transformational leadership refers to the leadership in which the leader works with the team to determine the required changes, creates a vision to simulate and guide the change (Odumeru \& Ogbonna, 2013). Transactional leadership focuses on the role of supervision, organization, and team performance, which refers to leadership that pays attention to organize the group through rewards and punishment (Odumeru \& Ogbonna, 2013). Transformational and transactional leadership has perhaps been the most used framework for studying leadership preferences in the past two decades (Fukushige \& Spicer, 2007). Much evidence supports the claim that, generally speaking, more people prefer transformational leadership than transactional leadership (Brain \& Lewis, 2004; Fukushige \& Spicer, 2007). Additionally, the results of Dulin (2008) suggest that Millennials' have more of a preference for transformational rather than transactional leadership relative to previous generations. However, most empirical studies considering the transformational/transactional leadership using the multifactor leadership questionnaire (MLQ) were undertaken in Western countries (Avolio et al., 1999; Fukushige \& Spicer, 2007), and work exploring transformational/transactional leadership preferences in other cultural contexts is limited (Fukushige \& Spicer, 2007).

\subsubsection{Implicit Leadership Theory}

Implicit leadership theory (ILT) is an emerging leadership theory. ILT refers to the investigation of follower's view of what constitutes outstanding/ideal leadership (Forsyth, 2018). ILT suggests that the starting point for understanding leadership from a follower's perspective is to understand their psychological leadership prototypes (Phillips \& Lord, 1986; Lin \& Sun, 2018), which represent followers' assumptions about what constitutes an outstanding leader (and thus, outstanding leadership). Followers' evaluation of leadership is based on their own ILT: the more a potential leader (or observed leadership style) matches their ILT, the more likely they are to be recognized as a good leader. Congruence between followers' ILTs and their leader's leadership style also results in better quality of leadermember exchanges, higher follower job satisfaction, and enhanced well-being (Phillips \& Lord, 1986; Epitropaki \& Martin, 2005).

The best predictor of a follower's preference for a particular leadership style should be their conceptualization of their ideal leader (Phillips \& Lord, 1986). In other words, the 
similarities between the follower's ILT and an observed leadership style will prompt the followers to make the following judgments: to what extent the leader is outstanding, to what extent is the leader likable, and whether he/she is willing to be led by or work with that leader (Phillips \& Lord, 1986; Ehrhart, 2012). Therefore, although these two concepts, ILTs and leadership preferences, are distinct, followers' ILTs are closely related to followers' preferences for leadership (Ehrhart, 2012). There are many factors that shape people's implicit leadership prototypes, such as macro cultural characteristics, organizational environments, and micro follower characteristics (e.g., personality traits, identities) (Oc, 2018; Junker and van Dick, 2014). As a consequence, personal leadership preferences have both shared and individual components. However, existing research is still insufficient to study what factors can explain a person's leadership preferences (Lin \& Sun, 2018).

\subsubsection{Culturally Endorsed Leadership Theory}

ILTs not only vary between individuals but also across cultures. In other words, culture plays an important role in the specific content of leadership expectations (Oc, 2018). As stated by Javidan et al. (2006), since people of different cultures tend to hold different ILTs, their basic beliefs about becoming a good leader seem to be naturally different across cultures. More recently, from the perspective of leadership attributes and their relationship to societal culture, the GLOBE (Global Leadership \& Organizational Behavior Effectiveness) study extended implicit leadership theory (ILT) to the level of national culture, which is called culturally endorsed leadership theory (CLT) (House et al., 2004). It incorporates both ILTs and Hofstede's cultural dimensions. The GLOBE study extends ILT to include individuals with common cultural groups or clusters, and convincing evidence from the GLOBE study showed that these individuals maintain relatively stable, common beliefs about leadership (Javidan et al., 2006).

\subsubsection{The GLOBE Study of Leadership}

House et al. (2004) led the GLOBE project study, which spanned about a decade, and covered 62 societies around the world. The GLOBE research team defines leadership as the ability to personally influence, motivate and enable others to contribute to the effectiveness and success of participating in their organization (House et al., 2004). In order to analyze the relationship between leadership and culture, the GLOBE study correlated the response from the leadership group with those from the cultural group. The findings of GLOBE research linked national culture, social effectiveness and organizational leadership on a global scale, and contributed to the organizational behaviour and leadership literature. 
The GLOBE study used clusters to divide cultural groups and promoted the theoretical development of the cross-cultural research field by applying clusters' scores in terms of cultural value, practices, and implicit leadership theory. The study identified and developed nine dimensions of societal culture. It also designed a questionnaire with 112 leader characteristics and behaviours to measure people's leadership understanding, and then, after analysis, identified 21 primary leadership dimensions and 6 global leadership dimensions (i.e., charismatic/value-based leadership; team-oriented leadership; participative leadership; humane-oriented leadership; autonomous leadership; self-protective leadership) based on 21 primary dimensions.

Overall, the GLOBE study measured and validated the scores of each cluster according to nine culture dimensions. In addition, from the perspective of leadership attributes and its relationship to societal culture, the GLOBE study identified 21 primary and 6 global leadership dimensions. From these, it built the endorsed leadership profiles of 10 culture clusters, which promoted the development of culturally implicit leadership theory. It also identified the three attributes of leadership as (1) universally desirable, (2) universally undesirable, and (3) culturally contingent. In terms of the relationship between leadership and culture, the study identified that culture dimensions can best predict leadership dimensions.

\subsection{Generational Differences and Leadership Preferences in China}

As stated by Fukushige and Spicer (2007), most empirical studies considering preferences for transformational versus transactional leadership have been undertaken in Western countries, and work exploring this issue in other cultural contexts is limited. The same observation can be made not only about research on preferences for transformational/transactional leadership, but research on leadership preferences generally (Lin \& Sun, 2018), including the more specific issue of generational differences in leadership preferences. Perhaps the most obvious cultural context that has been understudied in this respect, particularly given its sizable population and influence on global society and economies, is China.

\subsubsection{Generations in China: Millennials vs. Non-Millennials}

Before exploring research on generational differences in leadership preferences in China, a brief outline of Chinese generations is necessary. Generations in China are commonly labelled by birth decade, such as 'Born in the 1960s', 'Born in the 1970s' and so on (Yi et al. 2015). As shown by Sun and Wang (2010), the Chinese generation after 1949 
were categorized as "Boomers" (born from 1940s to 1960s), "Generation X" (born from 1960s to 1979), and "Generation Y" (born between 1980s and 1990s). As mentioned earlier, contextual events can become part of a person's identity, and also influence the attitudes, perceptions and mindset of people born in that period of time (Yi et al., 2010). Yi et al. (2010) distinguish between three living Chinese generations by taking into account major social changes: The Cultural Revolution generation (born 1961-1966), the Social Reform generation (born 1967-1976), the Economic Reform generation (born around 1978) and Millennials (born after 1980 to the 1990s). The Cultural Revolution generation was born in the 1960s and experienced the Cultural Revolution (1966-1976) and, often, extreme poverty (Yi et al., 2010). The Social Reform generation was born in the 1970s and was influenced by dramatic social reform after cultural revolution in their youth. The Economic Reform generations was born around 1978 and experienced the economic reform in China started from 1978, while the Millennial generation has also been labelled the 'One Child Generation' due to the One Child Policy which was launched by the Chinese government in 1980 (Yi et al., 2010). The One Child Policy was a nationwide programme that aimed to limit Chinese families to one child (the programme ceased in 2016). However, the term Millennial is generally used to refer to a person who was born between the 1980s and the early 2000s. The Millennial generation is also sometimes called Generation $\mathrm{Y}$ and is presumed to be a group that has been heavily affected by digital technologies (Yi et al., 2015).

Whilst acknowledging the various ways of categorizing and dividing generations in China described above, in this study, I focus on two broad categories of Chinese generations: Millennials and non-Millennials. According to Zemke et al. (2000), Arsenault (2004), as well as Yi et al. (2015), Millennials (i.e., Generation Y) were born between 1980 and 2000. Thus, for the purposes of this study I adopted their definition of Millennials and defined them as people born between 1980 and 2000, and non-Millennials as people born prior to 1980. The primary reason for this is that it is widely believed that Chinese Millennials are a rather unique social group compared with the older generations of Chinese, not only because of the influence of the One Child Policy, but also because of China's opening up to the world and subsequent socioeconomic development, as well as the impact of globalization process and worldwide changes (i.e., gender equality movement, LGBT rights movement) (Zhao, 2018). As stated by Yi et al. (2010), the One Child Policy was a significant and unique social change in China, and one that has most impacted the characteristics and personality of those born in the wake of this policy - Chinese Millennials (or the so-called 'One Child Generation'). In contrast to previous generations, Millennials are sometimes described in negative terms by 
members of older generations in China. The media has labelled Chinese Millennials "selfcentred", "anti-traditional" and "irresponsible", whilst also noting that they have higher selfconfidence (Li, 2015). Furthermore, since Chinese Millennials are usually the only child in their families, and thus, the centre of their parents' efforts and attention, a possible negative work-related characteristic might be a lack of cooperation and social abilities (Yi et al., 2010). In addition, since China's economic reform and opening up to the world in 1979, the introduction of Western cultural artefacts and practices (e.g., Hollywood movies, American popular music) has continuously challenged China's traditional values, particularly amongst Millennials (Ren et al., 2018). In contrast to the conservative attitude of previous generations, Millennials have received higher education, grew up in the digital age (Tapscott 2008), and have experienced the integration of Eastern and Western cultures through the internet, and travel and education, and thus have a broader vision of world (Zhao, 2018).

\subsubsection{The Psychology of Chinese Millennials}

As the number of Chinese workers in the Millennial generation continues to increase, research on the psychology (and associated behavioural patterns) of Chinese Millennial employees has also grown . Zhao (2018) found that Chinese Millennial employees are eager to prove their abilities, and express their belief that they are responsible and fast learners, and their desire to be heard and accepted. Differences between Millennials and previous generations in work-related attitudes have drawn much attention, with researchers suggesting that Chinese Millennials hold different attitudes, beliefs and aspirations, and also behave differently compared to previous generations (Chou, 2012; Zhao, 2018). For instance, Chen and Lian (2015) examined the generational differences in Chinese employees' work values with 1,015 Chinese employees across three generations (i.e., Cultural Revolution generation; Transitional generation; Millennial generation). They found that generational differences in work values did exist across generations in China. Compared with the two other generations, the Millennial generation placed more importance on both intrinsic (i.e., intangible) and extrinsic (i.e., tangible) rewards, and the Cultural Revolution generation paid more attention to altruism than did the younger generations. Likewise, Yang, Yu and $\mathrm{Wu}$ (2018) found some generational differences in work values in China. Specifically, Millennials in their study showed the highest preferences for both intrinsic (e.g., confidence, personal worth, responsibility, etc.) and extrinsic (e.g., pay, status, promotion and advancement, etc.) work values. However, they also found some important similarities (i.e., the preference for job 
security) between the younger (i.e., Millennials) and older generations (i.e., Cultural Revolution \& Social Reform).

In addition, after surveying 2,350 Chinese respondents, Sun and Wang (2010) identified that younger Chinese have moved to modern values (individualism and secular orientation) and away from traditional values (collectivism and ideology orientation). They also found that younger Chinese are more individualistic and more likely to value selfdevelopment as an important life goal relative to previous generations. The findings of $\mathrm{Yi}$ et al. (2010) not only support those of Sun and Wang (2010), who found younger Chinese have become more individualistic, but also support the idea that younger Chinese are more future oriented and focused on their own planning and goals. However, due to the impact of a strong traditional culture in China, generational differences in work-related perceptions in the US are generally larger than the differences observed in China (Yi et al., 2015). The main finding of Yi et al. (2010) is that while younger generations in China endorse Western-style values and behaviours, they also still maintain many of the same traditional values as older generations, such as loyalty, honesty, caring, etc., and that these traditional values still influence their attitudes and conduct in the workplace.

\subsubsection{General and Generation-Specific Leadership Preferences in China}

Some researchers have also studied Chinese leadership preferences and their differences from and similarities to the preferences of other (mainly Western) cultural groups. Confucianism has influenced China for thousands of years since its origin. Confucianism is therefore said to be the core of Chinese philosophy, such that its impact on Chinese life and traditions is very deep. For example, in Ling et al.'s (2000) study of Chinese implicit leadership theory, interpersonal competence was rated highest among all age groups (i.e., $<25,26-35,36-45,46-55,>55)$ reflecting the importance of this factor, which is consistent with traditional Chinese collectivist values. Likewise, Koehn (2001) examined the Confucian concept of trustworthiness and the business practice of trustworthiness in China, and then found that Confucian values also have an impact on people's evaluation of a leader in modern times. For example, the emphasis on trustworthiness makes people pay much attention to the virtue (i.e., trustworthiness, honesty, kindness, etc.) of the leader (Koehn, 2001). In addition, the rationality and high receptivity of authoritarian leadership by Chinese people stems from the traditional ethical relationship regulated by Confucianism in China (Farh \& Cheng, 2000). Confucianism prescribes a clear hierarchy of authority in society (i.e., emperor, father, husband): all members of society should obey the emperor, and all other family members 
should obey the father and/or grandfather in a family (Yen, 2015). Taken together, the leadership preferences of Chinese people may have been influenced by traditional culture (i.e., Confucianism).

Research has found that Chinese people desire leaders that avoid abusing their power, remain selfless, and become a role model for their followers. According to Farh and Cheng (2000), Wong (2001), as well as Lin and Sun (2018), this expectation of moral leadership stems from the Confucian tradition. Two virtues are particularly valued in the Chinese context: selflessness and leading by example (Farh \& Cheng 2000). In addition, the research of Lin and Sun (2018) has found that of all known leadership styles, contemporary Chinese employees most favour ethical leadership, and are also accepting of transformational leadership. In addition, the preference for authoritarian leaders depends on the power distance orientation of followers. Research by Lin and Sun (2013) found that Chinese followers' preferences for charismatic leadership and moral leadership were positively related to core self-evaluations, such that the power distance orientation of followers is positively correlated with their preference for authoritarian leadership and negatively correlated with their preference for moral leadership.

Within this research on Chinese people's leadership preferences, studies have also found some differences between the Millennial and non-Millennial generations. Chinese Millennials tend to expect more from their managers (Yi et al., 2010), and demonstrate a preference for more supportive leadership that facilitate decreases in their negative emotions (Jiang \& Hui, 2016). From a follower-centric perspective, Xie and Chen (2014) and Ren et al. (2018) investigated the influence of need for involvement on the leadership preferences of Chinese Millennials. Their research indicated that the need for employment involvement has a negative impact on Chinese Millennial employees' preference for directive and delegating leadership but is positively related to their preference for participative and coaching leadership (Xie \& Chen, 2014; Ren et al., 2018).

However, to date, research on generational differences in employees' leadership preferences in the context of China is still limited (Lin \& Sun, 2018). The research of Yi et al. (2010), while not explicitly focused on generational differences in leadership preferences, is a notable exception. They found significant differences in preferences for only 4 leadership traits (i.e., ambitious, mentor, team player and loyal) among 15 leadership traits between the Cultural Revolution Generation (i.e., born in the 1960s), Social Reform Generation (i.e., born in the 1970s) and Millennials (i.e., born in the 1980s and 1990s). However, their results were rather nuanced. In terms of preferences for the leader attributes of ambitious and mentor, the 
Cultural Revolution Generation showed a stronger preference for ambitious and mentorfocused leadership than both the Social Reform Generation and Millennials; compared with the Millennial generation, the Cultural Revolution Generation preferred leaders to be a team player, but no significant difference were found between Millennials and Social Reform respondents in respect of the team player attribute; in terms of preferences for loyal, Millennials had a lower preference for loyal leadership than Cultural Revolution Generation, but the Social Reform generation was not different from either Millennials or Cultural Revolution. Note, though, that generational differences in leadership preferences were not a core focus of Yi et al.'s (2010) study.

Taken together, although researchers (e.g., Sun \& Wang, 2010; Yi et al., 2010; Chen \& Lian, 2015; Yang, Yu \& Wu, 2018) have attempted to study generational differences in work-related attitudes and values in China, with some directly exploring Chinese Millennials' leadership preferences (e.g., Xie \& Chen, 2014; Jiang \& Hui, 2016; Ren et al., 2018), relatively little research has explored generational differences in leadership preferences of Chinese people, certainly when compared with the volume of research on this issue conducted in Western contexts. Therefore, there are still many uncertainties and unknowns regarding the generational differences in leadership preferences in the context of China. Thus, the guiding research question of the current study was as follows:

In what ways, if at all, do the leadership preferences of Chinese Millennials differ from those of Chinese Non-Millennials? 


\section{CHAPTER THREE: METHODOLOGY}

The purpose of this study was to uncover and compare the leadership preferences of Chinese Millennial and non-Millennial employees, so as to identify any intergenerational differences/similarities. Specifically, I aimed to answer the research question: In what ways, if at all, do the leadership preferences of Chinese Millennials differ from those of Chinese non-Millennials? Given my desire to explore these leadership preferences on a large scale, I used quantitative data collection and analytical approaches. The current study was also exploratory in nature, meaning that I sought to explore the nature of the leadership preferences of Chinese Millennials and non-Millennials, and identify any differences or similarities in their leadership preferences in an open-ended way. As such, I had no specific hypotheses to be tested, but used statistical tests to inductively identify any significant differences in leadership preferences between two generational groups. This chapter provides further details about the methodology of this study, including research and questionnaire design, measurement, sampling, and analysis. I conclude with a brief discussion of relevant ethical considerations.

\subsection{Research Design}

This study attempted to identify any differences in leadership preferences between Chinese Millennials and non-Millennials. I sought insights by collecting_using a questionnaire - and comparing — using statistical analyses - the leadership preferences of Chinese Millennials and non-Millennials employed in full-time work. Charmaz (2014) asserts that "our data collection methods flow from the research question" (p. 27). In order to compare the leadership preferences of two generational groups in China, the most important consideration was being able to assess their leadership preferences and make direct and effective comparisons. Therefore, I chose a quantitative approach because of the ability to score and analyze data in numeric form. In this way, the leadership preferences could be captured in the form of numeric ratings of different leader characteristics and behaviours, which allowed for comparison of the leadership preferences of the two generational groups.

While the data was collected and analyzed quantitatively, it was nevertheless exploratory in nature. Stebbins (2001) asserts that exploratory social research aims to discover how people get along in the relevant environment, the meaning of their behaviour, and other issues related to them. The goal is to learn 'what is happening now' and investigate social phenomena with few a priori expectations. In general, an exploratory methodology 
emphasizes trying to find a theory from the data itself (Stebbins, 2001). Exploratory research is usually conducted when researchers do not have (or have little) existing research and/or theory to draw on (Stebbins, 2001). Considering these features of exploratory research in light of my research question, I decided this methodology was suitable for my research for two reasons. Firstly, and consistent with Stebbins's definition of exploratory research, I aimed to investigate a social phenomenon (i.e., leadership preferences across generations) in a specific environment (i.e., workplaces in China). Second, as explained in literature review, research and theory on generational differences in leadership preferences is limited (Lyons \& Kuron, 2014), especially in the context of China (Lin \& Sun, 2018), with few studies (e.g., Yi et al., 2010) focusing specifically on differences in leadership preferences between the older and younger generations in China. Thus, an exploratory methodology was appropriate given my research question and focus: it allowed me to investigate the phenomenon of interest without explicit expectations (e.g., as represented in a priori hypotheses).

I explored the leadership preferences of a sample of online respondents from each of the two groups - Chinese Millennials and non-Millennials - using a questionnaire. Questionnaires are an effective method for measuring the behaviours, attitudes, preferences, opinions and intentions of a relatively large number of subjects efficiently (McLeod, 2018). Given the time and resource constraints of a Master project, efficiency was an important concern for me. The questions in a survey are standardized, asking all participants exactly the same questions in the same order (McLeod, 2018), making it straightforward to compare information provided by different participants. My research question necessitated the collection of leadership preferences from a large number of Chinese Millennials and nonMillennials, meaning a questionnaire was an appropriate data collection method.

As mentioned in the literature review, for the purposes of this study I define Millennials as people born between 1980 and 2000, and non-Millennials as people born prior to 1980. I used a questionnaire to assess how a sample of people from each of the two groups rated a variety of leader characteristics and behaviours, in terms of the centrality of these LCBs to their conception of outstanding leadership. In this way, I sought to empirically capture and compare the implicit theories of leadership (ITLs) of each generational group, which, as stated in the literature review, are an accurate predictor of leadership preferences. 


\subsection{Questionnaire Design \& Measures}

The questionnaire I used for this study was based on the leadership section of the questionnaire used in the well-known GLOBE (Global Leadership \& Organizational Behavior Effectiveness) research project. The leadership component of the GLOBE project was based on a questionnaire comprised of 112 leader characteristics and behaviours, which aimed to measure people's understanding of what made for an outstanding leader. By the end of the GLOBE project, more than 17,000 participants from 62 societies had contributed data. Since the current study focused on the Chinese context, where the GLOBE questionnaire had previously been used and validated, the leadership portion of the GLOBE questionnaire was suited to answering my research question.

Since the original GLOBE questionnaire was in English, I translated the items I used from it into Chinese by referring to various translation platforms and software (e.g., Google Translate; Youdao Translate; Baidu Translate). I synthesized the translations given by these different sources to achieve the most logical and fluent Chinese version. English and Chinese copies of the final questionnaire I used are provided in Appendix D and E, respectively.

The questionnaire I used in the present study asked participants to rate 55 leader characteristics and behaviours (LCBs) selected from the 112 LCBs in the original GLOBE questionnaire, in terms of how essential the participant believed each LCBs was to outstanding leadership. These 55 LCBs included the characteristics of honest, bossy, positive, evasive, diplomatic, intra-group competitor, mediator, etc. Considering the potential for participants to become fatigued by overly long questionnaires, I only used half of the GLOBE LCBs in my questionnaire. I achieved this by eliminating LCBs that, when translated into Chinese, had a very similar meaning to another LCB (e.g., rather than including bossy and tyrannical, I only included bossy) and only one term from pairs of antonyms (e.g., honest vs. dishonest; collaborative vs. non-cooperative). In addition, I omitted those LCBs that did not have a clear conceptual equivalent in Chinese from my questionnaire. For example, the definition of the English word willful is strong-willed, determined, resolute and persistent (i.e., willful = strong-willed, determined, resolute and persistent). The Chinese translation of 'willful' is '执拗的', which is a derogatory term. However, the Chinese translation of every word in the definition is commendatory, which may confuse participants and subsequently affect understanding and judgement.

Participants were asked to numerically rate each of the 55 LCBs in terms of how important they personally believed that specific behaviour or characteristic was for a leader to 
be "outstanding". The measurement scale used was 1 to 7: 1 (greatly inhibits); 2 (somewhat inhibits); 3 (slightly inhibits); 4 (has no impact); 5 (contributes slightly); 6 (contributes somewhat); 7 (contributes greatly). In this study, the leadership preferences of Chinese Millennial and non-Millennial participants were compared using the mean rating scores of these LCBs for each group. As for the measurement of generational groups, the generations were divided according to the age of participants. Of note, age was operationalized in the questionnaire as a categorical variable with five levels (i.e., younger than $25 ; 26$ to $35 ; 35$ to $40 ; 41$ to 45; older than 45). In the case of a large age range, as I anticipated would occur in my study, age categorization can show the age distribution of participants more clearly and concisely. In addition, I considered that treating age categorically would allow me to use an ANOVA in the data analysis stage, given that the premise of this analysis is that the independent variable should be categorical and independent groups (McCrum-Gardner, 2008).

\subsection{Sampling}

Patton (2002) recommends purposeful sampling, considering that researchers need to find participants who best meet the objectives of any given study. Thus, the sampling rationale I adopted was purposive at the population level, as there were specific sampling parameters I was interested in (i.e., full-time employees in China with at least one year work experience from two generational groups). To be related to the research questions, the sample was drawn from the Chinese Millennial population and non-Millennial population, and all participants were born in mainland China and lived in mainland China at the time of the study. Although the Millennial group included those born between the 1980s to the early 2000s, in this study, only those cohort members who had been working full-time for at least one year were surveyed for two reasons. First, part-time employees may not have as much contact with leaders in the workplace as full-time employees. Second, those who have retired or are in the process of transitioning out of work (e.g., by undertaking part-time work) may not be familiar with the current general workplace environment and leadership. Participants with at least one year of work experience were selected because too little work experience may affect the perception and judgment of leadership. In general, a person who has met the legal working age in China (18 years old) and has worked full-time for at least a year is at least 19 years old (born in 2000). Therefore, the Millennial participants were drawn from those who were born between 1980 to 2000. The non-Millennial group included individuals 
born before 1980 who were still employed full-time. As this study focused on potential generational differences in leadership preferences at work, the key variables of interest were generation, occupational status (full-time), and work experience (at least 1 year). However, within each sub-group, I applied no specific parameters to sampling and participant recruitment (e.g., I was not concerned about the geographic region of China participants lived in, or the industry or type of companies they worked in).

Participants were recruited using an online participant recruitment platform, Wenjuanxing - a Chinese equivalent of the widely-used Amazon Mechanical Turk platform. Wenjuanxing is a platform website that provides professional online questionnaire survey, voting, testing, and comments. It provides a series of services for online questionnaire design, data collection, customized forms, and survey analysis. In addition, users of the platform can receive both financial and non-financial rewards (e.g., examples of nonfinancial rewards) for participating in surveys. An invitation to complete the questionnaire was sent to registered users of Wenjuanxing who met the sampling criteria detailed above, along with a link to the survey itself. Since I paid for the sample service and did not personally send out the questionnaire to participants, Wenjuanxing did not provide the exact number of the questionnaires sent out, meaning I could not assess response rates. I only knew the exact number of respondents that eventually completed the survey. Wenjuanxing agreed to send follow-up reminders and promised to increase the number of surveys sent out if the desired number of respondents was not reached.

In order to determine an appropriate sample size for this study, the determination of statistical power and estimated effect size was considered in advance. The statistical power is proportional to the sample size, and the larger the effect size, the greater the power (Cohen, 1992). According to Cohen (1992), the common practice is to use an effect size of .5 as it represents a medium effect size (Cohen,1992). Thus, the medium effect size was acceptable for this study and was used in the sample size determination. In addition, statistical power at the level of .80 is a convention for general use (Cohen, 1992). Typically a statistical power of .80 can avoid the risk of a Type II error without exceeding the investigator's resources (Cohen, 1992). Thus, taken a medium effect size of .5 and a generally accepted power of .80, the necessary sample size for each group is 64 (Cohen, 1992), when the significance level is .05. Furthermore, Cohen (1992) also stated that if researchers have enough resources to obtain a larger sample size, they can increase their statistical power by increasing the sample size. Therefore, considering the greater statistical power level, effect size, and the resources available, I set the sample size to a total of 450 to 500 . Ultimately, a total of 545 
questionnaires were completed, 460 of which were valid (the rest contained missing data). 230 of these usable questionnaires were from Millennial participants, while the other 230 were from non-Millennial participants. The age of Chinese Millennial participants ranged from 18 to 40, whilst non-Millennial participants were all over 40 years old.

\subsection{Data Analysis}

The data analysis was conducted using the SPSS software. Descriptive statistics were calculated for the samples (age, gender, and education level) as were the two generational groups' mean ratings of each of the 55 LCBs. This allowed me to identify differences and similarities in ratings of LCBs between the two groups. As I wanted to determine if Chinese Millennials' mean ratings of any LCBs were significantly different from the non-Millennial group's mean ratings of the LCBs, I conducted an independent samples t-test between the Millennials' and non-Millennials' mean ratings of each of the LCBs. The independent sample t-test is used to compare the means of two independent groups to determine whether there is statistical evidence that the means in two unrelated groups are significantly different (McCrum-Gardner, 2008).

In addition, as a follow-up analysis intended to identify any differences between more specific sub-groups within each generation, I conducted an age-based, one-way ANOVA to assess if significant differences existed on any of the mean rating scores of the 55 LCBs among the five different age groups ${ }^{1}$ (i.e., younger than $25 ; 26$ to $35 ; 35$ to $40 ; 41$ to 45 ; older than 45). One-way ANOVA can be used to determine whether there are statistically significant differences between the means of more than two independent groups (McCrumGardner, 2008). I also conducted an independent samples t-test between the youngest and oldest age groups to identify any significant differences on the mean rating scores of 55 LCBs between the youngest Millennials (i.e., those younger than 25) and the oldest nonMillennials (i.e., those older than 45). I did this with the view that if any generational differences in leadership preferences did exist, they would be most apparent between these two sub-groups of the overall sample.

Figure 3.1 summarizes what steps were followed in this study to analyze data and arrive at final results. For research purposes, a significance level of .05 was adopted for this study. The level $\alpha=.05$ was used for analysis, as this parameter is the most commonly specified value in social science research (Lipsey, 1990).

\footnotetext{
${ }^{1}$ As mentioned earlier, age was operationalized as a categorial variable with five levels in this study
} 


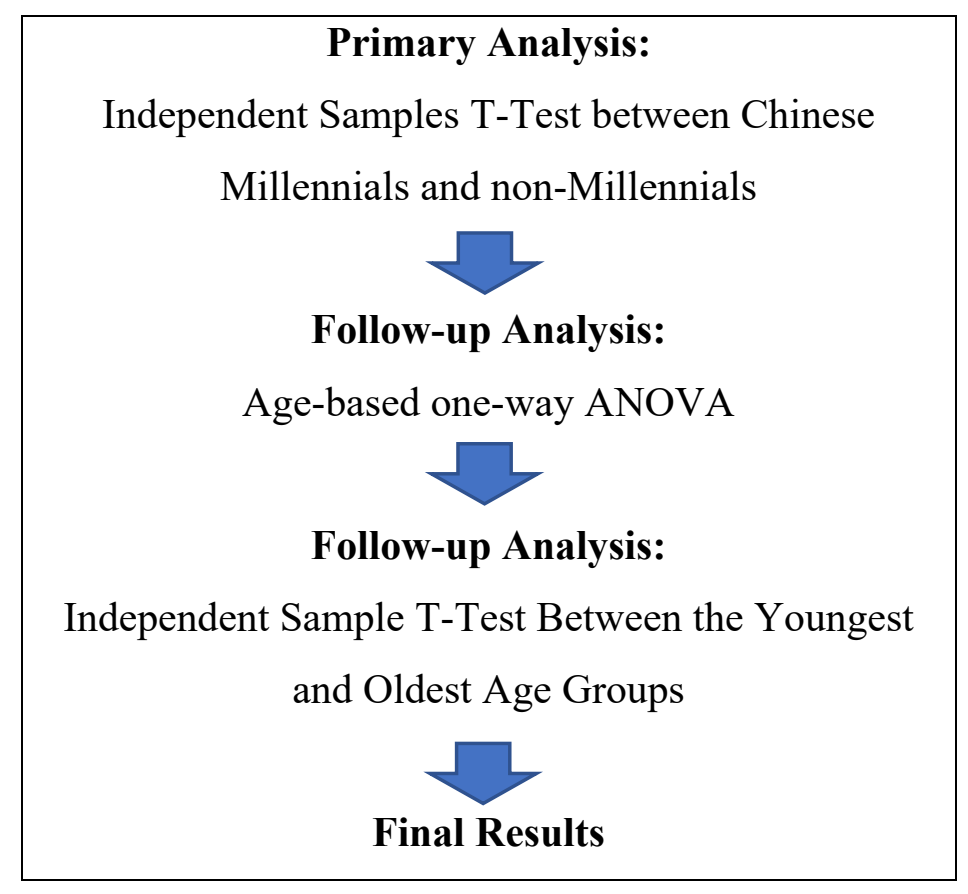

Figure 1 - Data Analysis Procedure

\subsection{Ethical Considerations}

Participation in this study was voluntary and anonymous to individuals. Participants were informed that they could withdraw from the study at any time with no penalty, and the questionnaire would not ask for any information that would make them personally identifiable, including their name and company name. In addition, the data collected was held securely on a university server. Participants could not be identified from any of their responses. Note also that this research was approved by the Human Ethics Committee of Victoria University of Wellington prior to commencing participant recruitment. 


\section{CHAPTER FOUR: RESULTS}

In order to identify any differences/similarities between the leadership preferences of Chinese Millennials and non-Millennials, a direct comparison of the mean rating scores of LCBs between the two generational groups, and the comprehensive analysis (i.e., independent samples t-test and ANOVA) were conducted. The results of these analyses are presented in this chapter. I begin by detailing the demographic characteristics of participants. I then present the primary analysis, which was an independent samples t-test to compare the leadership preferences between Chinese Millennials and non-millennials. Then, I introduce the results of two follow-up analyses, including an age-based one-way ANOVA to compare the leadership preferences of the five age groups, and another independent samples t-test to compare the leadership preferences between the youngest and oldest age group. I conclude by summarizing the key results of the questionnaire.

\subsection{Descriptive Statistics}

Table 1 reports the distribution of age, gender and education level for the participants in this study. A total of 460 valid questionnaire responses were used in the analysis, including 230 Millennial and 230 non-Millennial participants. Most Millennials (30.9\%) were in the 26-35 age group, with a relatively similar number of remaining millennials falling in the $<25$ age group (8.7\%) and 36-40 age group (10.4\%). Non-Millennials in the 41-45 age group accounted for $22.4 \%$, and the $>45$ age group accounted for $27.6 \%$. A total of 235 males and 225 females participated the study (99 males and 131 females in the Millennial group, 136 males and 94 females in the non-Millennial group).

\section{Table 1}

Demographic Characteristics of Participants

\begin{tabular}{lcccccc}
\hline & \multicolumn{2}{c}{ Millennials } & \multicolumn{2}{c}{ Non-Millennials } & \multicolumn{2}{c}{ Full sample } \\
\cline { 2 - 7 } & $\mathrm{n}$ & $\%$ & $\mathrm{n}$ & $\%$ & $\mathrm{n}$ & $\%$ \\
\hline Gender & 99 & 43 & 136 & 59.1 & 235 & 51.1 \\
$\quad$ Male & 131 & 57 & 94 & 40.9 & 225 & 48.9 \\
Female & & & & & 40 & 8.7 \\
Age & 40 & 17.4 & - & - & 142 & 30.9 \\
$<25$ & 142 & 61.7 & - & - & 48 & 10.4 \\
$26-35$ & 48 & 20.9 & - & - & 103 & 22.4 \\
$36-40$ & - & - & 103 & 44.8 & 127 & 27.6 \\
$41-45$ & - & - & 127 & 55.2 & & \\
$>45$ & & & & & 39 & 8.5 \\
Education & 8 & 3.5 & 31 & 13.6 & & \\
$\quad$ High school & & & & & & \\
\hline
\end{tabular}




\begin{tabular}{lcccccc}
\hline College & 31 & 13.5 & 70 & 30.4 & 101 & 22 \\
Bachelor & 162 & 70.4 & 122 & 53 & 284 & 61.7 \\
Master and higher & 29 & 12.6 & 7 & 3 & 36 & 7.8 \\
\hline
\end{tabular}

Table 2 shows the mean ratings of the 55 leader characteristics and behaviours (LCBs) for Chinese Millennial and non-Millennial participants, sorted by the difference in means between the two generation groups (largest differences at the top to smallest at the bottom). A simple comparison of the mean rating scores for each LCBs for Chinese Millennials and non-Millennials shows that there were many similarities in the responses of the two generational groups. The biggest difference in mean ratings between the two groups of means was 0.36 (bossy), followed by 0.34 (non-explicit), while the smallest difference is 0 (positive, enthusiastic, communicative). Overall, there were no differences in means greater than 0.4 .

In addition, some of the characteristics were in similar relative ranking positions across the generations. Table 3 shows the top 10 highest rated LCBs and the 10 lowest rated LCBs for Millennials and non-Millennials. For both Millennials and non-Millennials, the characteristics of self-interested, tender, egocentric and secretive rated the lowest.

Furthermore, across the two groups, five of the six highest-rated leader characteristics were the same (trustworthy, administratively skilled, team builder, inspirational and honest). These results suggest that both Millennials and non-Millennials are equally likely to believe that the attributes of trustworthy, administratively skilled, team builder, inspirational and honest are essential features of outstanding leadership, but that self-interested, tender, egocentric and secretive may inhibit leader effectiveness. Overall, then, Chinese Millennials and non-Millennials seem to hold similar conceptions of what constitutes both the ideal and the prototypically poor leader. 
Table 2

Mean Ratings of 55 LCBs - Chinese Non-Millennials vs. Chinese Millennials

\begin{tabular}{|c|c|c|c|}
\hline & $\begin{array}{l}\text { Means for Non- } \\
\text { Millennials }\end{array}$ & Means for Millennials & $\begin{array}{c}\text { Differences } \\
\text { Between Means }\end{array}$ \\
\hline Bossy & 2.90 & 2.54 & 0.36 \\
\hline Non-explicit & 2.92 & 2.58 & 0.34 \\
\hline Micro-manager & 4.07 & 4.34 & 0.27 \\
\hline Cautious & 3.60 & 3.33 & 0.27 \\
\hline Distant & 2.95 & 2.73 & 0.22 \\
\hline Intra-group conflict avoider & 5.52 & 5.73 & 0.21 \\
\hline Ambitious & 5.64 & 5.85 & 0.21 \\
\hline Procedural & 4.56 & 4.35 & 0.21 \\
\hline Modest & 5.62 & 5.82 & 0.20 \\
\hline Independent & 5.50 & 5.70 & 0.20 \\
\hline Orderly & 6.17 & 6.36 & 0.19 \\
\hline Sensitive & 5.63 & 5.81 & 0.18 \\
\hline Self-sacrificial & 4.96 & 4.78 & 0.17 \\
\hline Inspirational & 6.51 & 6.36 & 0.16 \\
\hline Intra-group competitor & 4.60 & 4.46 & 0.15 \\
\hline Avoids negatives & 3.56 & 3.41 & 0.15 \\
\hline Risk averse & 4.83 & 4.69 & 0.14 \\
\hline Administratively skilled & 6.29 & 6.43 & 0.14 \\
\hline Secretive & 2.56 & 2.41 & 0.14 \\
\hline Compassionate & 5.23 & 5.09 & 0.13 \\
\hline Clear & 5.95 & 6.07 & 0.13 \\
\hline Egocentric & 2.35 & 2.23 & 0.12 \\
\hline Collaborative & 6.04 & 6.16 & 0.12 \\
\hline Informed & 5.98 & 6.10 & 0.12 \\
\hline Logical & 6.21 & 6.32 & 0.11 \\
\hline Self-interested & 1.80 & 1.90 & 0.10 \\
\hline Tender & 2.03 & 1.92 & 0.10 \\
\hline Patient & 5.75 & 5.85 & 0.10 \\
\hline Coordinator & 6.19 & 6.29 & 0.10 \\
\hline Mediator & 5.80 & 5.87 & 0.08 \\
\hline Performance-oriented & 5.03 & 4.99 & 0.05 \\
\hline Improvement-oriented & 5.91 & 5.96 & 0.05 \\
\hline Risk taker & 3.59 & 3.54 & 0.05 \\
\hline Decisive & 6.20 & 6.14 & 0.05 \\
\hline Sincere & 6.04 & 6.00 & 0.04 \\
\hline Encouraging & 6.20 & 6.15 & 0.04 \\
\hline Team builder & 6.45 & 6.41 & 0.04 \\
\hline Win/win problem solver & 6.13 & 6.17 & 0.04 \\
\hline Trustworthy & 6.44 & 6.47 & 0.03 \\
\hline Organized & 5.97 & 6.00 & 0.03 \\
\hline Honest & 6.35 & 6.32 & 0.03 \\
\hline Intelligent & 6.31 & 6.27 & 0.03 \\
\hline Fraternal & 4.85 & 4.83 & 0.03 \\
\hline
\end{tabular}




\begin{tabular}{llll}
\hline Generous & 5.50 & 5.52 & 0.02 \\
Formal & 5.56 & 5.54 & 0.02 \\
Diplomatic & 5.60 & 5.62 & 0.02 \\
Evasive & 4.26 & 4.28 & 0.02 \\
Autocratic & 2.57 & 2.59 & 0.02 \\
Class-conscious & 3.82 & 3.80 & 0.01 \\
Consultative & 5.42 & 5.52 & 0.10 \\
Anticipatory & 5.95 & 5.93 & 0.01 \\
Loyal & 5.77 & 5.76 & 0.01 \\
Positive & 6.28 & 6.28 & 0.00 \\
Enthusiastic & 6.22 & 6.22 & 0.00 \\
Communicative & 6.04 & 6.05 & 0.00 \\
\hline
\end{tabular}

Table 3

The top 10 highest rated LCBs and the 10 lowest rated LCBs for Millennials and nonMillennials

\begin{tabular}{|c|c|c|c|}
\hline \multicolumn{2}{|c|}{ Non-Millennials } & \multicolumn{2}{|c|}{ Millennials } \\
\hline Means & The top 10 highest rated LCBs & Means & The top 10 highest rated LCBs \\
\hline 6.51 & Inspirational & 6.47 & Trustworthy \\
\hline 6.45 & Team builder & 6.43 & Administratively skilled \\
\hline 6.44 & Trustworthy & 6.41 & Team builder \\
\hline 6.35 & Honest & 6.36 & Inspirational \\
\hline 6.31 & Intelligent & 6.36 & orderly \\
\hline 6.29 & Administratively skilled & 6.32 & honest \\
\hline 6.28 & Positive & 6.32 & Logical \\
\hline 6.22 & Enthusiastic & 6.29 & Coordinator \\
\hline 6.21 & Logical & 6.28 & Positive \\
\hline 6.20 & Encouraging & 6.22 & Enthusiastic \\
\hline Means & The 10 lowest rated LCBs & Means & The 10 lowest rated LCBs \\
\hline 3.59 & Risk taker & 3.41 & Avoids negatives \\
\hline 3.56 & Avoids negatives & 3.33 & Cautious \\
\hline 2.95 & Distant & 2.73 & Distant \\
\hline 2.92 & Non-explicit & 2.59 & Autocratic \\
\hline 2.90 & Bossy & 2.58 & Non-explicit \\
\hline 2.57 & Autocratic & 2.54 & Bossy \\
\hline 2.56 & Secretive & 2.41 & Secretive \\
\hline 2.35 & Egocentric & 2.23 & Egocentric \\
\hline 2.03 & Tender & 1.92 & Tender \\
\hline 1.80 & Self-interested & 1.90 & Self-interested \\
\hline
\end{tabular}




\subsection{Primary Analysis: Independent Samples T-Test}

In order to conduct a more robust comparison of the two groups' ratings of the LCBs, I used an independent samples t-test analysis. The independent sample t-test is used to compare the means of two independent groups to determine whether there is statistical evidence that the means in two unrelated groups are significantly different (McCrumGardner, 2008). An independent samples t-test was run on each LCB to determine whether there were significant differences between the Millennials' and non-Millennials' ratings of any of these attributes. A summary of the results is presented in Table 4 (a full list of results is provided in Appendix A). Of the 55 LCBs rated by both groups, significant differences were only found in respect of 8 LCBs: bossy; inspirational; intra-group conflict avoider; orderly; modest; non-explicit; cautious and ambitious.

First, there was a significant difference $(\mathrm{t}(458)=2.647, \mathrm{p}=.008)$ in the mean rating scores for bossy, with Millennials $(\mathrm{M}=2.54, \mathrm{SD}=1.366)$ rating it as more harmful to outstanding leadership than non-Millennials $(\mathrm{M}=2.9, \mathrm{SD}=1.519)$. Second, a significant difference $(\mathrm{t}(458)=2.253, \mathrm{p}=.025)$ was also found in respect of inspirational, with Millennials $(\mathrm{M}=6.36, \mathrm{SD}=.744)$ rating it as less central to outstanding leadership than nonMillennials $(\mathrm{M}=6.51, \mathrm{SD}=.746)$. Third, a significant difference $(\mathrm{t}(458)=-2.231, \mathrm{p}=.026)$ was found in respect of intra-group conflict avoider, with Millennials $(\mathrm{M}=5.73, \mathrm{SD}=.992)$ rating it as more central to outstanding leadership than non-Millennials $(\mathrm{M}=5.52, \mathrm{SD}=$ 1.014). Fourth, there was a significant difference $(\mathrm{t}(458)=-2.33, \mathrm{p}=.02)$ in the mean rating scores for orderly, with Millennials $(\mathrm{M}=6.36, \mathrm{SD}=.822)$ rating it as more central to outstanding leadership than non-Millennials $(\mathrm{M}=6.17, \mathrm{SD}=.897)$. In addition, a significant difference $(\mathrm{t}(435.325)=-2.111, \mathrm{p}=.035)$ was also found in respect of modest, with Millennials $(\mathrm{M}=5.82, \mathrm{SD}=.963)$ rating it as more central to outstanding leadership than non-Millennials $(M=5.62, S D=1.066)$. A significant difference $(\mathrm{t}(458)=2.704, \mathrm{p}=.007)$ was also found in respect of non-explicit, with Millennials $(\mathrm{M}=2.58, \mathrm{SD}=1.274)$ rating it as more harmful to outstanding leadership than non-Millennials $(\mathrm{M}=2.92, \mathrm{SD}=1.412)$. Furthermore, a significant difference $(\mathrm{t}(458)=2.284, \mathrm{p}=.023)$ was also found in respect of cautious, with Millennials $(\mathrm{M}=3.33, \mathrm{SD}=1.345)$ rating it as less central to outstanding leadership than non-Millennials $(\mathrm{M}=3.6, \mathrm{SD}=1.181)$. Finally, a significant difference $(\mathrm{t}(458)=-2.081, \mathrm{p}=.038)$ was found in respect of ambitious, with Millennials $(\mathrm{M}=5.85$, $\mathrm{SD}=1.004)$ rating it as more central to outstanding leadership than non-Millennials $(\mathrm{M}=$ 5.64, $\mathrm{SD}=1.142$ ). However, no significant differences were found between Chinese Millennials' and non-Millennials' ratings of the other 47 LCBs. 
Taken together, these results indicate that of the 55 LCBs assessed, Chinese

Millennials are more likely than non-Millennials to perceive the characteristics of intra-group conflict avoider, orderly, modest and ambitious as critical to leader effectiveness, and the characteristics of bossy, non-explicit and cautious as inhibiting leader effectiveness. Overall, however, these results suggest there are many more similarities (47 out of $55 \mathrm{LCBs}$ ) in leadership preferences than differences ( 8 out of 55 LCBs) between the Millennial and nonMillennial groups.

Table 4

Independent Samples T-Test between Chinese Millennials and non-Millennials (Differences significant at $p<.05$ only, see Appendix A for full results)

\begin{tabular}{|c|c|c|c|c|c|c|c|c|c|c|}
\hline & & \multirow[b]{2}{*}{$\mathrm{F}$} & \multirow[b]{2}{*}{ Sig. } & \multirow[b]{2}{*}{$\mathrm{t}$} & \multirow[b]{2}{*}{ df } & \multirow{2}{*}{$\begin{array}{l}\text { Sig. } \\
(2- \\
\text { tailed) }\end{array}$} & \multirow{2}{*}{$\begin{array}{c}\text { Mean } \\
\text { Difference }\end{array}$} & \multirow{2}{*}{$\begin{array}{l}\text { Std. Error } \\
\text { Difference }\end{array}$} & \multicolumn{2}{|c|}{$\begin{array}{c}95 \% \text { Confidence } \\
\text { Interval of the } \\
\text { Difference }\end{array}$} \\
\hline & & & & & & & & & Lower & Upper \\
\hline \multirow[t]{2}{*}{ Bossy } & $\begin{array}{l}\text { Equal variances } \\
\text { assumed }\end{array}$ & 3.375 & .067 & 2.647 & 458 & .008 & .357 & .135 & .092 & .621 \\
\hline & $\begin{array}{l}\text { Equal variances } \\
\text { not assumed }\end{array}$ & & & 2.647 & 452.879 & .008 & .357 & .135 & .092 & .621 \\
\hline \multirow[t]{2}{*}{ Inspirational } & $\begin{array}{l}\text { Equal variances } \\
\text { assumed }\end{array}$ & .333 & .564 & 2.253 & 458 & .025 & .157 & .069 & .020 & .293 \\
\hline & $\begin{array}{l}\text { Equal variances } \\
\text { not assumed }\end{array}$ & & & 2.253 & 457.997 & .025 & .157 & .069 & .020 & .293 \\
\hline \multirow{2}{*}{$\begin{array}{l}\text { Intra-group } \\
\text { conflict } \\
\text { avoider }\end{array}$} & $\begin{array}{l}\text { Equal variances } \\
\text { assumed }\end{array}$ & .204 & .652 & -2.231 & 458 & .026 & -.209 & .094 & -.392 & -.025 \\
\hline & $\begin{array}{l}\text { Equal variances } \\
\text { not assumed }\end{array}$ & & & -2.231 & 457.780 & .026 & -.209 & .094 & -.392 & -.025 \\
\hline \multirow[t]{2}{*}{ Orderly } & $\begin{array}{l}\text { Equal variances } \\
\text { assumed }\end{array}$ & .713 & .399 & -2.330 & 458 & .020 & -.187 & .080 & -.345 & -.029 \\
\hline & $\begin{array}{l}\text { Equal variances } \\
\text { not assumed }\end{array}$ & & & -2.330 & 454.533 & .020 & -.187 & .080 & -.345 & -.029 \\
\hline \multirow[t]{2}{*}{ Modest } & $\begin{array}{l}\text { Equal variances } \\
\text { assumed }\end{array}$ & 4.651 & .032 & -2.111 & 458 & .035 & -.200 & .095 & -.386 & -.014 \\
\hline & $\begin{array}{l}\text { Equal variances } \\
\text { not assumed }\end{array}$ & & & -2.111 & 453.325 & .035 & -.200 & .095 & -.386 & -.014 \\
\hline \multirow[t]{2}{*}{ Non-explicit } & $\begin{array}{l}\text { Equal variances } \\
\text { assumed }\end{array}$ & 1.824 & .177 & 2.704 & 458 & .007 & .339 & .125 & .093 & .586 \\
\hline & $\begin{array}{l}\text { Equal variances } \\
\text { not assumed }\end{array}$ & & & 2.704 & 453.267 & .007 & .339 & .125 & .093 & .586 \\
\hline \multirow[t]{2}{*}{ Cautious } & $\begin{array}{l}\text { Equal variances } \\
\text { assumed }\end{array}$ & 3.520 & .061 & 2.284 & 458 & .023 & .270 & .118 & .038 & .502 \\
\hline & $\begin{array}{l}\text { Equal variances } \\
\text { not assumed }\end{array}$ & & & 2.284 & 450.430 & .023 & .270 & .118 & .038 & .502 \\
\hline \multirow[t]{2}{*}{ Ambitious } & $\begin{array}{l}\text { Equal variances } \\
\text { assumed }\end{array}$ & 3.139 & .077 & -2.081 & 458 & .038 & -.209 & .100 & -.406 & -.012 \\
\hline & $\begin{array}{l}\text { Equal variances } \\
\text { not assumed }\end{array}$ & & & -2.081 & 450.620 & .038 & -.209 & .100 & -.406 & -.012 \\
\hline
\end{tabular}

\subsection{Follow-Up Analysis \#1: Age-Based One-way ANOVA}

The independent samples t-test compared the mean ratings of LCBs between the Millennial and non-Millennial groups to identify any significant differences. In order to compare if there were significant differences in leadership preferences between five different age groups, I conducted a one-way analysis of variance (ANOVA). The purpose of this 
analysis was to compare the leadership preferences based on age, and try to test whether there were more dramatic differences across age groups. A one-way ANOVA is used to determine whether there are statistically significant differences between the means of more than two independent groups (McCrum-Gardner, 2008). Since I needed to compare the mean rating scores of 55 LCBs across five age groups of participants, a one-way ANOVA was an appropriate analytical test. As mentioned in the previous chapter, age data was collected as a categorical variable rather than a continuous variable. There were five different age groups (younger than $25 ; 26$ to $35 ; 35$ to $40 ; 41$ to 45 ; older than 45 ). The results of the ANOVA assessing differences between the five age groups in leadership preferences are shown in Table 5 (a full list of results is provided in Appendix B) (Table 5 shows the age-based oneway ANOVA). The results of the one-way ANOVA showed that of the $55 \mathrm{LCBs}$ rated, significant differences were found between the age groups' ratings in respect of only 4 LCBs: intra-group competitor $(\mathrm{F}(4,455)=4.247, \mathrm{p}=.002)$, collaborative $(\mathrm{F}(4,455)=2.522, \mathrm{p}$ $=.04)$, cautious $(\mathrm{F}(4,455)=2.669, \mathrm{p}=.032)$, and self-sacrificial $(\mathrm{F}(4,455)=2.721, \mathrm{p}$ $=.029)$. The means and standard deviations for these four LCBs rating scores for each age group are presented in Table 6.

In terms of intra-group competitor, its mean rating was lowest amongst the under-25 group (3.93), and highest amongst the over-45 group (4.86). In terms of collaborative, its mean rating was highest amongst the under-25 group (6.33), and lowest amongst both the 3640 (5.94) and over-45 (5.94) age groups. Furthermore, in terms of cautious, its mean rating was lowest amongst the 26-35 age group (3.22), and highest amongst the 41-45 group (3.75). Finally, the mean rating of self-sacrificial varied greatly between age groups. The mean score of the over-45 group was the highest (5.14).

Overall, the analysis of variance indicated that the effect of age on only 4 of 55 items was significant. However, no significant differences were found between the five age groups' ratings of the other $51 \mathrm{LCBs}$. Taken together, these results suggest that of the $55 \mathrm{LCBs}$ rated, younger participants were more likely to dislike a leader who is an intra-group competitor and cautious than older participants. Additionally, younger participants are more likely to prefer a leader who is collaborative, and are more inclined to believe this characteristic may contribute to a leader being outstanding than older participants. Furthermore, the preference for self-sacrificial varies greatly between age groups, with the older-than-45 group showing the greatest preference for it. However, there were far more similarities (51 out of 55) in leadership preferences between the different age groups than differences. 


\section{Table 5}

Age-Based One-way ANOVA (Differences significant at $p<.05$ only, see Appendix B for full results)

\begin{tabular}{|c|c|c|c|c|c|c|}
\hline & & $\begin{array}{l}\text { Sum of } \\
\text { Squares }\end{array}$ & df & Mean Square & $\mathrm{F}$ & Sig. \\
\hline \multirow[t]{2}{*}{ Intra-group competitor } & Between Groups & 36.880 & 4 & 9.220 & 4.247 & .002 \\
\hline & Within Groups & 987.694 & 455 & 2.171 & & \\
\hline \multirow[t]{2}{*}{ Collaborative } & Between Groups & 8.081 & 4 & 2.020 & 2.522 & .040 \\
\hline & Within Groups & 364.517 & 455 & .801 & & \\
\hline \multirow{2}{*}{ Cautious } & Within Groups & 725.277 & 455 & 1.594 & & \\
\hline & Total & 742.296 & 459 & & & \\
\hline \multirow[t]{3}{*}{ Self-sacrificial } & Between Groups & 22.616 & 4 & 5.654 & 2.721 & .029 \\
\hline & Within Groups & 945.558 & 455 & 2.078 & & \\
\hline & Total & 968.174 & 459 & & & \\
\hline
\end{tabular}

Table 6

Means and Standard Deviations for Four LCBs by Age Group

\begin{tabular}{|c|c|c|c|c|}
\hline & Age Group & $\mathrm{N}$ & $\mathrm{M}$ & SD \\
\hline \multirow{7}{*}{$\begin{array}{l}\text { Intra-group } \\
\text { competitor }\end{array}$} & & & & \\
\hline & $<25$ & 40 & 3.93 & 1.7 \\
\hline & $26-35$ & 142 & 4.63 & 1.396 \\
\hline & $36-40$ & 48 & 4.38 & 1.409 \\
\hline & $41-45$ & 103 & 4.29 & 1.519 \\
\hline & $>45$ & 127 & 4.86 & 1.468 \\
\hline & Total & 460 & 4.53 & 1.494 \\
\hline \multirow[t]{6}{*}{ Collaborative } & $<25$ & 40 & 6.33 & 0.888 \\
\hline & $26-35$ & 142 & 6.18 & 0.83 \\
\hline & $36-40$ & 48 & 5.94 & 0.836 \\
\hline & $41-45$ & 103 & 6.17 & 0.781 \\
\hline & $>45$ & 127 & 5.94 & 1.06 \\
\hline & Total & 460 & 6.1 & 0.901 \\
\hline \multirow[t]{6}{*}{ Cautious } & $<25$ & 40 & 3.53 & 1.467 \\
\hline & $26-35$ & 142 & 3.22 & 1.255 \\
\hline & $36-40$ & 48 & 3.48 & 1.487 \\
\hline & $41-45$ & 103 & 3.75 & 1.152 \\
\hline & $>45$ & 127 & 3.47 & 1.194 \\
\hline & Total & 460 & 3.46 & 1.272 \\
\hline \multirow[t]{6}{*}{ Self-sacrificial } & $<25$ & 40 & 4.63 & 1.48 \\
\hline & $26-35$ & 142 & 4.94 & 1.469 \\
\hline & $36-40$ & 48 & 4.46 & 1.584 \\
\hline & $41-45$ & 103 & 4.73 & 1.443 \\
\hline & $>45$ & 127 & 5.14 & 1.338 \\
\hline & Total & 460 & 4.87 & 1.452 \\
\hline
\end{tabular}




\subsection{Follow-up Analysis \#2: Independent Sample T-Test Between the Youngest and Oldest Age Groups}

Finally, in order to establish if there were differences in leadership preferences between the youngest respondents (i.e., those younger than 25) and the oldest respondents (i.e., those older than 45), I conducted an independent samples t-test comparing the mean LCB ratings of these two age groups. The purpose of this follow-up analysis was to compare the most extreme (in terms of age) members of each generational group (i.e., Millennials and non-Millennials). I did this with the view that if any substantive differences were to be found between the generations, they would most likely show up when comparing the extremes of each (i.e., the youngest Millennials, and the oldest non-Millennials). If few differences were found in this analysis, this would further support the results of my primary analysis (i.e., that there are few differences in leadership preferences between Chinese Millennials and nonMillennials).

The results of this follow-up analysis, shown in Table 7, indicate that of the 55 LCBs rated by respondents, significant differences between the youngest Millennials and oldest non-Millennials were found in respect of only 5 characteristics: intra-group competitor; clear; collaborative; self-sacrificial, and micro-manager. First, significant differences were found between the youngest $(\mathrm{M}=3.93, \mathrm{SD}=1.70)$ and oldest age groups $(\mathrm{M}=4.86, \mathrm{SD}=$ 1.468 ) in the mean rating scores for intra-group competitor, $\mathrm{t}(165)=-3.373, \mathrm{p}=.001$. The participants in the youngest age group rated it as less important to outstanding leadership than those in the oldest age group. Second, there was also a significant difference between the youngest age group $(\mathrm{M}=6.43, \mathrm{SD}=.747)$ and oldest age groups $(\mathrm{M}=5.94, \mathrm{SD}=1.041)$ in their mean ratings of clear, $\mathrm{t}(165)=2.703, \mathrm{p}=.008$. The participants in the youngest age group rated it as more central to outstanding leadership than those in the oldest age group. Third, a significant difference $(\mathrm{t}(165)=2.094, \mathrm{p}=.038)$ was found in respect of collaborative, with the youngest age group $(\mathrm{M}=6.33, \mathrm{SD}=.888)$ rating it as more central to outstanding leadership than the oldest age groups $(\mathrm{M}=5.94, \mathrm{SD}=1.06)$. In addition, a significant difference $(\mathrm{t}(165)=-2.076, \mathrm{p}=.039)$ was also found in respect of self-sacrificial, with the youngest age group $(\mathrm{M}=4.63, \mathrm{SD}=1.48)$ rating it as less important to outstanding leadership than the oldest age groups $(\mathrm{M}=5.14, \mathrm{SD}=1.338)$. Finally, a significant difference $(\mathrm{t}(165)=2.707, \mathrm{p}=.008)$ was also found in respect of micro-manager, with the youngest age group $(\mathrm{M}=4.78, \mathrm{SD}=1.423)$ rating it as more important to outstanding leadership than the oldest age groups $(\mathrm{M}=4.02, \mathrm{SD}=1.584)$. However, no significant differences were found between the youngest and oldest age groups in respect of the other 50 LCBs. 
Overall, compared with the oldest respondents in the sample (i.e., those over 45 years old), the youngest respondents (i.e., those younger than 25) were more likely to prefer a leader that was clear, collaborative, and a micro-manager. The youngest respondents were also more likely than the oldest respondents to dislike a leader who was an intra-group competitor. Additionally, the oldest respondents were more likely to believe that being selfsacrificial was an important aspect of leader effectiveness than the youngest participants. However, there appear to be many more similarities (50 out of 55) in leadership preferences between the youngest and the oldest age groups in this study than differences.

\section{Table 7}

Independent Samples t-Test between the youngest and oldest age groups (Differences significant at $p<.05$ only, see Appendix $C$ for full results)

\begin{tabular}{|c|c|c|c|c|c|c|c|c|c|c|}
\hline & & \multirow[b]{2}{*}{$\mathrm{F}$} & \multirow[b]{2}{*}{ Sig. } & \multirow[b]{2}{*}{$\mathrm{t}$} & \multirow[b]{2}{*}{$\mathrm{df}$} & \multirow{2}{*}{$\begin{array}{l}\text { Sig. (2- } \\
\text { tailed) }\end{array}$} & \multirow{2}{*}{$\begin{array}{l}\text { Mean } \\
\text { Differe } \\
\text { nce }\end{array}$} & \multirow{2}{*}{$\begin{array}{l}\text { Std. Error } \\
\text { Difference }\end{array}$} & \multicolumn{2}{|c|}{$\begin{array}{c}95 \% \text { Confidence } \\
\text { Interval of the } \\
\text { Difference }\end{array}$} \\
\hline & & & & & & & & & Lower & Upper \\
\hline \multirow[t]{2}{*}{$\begin{array}{l}\text { Intra-group } \\
\text { competitor }\end{array}$} & $\begin{array}{l}\text { Equal variances } \\
\text { assumed }\end{array}$ & $\begin{array}{r}2.90 \\
4\end{array}$ & 0.090 & $\begin{array}{r}- \\
3.373\end{array}$ & 165 & 0.001 & -0.933 & 0.277 & -1.480 & -0.387 \\
\hline & $\begin{array}{l}\text { Equal variances } \\
\text { not assumed }\end{array}$ & & & 3.124 & 58.454 & 0.003 & -0.933 & 0.299 & -1.531 & -0.335 \\
\hline \multirow[t]{2}{*}{ Clear } & $\begin{array}{l}\text { Equal variances } \\
\text { assumed }\end{array}$ & $\begin{array}{r}2.18 \\
4\end{array}$ & 0.141 & 2.703 & 165 & 0.008 & 0.480 & 0.178 & 0.129 & 0.831 \\
\hline & $\begin{array}{l}\text { Equal variances } \\
\text { not assumed }\end{array}$ & & & 3.201 & 90.785 & 0.002 & 0.480 & 0.150 & 0.182 & 0.778 \\
\hline \multirow[t]{2}{*}{ Collaborative } & $\begin{array}{l}\text { Equal variances } \\
\text { assumed }\end{array}$ & $\begin{array}{r}0.83 \\
0\end{array}$ & 0.364 & 2.094 & 165 & 0.038 & 0.388 & 0.185 & 0.022 & 0.754 \\
\hline & $\begin{array}{l}\text { Equal variances } \\
\text { not assumed }\end{array}$ & & & 2.295 & 77.008 & 0.024 & 0.388 & 0.169 & 0.051 & 0.725 \\
\hline \multirow[t]{2}{*}{$\begin{array}{l}\text { Self- } \\
\text { sacrificial }\end{array}$} & $\begin{array}{l}\text { Equal variances } \\
\text { assumed }\end{array}$ & $\begin{array}{r}0.69 \\
1\end{array}$ & 0.407 & $2.07 \overline{6}$ & 165 & 0.039 & -0.517 & 0.249 & -1.008 & -0.025 \\
\hline & $\begin{array}{l}\text { Equal variances } \\
\text { not assumed }\end{array}$ & & & 1.970 & 60.425 & 0.053 & -0.517 & 0.262 & -1.041 & 0.008 \\
\hline \multirow[t]{2}{*}{$\begin{array}{l}\text { Micro- } \\
\text { manager }\end{array}$} & $\begin{array}{l}\text { Equal variances } \\
\text { assumed }\end{array}$ & $\begin{array}{r}0.77 \\
7\end{array}$ & 0.379 & 2.707 & 165 & 0.008 & 0.759 & 0.281 & 0.205 & 1.313 \\
\hline & $\begin{array}{l}\text { Equal variances } \\
\text { not assumed }\end{array}$ & & & 2.862 & 71.967 & 0.006 & 0.759 & 0.265 & 0.230 & 1.288 \\
\hline
\end{tabular}

\subsection{Summary}

This chapter presented the analysis and results of the research. This research was exploratory in nature, meaning I did not have specific hypotheses to be tested. Instead, I explored, in an open-ended way, the nature of the leadership preferences of Chinese Millennials and non-Millennials, and sought to identify any differences or similarities. Specifically, quantitative analysis was applied in three steps to determine whether there were significant differences in leadership preferences between Chinese Millennials and nonMillennials. Significant differences were found in certain LCBs in three steps analyses. In the 
above three analyses, significant differences in leadership preferences between Chinese Millennials and non-Millennials were found in respect of only 13 of 55 LCBs: bossy, inspirational, intra-group conflict avoider, orderly, modest, non-explicit, cautious, ambitious, intra-group competitor, clear, collaborative, self-sacrificial, and micro-manager. However, the results suggest that there are some slight differences between the generational groups in their leadership preferences, but overall, the two groups have similar preferences. The primary analysis shows that of the $55 \mathrm{LCBs}$ assessed, there were relatively few differences between Chinese Millennials and non-Millennials in the extent to which they perceived these LCBs as central to leader effectiveness. On the contrary, there were many similarities in apparent leadership preferences between these two generation groups. Two follow-up analyses - an age-based one-way ANOVA, and an independent samples t-test between the youngest and oldest age groups - further confirms the results of the first primary analysis. Even when comparing the preferences of the oldest non-Millennials with the youngest Millennials, few substantive differences in leadership preferences were found. Overall, then, Chinese Millennials and non-Millennials seem to have similar leadership preferences, especially in the extremes (i.e., in terms of what LCBs they associate with very good and very poor leadership). It should also be noted that the differences between the groups were all related to LCBs that in the middle of the scale (i.e., that neither group saw as particularly helpful or unhelpful for leadership). 


\section{CHAPTER FIVE: DISCUSSION AND CONCLUSION}

This study explored the leadership preferences of Chinese Millennials versus nonMillennials. This study addressed the question: In what ways, if at all, do the leadership preferences of Chinese Millennials differ from those of Chinese non-Millennials? The results of this study indicate few significant differences, and contrarily, many similarities between Chinese Millennials and non-Millennials in their leadership preferences. In general, then, the results suggest that Chinese Millennials hold similar leadership preferences to older generations of Chinese. In this chapter, I summarize the results of the study, and discuss how they contribute to relevant research areas. I also explore some potential theoretical explanations for the results, and provide recommendations for future research. I conclude by discussing the limitations of this study, and its practical implications.

\subsection{Contributions to Research}

Many studies (e.g., Wieck et al, 2002; Arsenault, 2004; Sessa et al., 2007) conducted in Western contexts have found evidence of not only differences but also similarities between generations (Parry \& Urwin, 2011). Broadly speaking, Western-based research has provided mixed results regarding the potential for generational differences in leadership preferences (Parry \& Urwin, 2011; Rudolph, Rauvola \& Zacher, 2018), and has also provided evidence that generations may in fact have many similarities in preferred leadership characteristics. For example, Wieck et al. (2002) found a high degree of agreement between the generational groups in their study regarding their desired and undesired leadership traits (i.e., both younger and older generations valued honesty, supportiveness, and good communication). Arsenault (2004) found both differences across generations, as well as many similarities (i.e., the attributes of honesty, loyalty and competence of different generations were ranked as more-or-less equivalent in importance across the generations). But few studies on this issue have been conducted in Eastern contexts generally, and the Chinese context specifically (see Yi et al., 2010, for a notable exception). Yi et al. (2010) compared the leadership preferences of Cultural Revolution Generation (i.e., born in the 1960s), Social Reform Generation (i.e., born in the 1970s), and Millennials (i.e., born in the 1980s and 1990s) in China. Although the generational differences in leadership preferences was not the focus of their research, they did find significant differences in preferences for only 4 leadership traits among 15 leadership traits across the three generations. The present study attempted to address this lack of comparative research on the leadership preferences of Millennials and non-Millennials in the 
Chinese context, and in doing so, enables us to better understand the leadership preferences of these groups, as well as their similarities and differences.

The results of this study converge with those of other related studies conducted both in Western and Eastern societies, which found that people from different generations show more similarities than differences in preferred leadership characteristics. (e.g., Bako, 2018; Wieck et al., 2002; Sessa et al., 2007; Yi et al., 2010). As in my research, Bako (2018) applied the leadership questionnaire of the GLOBE project to explore generational differences in leadership preferences in Turkey, finding significant differences in respect of only 3 (i.e., self-sacrifice, conflict-inducer, and face saver) of the 16 leadership characteristics between four generations (i.e., Baby Boomers, Generation X, Millennials, and Younger). Although there are few Chinese studies of potential generational differences in leadership preferences, research conducted in the Chinese context (Yi et al., 2010) found no substantive differences in leadership preferences between different generations (i.e., Cultural Revolution Generation, Social Reform Generation, Millennials). The results of my study are consistent with Yi et al.'s (2010) findings that Chinese Millennials are more similar than they are different to non-Millennials as far as leadership preferences are concerned. In this way, my study also supports the broader notion that the younger generation in China retains commonalities with older generations ( $\mathrm{Lu} \& \mathrm{Kao}, 2002$ ).

Additionally, from a direct comparison of the mean rating scores for $55 \mathrm{LCBs}$ in my study, some of LCBs were in similar relative ranking positions across the generations. Both Millennials and non-Millennials scored the LCBs of self-interested, tender, egocentric and secretive the lowest, but also showed a strong preference for the LCBs of trustworthy, administratively skilled, team builder, inspirational and honest. These findings are consistent with the research of Wieck et al. (2002), Sessa et al. (2007) and Yi et al. (2010), who found that all generational cohorts strongly valued honesty. Additionally, consistent with my research finding that both Millennials and non-Millennials attach great importance to teambuilding leadership, Yi et al.'s (2010) research showed that all generations a) prefer leaders who value the team, and b) believe that this trait is very important for leadership.

Taken together, Chinese Millennials in this study show more similarities with nonMillennials in their leadership preferences than differences, which diverges from the historical and widespread assumption of generational heterogeneity. Although it is widely believed that, due to factors such as the One-Child Policy and major social changes (e.g., China's economic growth, the development of the Internet), Chinese Millennials have become a unique social group with unique characteristics and personalities (Li, 2015; Zhao, 
2018), my findings support the view that Chinese Millennials are not completely different from older generations of Chinese. At least from this research, they are not that different from the older generation in terms of their leadership preferences in the workplace. They may remain commonality with the previous generations to some extent in terms of values and ideas. Furthermore, this study also fills a gap in research on generational differences in the Chinese context, specifically in terms of generational differences in leadership preferences. As Parry and Urwin (2011) stated, generational differences appear to have no appreciable impact on work process and results, as well as work-related attitudes. Likewise, Costanza et al. (2012) stated there are no (or only very slight) generational differences in work-related attitudes. The results of this study not only provide empirical evidence to support the views of Parry and Urwin (2011) and Costanza et al. (2012), but also extend the research of generational differences in leadership preferences to the Chinese context. The generational differences in leadership preferences are not very obvious in the Chinese context as well. However, the findings of this study also highlight the need for further theoretical and empirical investigations of why exactly this is the case.

\subsection{Potential Explanations for Findings}

While this study provides empirical evidence suggesting that Chinese Millennials and non-Millennials have similar leadership preferences, understanding why exactly this may be the case is a more complicated issue. Below, I draw on relevant literature to theorize about the social and psychological mechanisms that might underpin my findings. In doing so, I aim to add depth to the research findings as well as provide ideas and directions for further research.

\subsubsection{Traditional Chinese culture is consolidated and inherited}

As stated in my literature review, recent research has seen leadership theory develop in a way that embraces the impact of culture. Culturally endorsed leadership theory (CLT) suggests that members of a culture will tend to hold similar understanding of the qualities and characteristics that make for an outstanding leader (Javidan et al., 2006). The results of the GLOBE research project (House et al., 2004) reinforced this culture-specific perspective and the importance of culture in leadership preferences. Moan and Hetland (2012) have also asserted that much evidence supports the notion that leadership preferences are culturally contingent. The findings of the review by Moan and Hetland (2012) support the view that culture plays an important role in people's leadership preferences. People within a common 
cultural group have also been found to share relatively stable, common beliefs about leadership (Javidan et al., 2006). In addition, Oc (2018) and Junker and van Dick (2014) suggested that macro cultural characteristics could shape people's implicit leadership prototypes, leading to similar prototypes being endorsed amongst members of a single cultural group. Indeed research has found, regardless of generational cohort, that there are no significant differences in leadership preferences within Confucian cultural clusters (House et al., 2004; Li et al., 2010).

In light of the research described above, the first potential explanation for the similarities in leadership preferences between Chinese Millennials and non-Millennials I observed in this study is that traditional Chinese culture is consolidated and inherited. The research of Lu and Kao may support this proposition. Lu and Kao (2002) studied the characteristics of younger and older generations in Taiwan, and found a coexistence of generational similarities and differences due to the stability of Chinese traditional culture: as the culture remains constant, and changes fairly slowly, the younger generations under the influence of that culture are socialised according to and retain traditional values like the older generations ( $\mathrm{Lu} \& \mathrm{Kao}, 2002)$.

Although Confucianism originated thousands of years ago in ancient China, Confucianism has penetrated Chinese culture and remains an important aspect of the culture today (Koehn, 2001). Koehn (2001) examined the Confucian concept of trustworthiness and the business practice of trustworthiness in China, finding that Confucian values still impact Chinese people's evaluation of a leader in modern times. The emphasis on trustworthiness in Confucianism means that Chinese people not only tend to value the material success of leadership, but also pay attention to the virtues of leader (Koehn, 2001). According to Koehn (2001), when judging whether a leader is effective, Chinese people also consider whether they are an ethical leader, and whether they have virtues such as selflessness, integrity, and reliability. As Romar (2002) stated, the manifestation of Confucianism in evaluating behaviours and characteristics is that people affected by Confucianism care about its morality and its impact on both individuals and others. My research findings also reflect Romar's (2002) view: I found that both Chinese Millennials and non-Millennials attach great importance to trustworthiness and honesty, but dislike self-interested and egocentric leadership behaviours, reflecting that under the influence of Confucianism, the younger generation in China, like the older generations, prefers leaders with traditional virtues (e.g., reliability, honesty, selflessness). 
In addition, Confucianism has been continuously consolidated and inherited in Chinese thinking through family education (Cai, 2017), and has been expressed through words and deeds, while affecting the next generation of Chinese people. Confucian values have played a pivotal role in the family environment and are deeply rooted in family life as well as family education in China (Cai, 2017). Moreover, traditional culture education is also an important aspect of university education in China, which directly affects the value orientation of contemporary Chinese university students (Hong, 2017). Based on these observations, I propose that these traditional ideas are consolidated by education and affect the cogitation of both older and younger generations of Chinese, potentially leading to Chinese Millennials and non-Millennials having similar leadership preferences.

\subsubsection{People have similar fundamental needs, regardless of generational membership}

Moan and Hetland (2012) reviewed much extant research that supports both the universal and culture-specific perspective on leadership preferences, and hence suggested that leadership preferences are partly universal, and also partly culturally contingent. A universal perspective on leadership preferences suggests that there are certain basic attributes of effective leadership that all (or at least most) people agree on, which set leadership preferences at a human level. In terms of what factors shape this universal leadership preference, many scholars have suggested that fundamental human needs, such as psychological security and safety (Gillath \& Hart, 2010), and the needs for connection and inclusion (Boatwrigh \& Forrest, 2000) bear on followers' leadership preferences, at least to some extent. Moreover, Schoel et al. (2011) found that uncertainty triggers a preference for different types of leadership based on the individual's level of self-esteem, which highlights the influence of self-esteem — a basic component of human psychology — and the need for certainty on leadership preferences.

Thus, despite the common assumption of generational differences, a universalist perspective on leadership preferences suggests that, because Millennials and non-Millennials are all human beings, they have similar human needs that bear on their leadership preferences. Considering the universality of human needs and their impact on leadership preferences might help to explain the findings of the current study. It is possible that the similarities in leadership preferences between Chinese Millennials and non-Millennials result from their similar needs as humans. For example, both Millennials and non-Millennials in this study valued the characteristics of trustworthy and honest but were strongly opposed to 
the characteristic of self-interested, perhaps because all human beings have a need to feel respected and recognized by their leaders and co-workers (Heaphy \& Dutton, 2008). Similarly, both Millennials and non-Millennials in my study valued team-building leaders, but disliked egocentric and secretive leaders. Invoking Maslow's hierarchy of needs (Maslow, 1954) (i.e., five categories of needs: physiological needs, safety needs, social belonging, self-esteem and self-actualization), I propose that this result may be because of a shared need for social belonging and sense of connection with one's team.

\subsubsection{The impact of intergenerational interactions and a shared organizational environment}

While sociocultural factors and psychological needs surely play an important role in shaping people's implicit leadership prototypes, and thus, their leadership preferences, organizational environments and interactions between members within these environments are also important considerations (Oc, 2018; Junker \& van Dick, 2014). In today's Chinese organizations, the labour force is comprised of people from several generations. As a result, Millennials and non-Millennials work alongside, interact with, lead, and are led by one another. Lester et al. (2012) found that perceived generational differences in work-related beliefs significantly outnumber actual generational differences. In other words, Lester et al. (2012) found limited evidence of extensive generational differences in work-related beliefs, but ironically, much evidence of a widespread perception that these differences exist. Lester et al. (2012) proposed a potential explanation that the interactions between workers and colleagues from different generations may affect the perceptions they hold. In the process of interaction, people of different generations will realize that the perceived generational differences are not real, and the actual differences will be understood by each other or even reduced subsequently during the interaction (Lester et al., 2012).

Lester et al.'s (2012) explanation may also help to explain the results of the current study. Although the specific organizational environment differs between different organizations, at this stage, when considering the organizational environment of Chinese business and the interaction between members of the organizations, the participation and influence of non-Millennials cannot be ignored. Chinese Millennials' interaction with nonMillennial co-workers, as well as non-Millennial mentors and leaders, may shape their leadership preferences, such that they become similar to those of non-Millennials - and vice-versa.

Furthermore, Yi et al. (2010) point out that most Millennials are still at earlier career stages (i.e., in the development and growth stages). Perhaps as they progress through their 
careers, they will develop significantly different leadership preferences from the older generations when they were at equivalent career stages. In the future, as non-Millennials retire and move out of workplaces and organizations, Millennials may develop and change their leadership preferences in an organizational environment where they are all peers, and are interacting with a younger generation (i.e., Generation Z).

In addition, in much early literature, Mannheim (1970) noted the fact that the transition from one generation to another occurs continuously, and this fact tends to make the interaction smoother. In this interaction process, it is not always the oldest person who will meet the youngest person immediately; the initial connection is made by other, intermediary generations (Mannheim, 1970). All intermediaries play their role: while they cannot wipe out generational differences, they can at least mitigate them (Mannheim, 1970). This perspective can also be used to explain why generational differences in leadership preferences were not so obvious in this study. It is possible that members of the intermediary-generation that Millennials meet when growing up or at work brought the values and attitudes of older generations, enabling Millennials to understand and possibly absorb those ideas and values as part of their own values. This in-turn may lead to similar leadership preferences between Millennials and non-Millennials. This view is supported by Yi et al.'s (2010) finding that the Social Reform Generation, as the intermediate generation, did not show significant differences in leadership preferences compared with both the older Cultural Revolution Generation, and younger Millennials.

\subsection{Future Research Directions}

The current investigation addressed the question, "In what ways, if at all, do the leadership preferences of Chinese Millennials differ from those of Chinese non-Millennials?" and provided empirical evidence suggesting that there are many more similarities in leadership preference than differences between Chinese Millennials and non-Millennials. I have also proposed some potential explanations for these results. However, existing research is still insufficient to explain what factors can explain generational differences/similarities in leadership preferences. As recommended by Yang, Yu and Wu (2018), researchers need to further develop their understanding of the root causes of observed generational differences or similarities, which may be the first step to bridging any generational gap in the workplace. Therefore, the priority of future research in the area should be to explore why Chinese Millennials and non-Millennials have similar leadership preferences, as the results of the 
current study suggest. In other words, I recommend a theoretical investigation of what factors may contribute to intergenerational homogeneity, particularly (though not only) in terms of the leadership preferences. In this research, I focused on the Chinese context. However, further research regarding the factors that may reduce (or exacerbate) generational differences could expand to other cultural clusters and countries to examine whether cultural influence plays an important role.

Taking into account the developmental change of work-related values and leadership preferences specifically, and assuming sufficient resources, I recommend a time-lagged study. Twenge (2010) discussed that the best design for determining generational differences is the time-lag study, which examines people of the same age at different points in time. The obvious advantage of time-lag design is that it can isolate generational differences from differences caused by age and time-period effects (Rhodes, 1983). Yi et al. (2010) suggested that a large sample comparison across a long time span may be more effective in distinguishing generational differences as developmental differences may be excluded. Similarly, Lyons and Kuron (2014) pointed out that as each generation experiences its own life course, any differences observed between generations at one point in time may change over time, and recommended time-lagged research to provide a fuller picture of generational differences in leadership preferences. Therefore, the scope of this study could be extended in future research in this way, namely, taking full account of the developmental changes over time in people's leadership preferences, and increasing the number of research samples while extending the time span of the research. Through a time-lagged research design, researchers may be able to more convincingly determine whether there really are universal generational differences in leadership preferences, both within and beyond the Chinese context.

In addition, I recommend a multi-industry study of generational differences in leadership preferences. In a cross-industry study, Yu and Miller (2005) found generational differences in leadership preferences in the manufacturing industry, but not the education industry. Since I intended for my research to have generality and span as many industries as possible, I did not consider the potential impact of the industry environment on leadership preferences in this study, but this represents a worthwhile direction for future research. Therefore, I suggest that future research could undertake comparative studies of generational differences in leadership preferences across multiple industries, so as to investigate how, if at all, certain industry environments bear on generational similarities/differences in leadership preferences. 


\subsection{Limitations}

Certain methodological limitations of the current study need to be borne in mind when interpreting its findings and implications. First, features of the sample make it difficult to generalize the findings to all populations in China. The sample size of this study (230 Millennials and 230 non-Millennial participants) is too small relative to the large Chinese population to be deemed representative of it. In addition, taking into account the significant diversity (e.g., geographic district, ethnicity, the level of economic development, sub-culture, religion, etc.) within China, the leadership preferences of all members of the Chinese population would not therefore have been captured in this study. Due to the inherent time and resource constraints of a Masters project, it was difficult for this study to expand the sample size and cover greater diversity of the Chinese population. However, future studies, with sufficient time and resources, could take this diversity (e.g., in terms of ethnicity, socioeconomic status, sub-culture, religion, etc.) into account and use more diverse samples.

Moreover, this research collected data through the sample service provided by the online survey tool Wenjuanxing. All participants in this study were from Wenjuaxing's large database of survey participants (over 2.6 million members). However, there is a potential selection bias here, because only those who are able to use computers and the Internet, and have voluntarily joined Wenjuanxing could be selected to join the sample database. Although Wenjuanxing has a substantial sample database, there is still a large part of the Chinese population that cannot be accessed through this survey tool. While a sample service like Wenjuanxing is a very effective method, future research needs to adopt a sampling strategy (for example, direct cold calling and/or snowball sampling) that overcomes this limitation.

Furthermore, there was no restriction on the industry that sample participants in this study worked in, and data about this issue was not collected. As such, the participants were from a variety industries, meaning there may be variation at the industry level in the leadership preferences of different generations, which was not detected by this study. Research on generational differences in leadership preferences has usually been conducted for a certain industry or a specific group of people, such as nurses (Wieck, 2002). In a crossindustry study, Yu and Miller (2005) found generational differences in leadership preferences in the manufacturing industry, but not the education industry. Therefore, another limitation of this study is that it does not take into account the potential impact of industry environment on leadership preference, but this is a worthwhile direction for future research. On a positive note, compared to some studies where samples came from a single organization or industry, 
having no restrictions on the industry in which participants worked in potentially makes the research findings more representative of the broader population.

In addition, since people's implicit leadership theories (ILTs) are an accurate predictor of leadership preferences, ILTs were treated as more-or-less equivalent to people's leadership preferences in this study. Participants' leadership preferences were captured by recording their expressed understanding of what constitute outstanding leader characteristics. However, these two concepts are nevertheless distinct. Although many previous studies (e.g., House et al., 2004; Li \& Duncan, 2010; Lisbon, 2010; Lin \& Sun, 2018) have also used ILT to represent leadership preferences, it might be better to more directly measure people's leadership preferences (e.g., by asking what leadership traits people prefer, rather than what traits they believe make for an outstanding leader).

Finally, due to time and resource constraints, I personally translated the GLOBE questionnaire I used from English to Chinese. It is possible that, through this process, the meaning of the LCBs in the Chinese version of the questionnaire changed compared to the original English meaning, which may affect participants' understanding of concepts and judgement of questions. For example, the definition of diplomatic from the English GLOBE questionnaire is "skilled at interpersonal relations", which seems to be a positive word. However, the Chinese translation of diplomatic I used (精于人际交往的) also has negative connotations to some extent: in Chinese, a person who is very good at dealing with interpersonal relationships may also be regarded as being deceitful and conniving, which may lead to Chinese participants interpreting the meaning of this characteristic differently. In order to overcome this limitation and reduce the bias, I suggest future research use professional translation agencies for questionnaire translation, as well as back-translation to check the accuracy of translation.

\subsection{Practical Implications}

The present study has important implications for leaders who work in Chinese contexts. By increasing understanding of the research evidence that exists about leadership preferences across generations, leadership challenges in the multi-generation workforce can be overcome (Lisbon, 2010). A better understanding of Millennials' leadership preferences, as well as differences and similarities in these preferences among different generations, also enables organizations and leaders to better implement leader effectiveness with the growing number of Millennial employees. Given this study's central finding that there are more 
similarities in leadership preference than differences between Chinese Millennials and nonMillennials, managers in Chinese contexts should be somewhat cautious about dedicating copious effort to accounting for generational differences in their management and leadership activities. In fact, by highlighting the many commonalities in leadership preferences that potentially exist across generations in China, this study allows organizations and leaders to better understand and adjust their leadership to more appropriately manage the mixed workforce of Millennials and non-Millennials. For example, leaders who pay more attention to team building and inspiration may be more preferred by all employees, as both Millennials and non-Millennials value the characteristics of team builder and inspirational. Trustworthiness is also highly valued by Millennials and non-Millennials, and perhaps even younger generations due to the cultural influence.

It is also important for organizations and leaders to recognise the distinction between the widespread assumption of generational differences on the one hand, and the actual differences (or lack thereof) that exist on the other. This might be especially true in the Chinese context, because the results of this study revealed that the similarities in leadership preferences between Millennials and non-Millennials remained stronger than the differences. A common view is that due to specific social, cultural, and economic changes, Chinese Millennials hold different values and lifestyles from older generations (Chen, 2007), perhaps leading them to hold significantly different leadership preferences as well. These assumptions may cause leaders to unnecessarily worry about how to satisfy Millennial and non-Millennial employees with supposedly vastly different leadership preferences. The findings of this study suggest managers efforts might be better focused on simply trying to become more effective leaders in the eyes of members of both younger and older generations, as they seemingly have similar leadership preferences.

In addition, managers will be most effective if they can understand the factors that may influence employees' leadership preferences. The differences in leadership preferences and perceptions may cause conflicts and clashes between non-Millennial leaders and Millennial employees (Zhao \& Xu, 2019). Recognizing potential causes of and mechanisms underlying the similarity in leadership preferences between Millennials and non-Millennials may enable managers to better deal with these conflicts. For example, more interactions and communications between Millennials and non-Millennials may be a good way to promote mutual understanding and find a balance. Furthermore, Yi et al. (2010) suggested that employees are first and foremost individuals, and then members of a certain generational cohort, so they should be managed as individuals. Although Chinese Millennials and non- 
Millennials have similar leadership preferences in general, it does not mean that the differences can be ignored. These differences may be due to intergenerational differences or individual differences. However, accepting differences and actively seeking commonalities are the keys to leading a mix of old and young generations of employees for organizations and managers.

\subsection{Conclusion}

While reviewing the literature, I found that there was a gap in understanding the generational differences in leadership preferences in the context of China. This study sought to fill this gap by exploring and comparing the leadership preferences of Chinese Millennials and non-Millennials. The results indicate that Chinese Millennials show many more similarities with non-Millennials in their leadership preferences than differences. Both generational groups prefer leaders who are trustworthy, administratively skilled, team builder, inspirational and honest, but dislike self-interested, tender, egocentric and secretive leaders. This study allows Chinese managers and organizations to understand the leadership preferences of employees from different generations as well as how to most effectively lead the current multi-generational workforce in China. 


\section{REFERENCES}

Ahn, M. J., \& Ettner, L. W. (2014). Are leadership values different across generations?. Journal of Management Development, 33(10), 977-990.

Ali, M., Ghoneim, A., Irani, Z., \& Dwyer, R. J. (2009). Prepare for the impact of the multigenerational workforce!. Transforming Government: People, process and policy, 3(2), 101-110.

Anderson, H. J., Baur, J. E., Griffith, J. A., \& Buckley, M. R. (2017). What works for you may not work for (Gen) Me: Limitations of present leadership theories for the new generation. The Leadership Quarterly, 28(1), 245-260.

Arsenault, P. M. (2004). Validating generational differences: A legitimate diversity and leadership issue. (Author Abstract). Leadership \& Organization Development Journal, 25(2), 124-141.

Avolio, B. J., Bass, B. M., \& Jung, D. I. (1999). Re-examining the components of transformational and transactional leadership using the Multifactor Leadership. Journal of Occupational and Organizational Psychology, 72(4), 441-462.

Bako, M. (2018). Different leadership style choices, different generations. Prizren Social Science Journal, 2(2), 127-143.

Boatwright, K. J., \& Forrest, L. (2000). Leadership preferences: The influence of gender and needs for connection on workers' ideal preferences for leadership behaviors. Journal of Leadership Studies, 7(2), 18-34.

Brain, K., \& Lewis, D. (2004). Exploring leadership preferences in multicultural workgroups: An Australian case study. Leadership \& Organization Development Journal, 25(3), 263-278.

Burns, T. R., \& Engdahl, E. (1998). The social construction of consciousness. Part 1:

collective consciousness and its socio-cultural foundations. Journal of Consciousness Studies, 5(1), 67-85.

Cai, L. (2017). Value Research of the Traditional Confucian Moral Education Thoughts in Contemporary Family Education [in Chinese]. Nanning Normal University.

Charmaz, K. (2014). Constructing Grounded Theory. Sage.

Chen, H. M. (2007). People born in the 1960s and contemporary cultural spirit [in Chinese]. China Youth Study, 5, 25-30.

Chen, J., \& Lian, R. (2015). Generational differences in work values in China. Social Behavior and Personality: An International Journal, 43(4), 567-578. 
Chen, P. J., \& Choi, Y. (2008). Generational differences in work values: a study of hospitality management. International Journal of Contemporary Hospitality Management, 20(6), 595-615.

Chou, S. Y. (2012). Millennials in the workplace: A conceptual analysis of millennials' leadership and followership styles. International Journal of Human Resource Studies, 2(2), 71-83.

Clarke, K. S. (2014). An analysis of the relationship of leadership styles, satisfaction with the leader, and leadership effectiveness among generations: A quantitative study (Doctoral dissertation, Capella University). Available from ProQuest Dissertations \& Theses Global database. (UMI No. 3617129)

Cohen, J. (1992). A power primer. Psychological Bulletin, 112(1), 155-159.

Cohen, J. (1992). Statistical power analysis. Current Directions in Psychological Science, 1(3), 98-101.

Cole, N. L. (2020). The concept of collective consciousness. Retrieved from https://www.thoughtco.com/collective-consciousness-definition-3026118

Costanza, D. P., \& Finkelstein, L. M. (2015). Generationally based differences in the workplace: Is there a there there?. Industrial and Organizational Psychology, 8(3), 308.

Costanza, D. P., Badger, J. M., Fraser, R. L., Severt, J. B., \& Gade, P. A. (2012). Generational differences in work-related attitudes: A meta-analysis. Journal of Business and Psychology, 27(4), 375-394.

Dulin, L. (2008). Leadership preferences of a generation Y cohort: A mixed-methods investigation. Journal of Leadership Studies, 2(1), 43-59.

Ehrhart, M. (2012). Self-concept, implicit leadership theories, and follower preferences for leadership. Zeitschrift Fur Psychologie, 220(4), 231-240.

Epitropaki, O., \& Martin, R. (2005). From ideal to real: a longitudinal study of the role of implicit leadership theories on leader-member exchanges and employee outcomes. Journal of Applied Psychology, 90(4), 659-676.

Farag, A. A., Tullai-Mcguinness, S., \& Anthony, M. K. (2009). Nurses' perception of their manager's leadership style and unit climate: are there generational differences?. Journal of Nursing Management, 17(1), 26-34.

Farh, J. L., \& Cheng, B. S. (2000). A cultural analysis of paternalistic leadership in Chinese organizations. In Li, J., Tsui, A. \& Weldon, E. (Eds.), Management and organizations in the Chinese context (pp. 84-127). London: Palgrave Macmillan. 
Forsyth, D. R. (2018). Group Dynamics. Cengage Learning.

Fukushige, A., \& Spicer, D. P. (2007). Leadership preferences in Japan: An exploratory study. Leadership and Organization Development Journal, 28(6), 508-530.

Gillath, O., \& Hart, J. (2010). The effects of psychological security and insecurity on political attitudes and leadership preferences. European Journal of Social Psychology, 40(1), $122-134$.

Heaphy, E. D., \& Dutton, J. E. (2008). Positive social interactions and the human body at work. Academy of Management Review, 33(1), 137-162.

Hill, R. P. (2002). Managing across generations in the 21st century: Important lessons from the ivory trenches. Journal of Management Inquiry, 11(1), 60-66.

Hong, Z. (2017). Significance of Chinese traditional culture education in college ideological and political work. Journal of Huaihai Institute of Technology (Humanities \& Social Sciences Edition), 24(1), 41-46.

House, R. J., Hanges, P. J., Javidan, M., Dorfman, P. W., \& Gupta, V. (Eds.). (2004).

Culture, Leadership, and Organizations: The GLOBE Study of 62 Societies. Sage.

Huff, C. (2006). Consider employee age when choosing awards. Workforce Management, 85(17), 28-28.

Javidan, M., Dorfman, P. W., De Luque, M. S., \& House, R. J. (2006). In the eye of the beholder: Cross cultural lessons in leadership from project GLOBE. Academy of Management Perspectives, 20(1), 67-90.

Jiang, X., \& Hui, Y. (2016). Impacts of optimism and job characteristics on job burnout among the Millennial generation: Evidence from a survey of community service workers in Shaanxi, China. Revista de Cercetare si Interventie Sociala, 53, 185-212.

Joshi, A., Dencker, J. C., \& Franz, G. (2011). Generations in organizations. Research in Organizational Behavior, 31, 177-205.

Junker, N. M., \& Van Dick, R. (2014). Implicit theories in organizational settings: A systematic review and research agenda of implicit leadership and followership theories. The Leadership Quarterly, 25(6), 1154-1173.

Koehn, D. (2001). Confucian trustworthiness and the practice of business in China. Business Ethics Quarterly, 11(3), 415-429.

Kowske, B. J., Rasch, R., \& Wiley, J. (2010). Millennials'(lack of) attitude problem: An empirical examination of generational effects on work attitudes. Journal of Business and Psychology, 25(2), 265-279. 
Kupperschmidt, R. (2000). Multigeneration employees: Strategies for effective management. The Health Care Manager, 19(1), 65-76.

Lester, S. W., Standifer, R. L., Schultz, N. J., \& Windsor, J. M. (2012). Actual versus perceived generational differences at work: An empirical examination. Journal of Leadership \& Organizational Studies, 19(3), 341-354.

Li, Y. (2015). China's Generation Y. Global Times. Available from http://www.globaltimes.cn/content/924706.shtml

Li, Y., \& Duncan, P. (2010). A comparison of the cultural impacts on leadership preferences between overseas Chinese petroleum professionals and GLOBE scores. (Doctoral dissertation). Available from ProQuest Dissertations \& Theses Global database. (UMI No. 3410316)

Limsila, K., \& Ogunlana, S. O. (2008). Performance and leadership outcome correlates of leadership styles and subordinate commitment. Engineering, construction and architectural management, 15(2), 164-184.

Lin, C. H., \& Sun, J. M. (2018). Chinese employees' leadership preferences and the relationship with power distance orientation and core self-evaluation. Frontiers of Business Research in China. 12(1), 1-22.

Lin, C. H., \& Sun, J. M. (2013). Personality, value, and leadership preferences of Chinese employees. Academy of Management Proceedings, 2013(1), 15457-15457.

Ling, W., Chia, R. C., \& Fang, L. (2000). Chinese implicit leadership theory. The Journal of Social Psychology, 140(6), 729-739.

Lipsey, M. W. (1990). Design Sensitivity. Sage.

Lisbon, E. I. (2010). A study of leadership preferences by generation. (Doctoral dissertation). Available from ProQuest Dissertations \& Theses Global database. (UMI No. 3455137)

Lu, L., \& Kao, S. F. (2002). Traditional and modern characteristics across the generations: Similarities and discrepancies. The Journal of Social Psychology, 142(1), 45-59.

Lyons, S., \& Kuron, L. (2014). Generational differences in the workplace: A review of the evidence and directions for future research. Journal of Organizational Behavior, 35(S1), S139-S157.

Macky, K., Gardner, D., \& Forsyth, S. (2008). Generational differences at work: Introduction and overview. Journal of Managerial Psychology, 23(8), 857-861.

Mannheim, K. (1970). The problem of generations. Psychoanalytic Review, 57(3), 378-404.

Maslow, A. (1954). Motivation and Personality. Harper. 
McCrum-Gardner, E. (2008). Which is the correct statistical test to use?. British Journal of Oral and Maxillofacial Surgery, 46(1), 38-41.

McHugh, K. E. (2007). Generational consciousness and retirement communities. Population, Space and Place, 13(4), 293-306.

McLeod, S. (2018). Questionnaire: Definition, examples, design and types. Simply Psychology. Available from https://www.simplypsychology.org

Moan, K., \& Hetland, H. (2012). Are leadership preferences universally endorsed or culturally contingent. Scandinavian Journal of Organizational Psychology, 4(1), 522.

Oc, B. (2018). Contextual leadership: A systematic review of how contextual factors shape leadership and its outcomes. The Leadership Quarterly, 29(1), 218-235.

Odumeru, J. A., \& Ogbonna, I. G. (2013). Transformational vs. transactional leadership theories: Evidence in literature. International Review of Management and Business Research, 2(2), 355-361.

Parry, E., \& Urwin, P. (2011). Generational differences in work values: A review of theory and evidence. International Journal of Management Reviews, 13(1), 79-96.

Patton, M. Q. (2002). Qualitative research \& evaluation methods: Integrating theory and practice (3th ed.). Sage publications.

Phillips, J. S., \& Lord, R. G. (1986). Notes on the practical and theoretical consequences of implicit leadership theories for the future of leadership measurement. Journal of Management, 12(1), 31-41.

Ren, S., Xie, Y., Zhu, Y., \& Warner, M. (2018). New generation employees' preferences towards leadership style in China. Asia Pacific Business Review, 24(4), 437-458.

Rhodes, S. R. (1983). Age-related differences in work attitudes and behavior: A review and conceptual analysis. Psychological Bulletin, 93(2), 328-367.

Romar, E. J. (2002). Virtue is good business: Confucianism as a practical business ethics. Journal of Business Ethics, 38(1-2), 119-131.

Rudolph, C. W., \& Zacher, H. (2017). Considering generations from a lifespan developmental perspective. Work, Aging and Retirement, 3(2), 113-129.

Rudolph, C. W., Rauvola, R. S., \& Zacher, H. (2018). Leadership and generations at work: A critical review. The Leadership Quarterly, 29(1), 44-57.

Schoel, C., Bluemke, M., Mueller, P., \& Stahlberg, D. (2011). When autocratic leaders become an option-Uncertainty and self-esteem predict implicit leadership preferences. Journal of Personality and Social Psychology, 101(3), 521-540. 
Sessa, V. I., Kabacoff, R. I., Deal, J., \& Brown, H. (2007). Generational differences in leader values and leadership behaviors. The Psychologist-Manager Journal, 10(1), 47-74.

Stebbins, R. A. (2001). Exploratory Research in the Social Sciences (Vol. 48). Sage.

Sun, J., \& Wang, X. (2010). Value differences between generations in China: A study in Shanghai. Journal of Youth Studies, 13(1), 65-81.

Tapscott, D. (2008). Grown Up Digital. McGraw-Hill Education.

Tulgan, B. (2004). Trends point to a dramatic generational shift in the future workforce. Employment Relations Today, 30(4), 23-31.

Twenge, J. M. (2010). A review of the empirical evidence on generational differences in work attitudes. Journal of Business and Psychology, 25(2), 201-210.

Walker, A. (1993). Intergenerational relations and welfare restructuring: The social construction of an intergenerational problem. In Bengtson, V. L., \& Achenbaum, W. A. (Eds.), The changing contract across generations (pp. 141-165). New York: Transaction Publishers.

Westerman, J. W., \& Yamamura, J. H. (2007). Generational preferences for work environment fit: Effects on employee outcomes. Career Development International, $12(2), 150-161$.

Wey Smola, K., \& Sutton, C. D. (2002). Generational differences: Revisiting generational work values for the new millennium. Journal of Organizational Behavior, 23(4), 363 382.

Wilson, B., Squires, M. A. E., Widger, K., Cranley, L., \& Tourangeau, A. N. N. (2008). Job satisfaction among a multigenerational nursing workforce. Journal of Nursing Management, 16(6), 716-723.

Wong, K. C. (2001). Chinese culture and leadership. International Journal of Leadership in Education, 4(4), 309-319.

Xie, Y. H., \& Chen, J. (2014). Influence of need for employee involvement on new generation employees' leadership preference. Chinese Journal of Management, 11, 1326-1332.

Yang, J., Yu, C. S., \& Wu, J. (2018). Work values across generations in China. Chinese Management Studies, 12(3), 486-505.

Yen, H. C. (2015). Human nature and learning in ancient China. In Hsu, S., \& Wu, Y. Y. (Eds.), Education as cultivation in Chinese culture (pp. 19-43). Singapore: Springer.

Yi, X., Ribbens, B., \& Morgan, C. N. (2010). Generational differences in China: Career implications. Career Development International, 15(6), 601-620. 
Yi, X., Ribbens, B., Fu, L., \& Cheng, W. (2015). Variation in career and workplace attitudes by generation, gender, and culture differences in career perceptions in the United States and China. Employee Relations, 37(1), 66-82.

Yu, H. C., \& Miller, P. (2005). Leadership style: The X Generation and Baby Boomers compared in different cultural contexts. Leadership and Organization Development Journal, 26(1), 35-50.

Zemke, R., Raines, C., \& Filipczak, B. (2000). Generations at work: Managing the clash of Veterans, Boomers, Xers, and Nexters in your workplace. New York: Amacom.

Zhao, Y. (2018). Managing Chinese Millennial employees and their impact on human resource management transformation: An empirical study. Asia Pacific Business Review, 24(4), 472-489.

Zhao, Y., \& Xu, Q. (2019). Understanding the achieving styles of Chinese Millennials and implications on HRM policy. International Journal of Manpower, 41(3), 303-317. 
APPENDIX A

Full Results of Independent Samples T-Test between Chinese Millennials and non-

Millennials

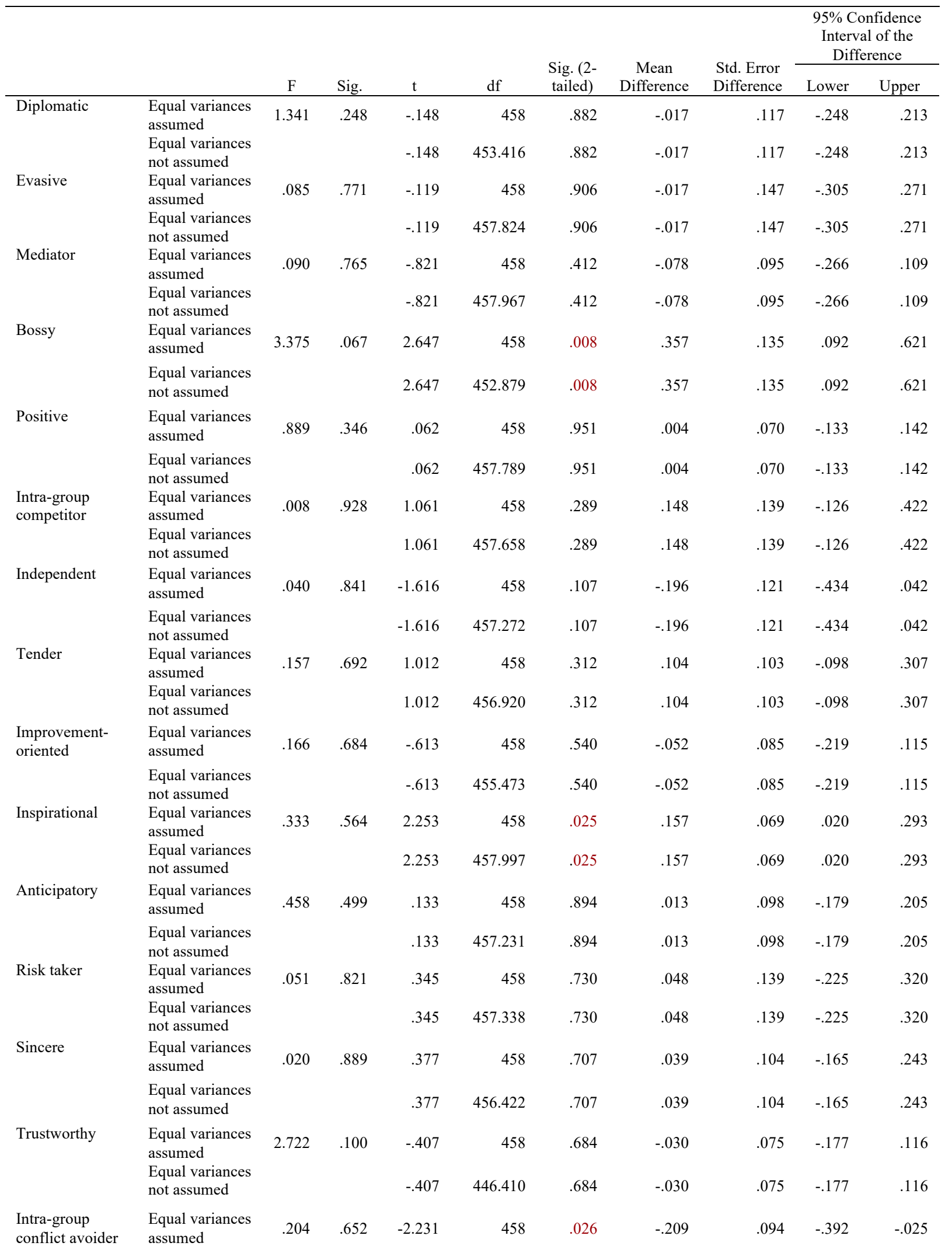




\begin{tabular}{|c|c|c|c|c|c|c|c|c|c|c|}
\hline & $\begin{array}{l}\text { Equal variances } \\
\text { not assumed }\end{array}$ & & & -2.231 & 457.780 & .026 & -.209 & .094 & -.392 & -.025 \\
\hline \multirow[t]{2}{*}{$\begin{array}{l}\text { Administratively } \\
\text { skilled }\end{array}$} & $\begin{array}{l}\text { Equal variances } \\
\text { assumed }\end{array}$ & 3.359 & .067 & -1.838 & 458 & .067 & -.139 & .076 & -.288 & .010 \\
\hline & $\begin{array}{l}\text { Equal variances } \\
\text { not assumed }\end{array}$ & & & -1.838 & 442.181 & .067 & -.139 & .076 & -.288 & .010 \\
\hline \multirow[t]{2}{*}{$\begin{array}{l}\text { Win/win } \\
\text { problem solver }\end{array}$} & $\begin{array}{l}\text { Equal variances } \\
\text { assumed }\end{array}$ & 1.221 & .270 & -.485 & 458 & .628 & -.043 & .090 & -.220 & .133 \\
\hline & $\begin{array}{l}\text { Equal variances } \\
\text { not assumed }\end{array}$ & & & -.485 & 453.731 & .628 & -.043 & .090 & -.220 & .133 \\
\hline \multirow[t]{2}{*}{ Clear } & $\begin{array}{l}\text { Equal variances } \\
\text { assumed }\end{array}$ & .828 & .363 & -1.345 & 458 & .179 & -.126 & .094 & -.310 & .058 \\
\hline & $\begin{array}{l}\text { Equal variances } \\
\text { not assumed }\end{array}$ & & & -1.345 & 453.971 & .179 & -.126 & .094 & -.310 & .058 \\
\hline \multirow[t]{2}{*}{ Self-interested } & $\begin{array}{l}\text { Equal variances } \\
\text { assumed }\end{array}$ & .010 & .918 & -.942 & 458 & .347 & -.100 & .106 & -.309 & .109 \\
\hline & $\begin{array}{l}\text { Equal variances } \\
\text { not assumed }\end{array}$ & & & -.942 & 457.672 & .347 & -.100 & .106 & -.309 & .109 \\
\hline \multirow[t]{2}{*}{ Loyal } & $\begin{array}{l}\text { Equal variances } \\
\text { assumed }\end{array}$ & .045 & .832 & .136 & 458 & .892 & .013 & .096 & -.175 & .201 \\
\hline & $\begin{array}{l}\text { Equal variances } \\
\text { not assumed }\end{array}$ & & & .136 & 457.938 & .892 & .013 & .096 & -.175 & .201 \\
\hline \multirow[t]{2}{*}{ Collaborative } & $\begin{array}{l}\text { Equal variances } \\
\text { assumed }\end{array}$ & .079 & .778 & -1.399 & 458 & .163 & -.117 & .084 & -.282 & .048 \\
\hline & $\begin{array}{l}\text { Equal variances } \\
\text { not assumed }\end{array}$ & & & -1.399 & 452.128 & .163 & -.117 & .084 & -.282 & .048 \\
\hline \multirow[t]{2}{*}{ Encouraging } & $\begin{array}{l}\text { Equal variances } \\
\text { assumed }\end{array}$ & .049 & .825 & .504 & 458 & .614 & .043 & .086 & -.126 & .213 \\
\hline & $\begin{array}{l}\text { Equal variances } \\
\text { not assumed }\end{array}$ & & & .504 & 457.607 & .614 & .043 & .086 & -.126 & .213 \\
\hline \multirow[t]{2}{*}{ Orderly } & $\begin{array}{l}\text { Equal variances } \\
\text { assumed }\end{array}$ & .713 & .399 & -2.330 & 458 & .020 & -.187 & .080 & -.345 & -.029 \\
\hline & $\begin{array}{l}\text { Equal variances } \\
\text { not assumed }\end{array}$ & & & -2.330 & 454.533 & .020 & -.187 & .080 & -.345 & -.029 \\
\hline \multirow[t]{2}{*}{ Autocratic } & $\begin{array}{l}\text { Equal variances } \\
\text { assumed }\end{array}$ & .196 & .658 & -.125 & 458 & .901 & -.017 & .139 & -.291 & .256 \\
\hline & $\begin{array}{l}\text { Equal variances } \\
\text { not assumed }\end{array}$ & & & -.125 & 456.562 & .901 & -.017 & .139 & -.291 & .256 \\
\hline \multirow[t]{2}{*}{ Secretive } & $\begin{array}{l}\text { Equal variances } \\
\text { assumed }\end{array}$ & 3.329 & .069 & 1.154 & 458 & .249 & .143 & .124 & -.101 & .388 \\
\hline & $\begin{array}{l}\text { Equal variances } \\
\text { not assumed }\end{array}$ & & & 1.154 & 453.731 & .249 & .143 & .124 & -.101 & .388 \\
\hline \multirow[t]{2}{*}{ Fraternal } & $\begin{array}{l}\text { Equal variances } \\
\text { assumed }\end{array}$ & .491 & .484 & .208 & 458 & .836 & .026 & .126 & -.221 & .273 \\
\hline & $\begin{array}{l}\text { Equal variances } \\
\text { not assumed }\end{array}$ & & & .208 & 457.240 & .836 & .026 & .126 & -.221 & .273 \\
\hline \multirow[t]{2}{*}{ Generous } & $\begin{array}{l}\text { Equal variances } \\
\text { assumed }\end{array}$ & .014 & .908 & -.167 & 458 & .868 & -.017 & .104 & -.222 & .188 \\
\hline & $\begin{array}{l}\text { Equal variances } \\
\text { not assumed }\end{array}$ & & & -.167 & 457.731 & .868 & -.017 & .104 & -.222 & .188 \\
\hline \multirow[t]{2}{*}{ Formal } & $\begin{array}{l}\text { Equal variances } \\
\text { assumed }\end{array}$ & .918 & .338 & .158 & 458 & .875 & .017 & .110 & -.200 & .234 \\
\hline & $\begin{array}{l}\text { Equal variances } \\
\text { not assumed }\end{array}$ & & & .158 & 455.407 & .875 & .017 & .110 & -.200 & .234 \\
\hline \multirow[t]{2}{*}{ Modest } & $\begin{array}{l}\text { Equal variances } \\
\text { assumed }\end{array}$ & 4.651 & .032 & -2.111 & 458 & .035 & -.200 & .095 & -.386 & -.014 \\
\hline & $\begin{array}{l}\text { Equal variances } \\
\text { not assumed }\end{array}$ & & & -2.111 & 453.325 & .035 & -.200 & .095 & -.386 & -.014 \\
\hline \multirow[t]{2}{*}{ Intelligent } & $\begin{array}{l}\text { Equal variances } \\
\text { assumed }\end{array}$ & .461 & .498 & .457 & 458 & .648 & .035 & .076 & -.115 & .184 \\
\hline & $\begin{array}{l}\text { Equal variances } \\
\text { not assumed }\end{array}$ & & & .457 & 457.965 & .648 & .035 & .076 & -.115 & .184 \\
\hline \multirow[t]{2}{*}{ Decisive } & $\begin{array}{l}\text { Equal variances } \\
\text { assumed }\end{array}$ & .404 & .525 & .574 & 458 & .566 & .052 & .091 & -.126 & .231 \\
\hline & $\begin{array}{l}\text { Equal variances } \\
\text { not assumed }\end{array}$ & & & .574 & 456.357 & .566 & .052 & .091 & -.126 & .231 \\
\hline
\end{tabular}




\begin{tabular}{|c|c|c|c|c|c|c|c|c|c|c|}
\hline Consultative & $\begin{array}{l}\text { Equal variances } \\
\text { assumed } \\
\text { Equal variances } \\
\text { not assumed }\end{array}$ & .017 & .896 & -1.037 & 457.952 & .300 & $\begin{array}{l}-.104 \\
-.104\end{array}$ & .101 & $\begin{array}{l}-.302 \\
-.302\end{array}$ & .093 \\
\hline Enthusiastic & $\begin{array}{l}\text { Equal variances } \\
\text { assumed } \\
\text { Equal variances } \\
\text { not assumed }\end{array}$ & .237 & .626 & $\begin{array}{l}-.053 \\
-.053\end{array}$ & 457.239 & .958 & $\begin{array}{l}-.004 \\
-.004\end{array}$ & .082 & $\begin{array}{l}-.166 \\
-.166\end{array}$ & .157 \\
\hline Risk averse & $\begin{array}{l}\text { Equal variances } \\
\text { assumed } \\
\text { Equal variances } \\
\text { not assumed }\end{array}$ & .144 & .705 & 1.101 & 458.000 & .272 & .139 & .126 & $\begin{array}{l}-.109 \\
-.109\end{array}$ & .388 \\
\hline Compassionate & $\begin{array}{l}\text { Equal variances } \\
\text { assumed } \\
\text { Equal variances } \\
\text { not assumed }\end{array}$ & 2.118 & .146 & 1.190 & 457.365 & .235 & .135 & .113 & $\begin{array}{l}-.088 \\
-.088\end{array}$ & .357 \\
\hline Egocentric & $\begin{array}{l}\text { Equal variances } \\
\text { assumed } \\
\text { Equal variances } \\
\text { not assumed }\end{array}$ & 1.265 & .261 & .980 & 455.521 & .327 & $\begin{array}{l}.122 \\
.122\end{array}$ & .124 & $\begin{array}{l}-.122 \\
-.122\end{array}$ & $\begin{array}{l}.366 \\
.366\end{array}$ \\
\hline Non-explicit & $\begin{array}{l}\text { Equal variances } \\
\text { assumed } \\
\text { Equal variances } \\
\text { not assumed }\end{array}$ & 1.824 & .177 & 2.704 & 453.267 & .007 & .339 & .125 & .093 & $\begin{array}{l}.586 \\
.586\end{array}$ \\
\hline Distant & $\begin{array}{l}\text { Equal variances } \\
\text { assumed } \\
\text { Equal variances } \\
\text { not assumed }\end{array}$ & .014 & .905 & 1.726 & 457.860 & .085 & .222 & .129 & $\begin{array}{l}-.031 \\
-.031\end{array}$ & .474 \\
\hline Cautious & $\begin{array}{l}\text { Equal variances } \\
\text { assumed } \\
\text { Equal variances } \\
\text { not assumed }\end{array}$ & 3.520 & .061 & 2.284 & 450.430 & .023 & .270 & .118 & .038 & $\begin{array}{l}.502 \\
.502\end{array}$ \\
\hline Organized & $\begin{array}{l}\text { Equal variances } \\
\text { assumed } \\
\text { Equal variances } \\
\text { not assumed }\end{array}$ & .076 & .782 & -.397 & 457.961 & .691 & $\begin{array}{l}-.030 \\
-.030\end{array}$ & .077 & $\begin{array}{l}-.181 \\
-.181\end{array}$ & .120 \\
\hline Informed & $\begin{array}{l}\text { Equal variances } \\
\text { assumed } \\
\text { Equal variances } \\
\text { not assumed }\end{array}$ & .789 & .375 & $\begin{array}{l}-1.353 \\
-1.353\end{array}$ & 451.596 & .177 & $\begin{array}{l}-.117 \\
-.117\end{array}$ & .087 & $\begin{array}{l}-.288 \\
-.288\end{array}$ & .053 \\
\hline Logical & $\begin{array}{l}\text { Equal variances } \\
\text { assumed } \\
\text { Equal variances } \\
\text { not assumed }\end{array}$ & 1.604 & .206 & -1.455 & 446.971 & .146 & $\begin{array}{l}-.109 \\
-.109\end{array}$ & .075 & $\begin{array}{l}-.255 \\
-.255\end{array}$ & $\begin{array}{l}.038 \\
.038\end{array}$ \\
\hline Sensitive & $\begin{array}{l}\text { Equal variances } \\
\text { assumed } \\
\text { Equal variances } \\
\text { not assumed }\end{array}$ & 6.733 & .010 & -1.785 & 452.480 & .075 & $\begin{array}{l}-.178 \\
-.178\end{array}$ & .100 & $\begin{array}{l}-.374 \\
-.374\end{array}$ & .018 \\
\hline Communicative & $\begin{array}{l}\text { Equal variances } \\
\text { assumed } \\
\text { Equal variances } \\
\text { not assumed }\end{array}$ & .856 & .355 & -.050 & 454.135 & .960 & $\begin{array}{l}-.004 \\
-.004\end{array}$ & .087 & $\begin{array}{l}-.176 \\
-.176\end{array}$ & .167 \\
\hline Procedural & $\begin{array}{l}\text { Equal variances } \\
\text { assumed } \\
\text { Equal variances } \\
\text { not assumed }\end{array}$ & .546 & .460 & 1.668 & 457.632 & .096 & .209 & .125 & $\begin{array}{l}-.037 \\
-.037\end{array}$ & .455 \\
\hline Class-conscious & $\begin{array}{l}\text { Equal variances } \\
\text { assumed } \\
\text { Equal variances } \\
\text { not assumed }\end{array}$ & 1.473 & .225 & .079 & 456.124 & .937 & .013 & .165 & $\begin{array}{l}-.311 \\
-.311\end{array}$ & .337 \\
\hline Self-sacrificial & $\begin{array}{l}\text { Equal variances } \\
\text { assumed } \\
\text { Equal variances } \\
\text { not assumed }\end{array}$ & 2.149 & .143 & 1.285 & 455.631 & .199 & .174 & .135 & $\begin{array}{l}-.092 \\
-.092\end{array}$ & .440 \\
\hline
\end{tabular}




\begin{tabular}{|c|c|c|c|c|c|c|c|c|c|c|}
\hline \multirow[t]{2}{*}{ Patient } & $\begin{array}{l}\text { Equal variances } \\
\text { assumed }\end{array}$ & 2.171 & .141 & -1.123 & 458 & .262 & -.100 & .089 & -.275 & .075 \\
\hline & $\begin{array}{l}\text { Equal variances } \\
\text { not assumed }\end{array}$ & & & -1.123 & 457.338 & .262 & -.100 & .089 & -.275 & .075 \\
\hline \multirow[t]{2}{*}{ Honest } & $\begin{array}{l}\text { Equal variances } \\
\text { assumed }\end{array}$ & .096 & .756 & .438 & 458 & .662 & .035 & .079 & -.121 & .191 \\
\hline & $\begin{array}{l}\text { Equal variances } \\
\text { not assumed }\end{array}$ & & & .438 & 457.338 & .662 & .035 & .079 & -.121 & .191 \\
\hline \multirow[t]{2}{*}{ Coordinator } & $\begin{array}{l}\text { Equal variances } \\
\text { assumed }\end{array}$ & 2.612 & .107 & -1.243 & 458 & .215 & -.100 & .080 & -.258 & .058 \\
\hline & $\begin{array}{l}\text { Equal variances } \\
\text { not assumed }\end{array}$ & & & -1.243 & 448.326 & .215 & -.100 & .080 & -.258 & .058 \\
\hline \multirow[t]{2}{*}{ Team builder } & $\begin{array}{l}\text { Equal variances } \\
\text { assumed }\end{array}$ & .233 & .630 & .574 & 458 & .566 & .039 & .068 & -.095 & .173 \\
\hline & $\begin{array}{l}\text { Equal variances } \\
\text { not assumed }\end{array}$ & & & .574 & 456.650 & .566 & .039 & .068 & -.095 & .173 \\
\hline \multirow[t]{2}{*}{$\begin{array}{l}\text { Performance- } \\
\text { oriented }\end{array}$} & $\begin{array}{l}\text { Equal variances } \\
\text { assumed }\end{array}$ & .815 & .367 & .440 & 458 & .660 & .048 & .109 & -.166 & .261 \\
\hline & $\begin{array}{l}\text { Equal variances } \\
\text { not assumed }\end{array}$ & & & .440 & 457.999 & .660 & .048 & .109 & -.166 & .261 \\
\hline \multirow[t]{2}{*}{ Ambitious } & $\begin{array}{l}\text { Equal variances } \\
\text { assumed }\end{array}$ & 3.139 & .077 & -2.081 & 458 & .038 & -.209 & .100 & -.406 & -.012 \\
\hline & $\begin{array}{l}\text { Equal variances } \\
\text { not assumed }\end{array}$ & & & -2.081 & 450.620 & .038 & -.209 & .100 & -.406 & -.012 \\
\hline \multirow[t]{2}{*}{ Micro-manager } & $\begin{array}{l}\text { Equal variances } \\
\text { assumed }\end{array}$ & .396 & .529 & -1.813 & 458 & .070 & -.270 & .149 & -.562 & .023 \\
\hline & $\begin{array}{l}\text { Equal variances } \\
\text { not assumed }\end{array}$ & & & -1.813 & 455.776 & .070 & -.270 & .149 & -.562 & .023 \\
\hline \multirow[t]{2}{*}{$\begin{array}{l}\text { Avoids } \\
\text { negatives }\end{array}$} & $\begin{array}{l}\text { Equal variances } \\
\text { assumed }\end{array}$ & .020 & .888 & 1.028 & 458 & .304 & .148 & .144 & -.135 & .430 \\
\hline & $\begin{array}{l}\text { Equal variances } \\
\text { not assumed }\end{array}$ & & & 1.028 & 457.912 & .304 & .148 & .144 & -.135 & .430 \\
\hline
\end{tabular}


APPENDIX B

Full Results of One-way ANOVA between Chinese Millennials and Non-Millennials

\begin{tabular}{|c|c|c|c|c|c|c|}
\hline & & $\begin{array}{l}\text { Sum of } \\
\text { Squares }\end{array}$ & df & Mean Square & $\mathrm{F}$ & Sig. \\
\hline \multirow[t]{3}{*}{ Diplomatic } & \multirow{3}{*}{$\begin{array}{l}\text { Between Groups } \\
\text { Within Groups } \\
\text { Total }\end{array}$} & 4.603 & 4 & 1.151 & \multirow[t]{3}{*}{.727} & \multirow[t]{3}{*}{.574} \\
\hline & & 720.519 & 455 & 1.584 & & \\
\hline & & 725.122 & 459 & & & \\
\hline \multirow[t]{3}{*}{ Evasive } & Between Groups & 3.975 & 4 & 0.994 & \multirow[t]{3}{*}{.401} & \multirow[t]{3}{*}{.808} \\
\hline & Within Groups & 1126.599 & 455 & 2.476 & & \\
\hline & Total & 1130.574 & 459 & & & \\
\hline \multirow[t]{3}{*}{ Mediator } & Between Groups & 6.984 & 4 & 1.746 & \multirow[t]{3}{*}{1.681} & \multirow[t]{3}{*}{.153} \\
\hline & Within Groups & 472.460 & 455 & 1.038 & & \\
\hline & Total & 479.443 & 459 & & & \\
\hline \multirow{3}{*}{ Bossy } & Between Groups & 16.426 & 4 & 4.107 & \multirow{3}{*}{1.959} & \multirow[t]{3}{*}{.100} \\
\hline & Within Groups & 953.956 & 455 & 2.097 & & \\
\hline & Total & 970.383 & 459 & & & \\
\hline \multirow[t]{3}{*}{ Positive } & Between Groups & 1.347 & 4 & .337 & \multirow[t]{3}{*}{.595} & \multirow[t]{3}{*}{.666} \\
\hline & Within Groups & 257.477 & 455 & .566 & & \\
\hline & Total & 258.824 & 459 & & & \\
\hline \multirow[t]{3}{*}{ Intra-group competitor } & Between Groups & 36.880 & 4 & 9.220 & 4.247 & .002 \\
\hline & Within Groups & 987.694 & 455 & 2.171 & & \\
\hline & Total & 1024.574 & 459 & & & \\
\hline Independent & Between Groups & 5.631 & 4 & 1.408 & .831 & .506 \\
\hline & Within Groups & 770.966 & 455 & 1.694 & & \\
\hline & Total & 776.598 & 459 & & & \\
\hline Tender & Between Groups & 9.224 & 4 & 2.306 & 1.899 & .109 \\
\hline & Within Groups & 552.463 & 455 & 1.214 & & \\
\hline & Total & 561.687 & 459 & & & \\
\hline Improvement-oriented & Between Groups & 2.513 & 4 & .628 & .753 & .556 \\
\hline & Within Groups & 379.531 & 455 & .834 & & \\
\hline & Total & 382.043 & 459 & & & \\
\hline Inspirational & Between Groups & 3.742 & 4 & .936 & 1.681 & .153 \\
\hline & Within Groups & 253.301 & 455 & .557 & & \\
\hline & Total & 257.043 & 459 & & & \\
\hline Anticipatory & Between Groups & 6.370 & 4 & 1.592 & 1.458 & .214 \\
\hline & Within Groups & 497.045 & 455 & 1.092 & & \\
\hline & Total & 503.415 & 459 & & & \\
\hline Risk taker & Between Groups & 9.342 & 4 & 2.336 & 1.059 & .376 \\
\hline & Within Groups & 1003.569 & 455 & 2.206 & & \\
\hline & Total & 1012.911 & 459 & & & \\
\hline Sincere & Between Groups & 2.301 & 4 & .575 & .462 & .764 \\
\hline & Within Groups & 566.436 & 455 & 1.245 & & \\
\hline & Total & 568.737 & 459 & & & \\
\hline Trustworthy & Between Groups & 1.445 & 4 & .361 & .562 & 690 \\
\hline & Within Groups & 292.596 & 455 & .643 & & \\
\hline & Total & 294.041 & 459 & & & \\
\hline Intra-group conflict & Between Groups & 5.843 & 4 & 1.461 & 1.445 & .218 \\
\hline avoider & Within Groups & 459.844 & 455 & 1.011 & & \\
\hline & Total & 465.687 & 459 & & & \\
\hline Administratively skilled & Between Groups & 5.141 & 4 & 1.285 & 1.956 & .100 \\
\hline & Within Groups & 298.955 & 455 & .657 & & \\
\hline & Total & 304.096 & 459 & & & \\
\hline Win/win problem solver & Between Groups & .944 & 4 & .236 & .254 & .907 \\
\hline & Within Groups & 422.404 & 455 & .928 & & \\
\hline & Total & 423.348 & 459 & & & \\
\hline Clear & Between Groups & 8.245 & 4 & 2.061 & 2.054 & .086 \\
\hline & Within Groups & 456.700 & 455 & 1.004 & & \\
\hline & Total & 464.946 & 459 & & & \\
\hline Self-interested & Between Groups & 4.135 & 4 & 1.034 & .797 & .528 \\
\hline & Within Groups & 590.515 & 455 & 1.298 & & \\
\hline & Total & 594.650 & 459 & & & \\
\hline
\end{tabular}




\begin{tabular}{|c|c|c|c|c|c|c|}
\hline Loyal & Between Groups & 3.816 & 4 & 0.954 & .908 & .459 \\
\hline & Within Groups & 478.294 & 455 & 1.051 & & \\
\hline & Total & 482.111 & 459 & & & \\
\hline Collaborative & Between Groups & 8.081 & 4 & 2.020 & 2.522 & .040 \\
\hline & Within Groups & 364.517 & 455 & .801 & & \\
\hline & Total & 372.598 & 459 & & & \\
\hline Encouraging & Between Groups & 1.024 & 4 & .256 & .298 & 879 \\
\hline & Within Groups & 391.063 & 455 & .859 & & \\
\hline & Total & 392.087 & 459 & & & \\
\hline Orderly & Between Groups & 4.269 & 4 & 1.067 & 1.433 & 222 \\
\hline & Within Groups & 338.903 & 455 & .745 & & \\
\hline & Total & 343.172 & 459 & & & \\
\hline Autocratic & Between Groups & 9.003 & 4 & 2.251 & 1.011 & .401 \\
\hline & Within Groups & 1013.179 & 455 & 2.227 & & \\
\hline & Total & 1022.183 & 459 & & & \\
\hline Secretive & Between Groups & 2.770 & 4 & .692 & .387 & .818 \\
\hline & Within Groups & 814.124 & 455 & 1.789 & & \\
\hline & Total & 816.893 & 459 & & & \\
\hline Fraternal & Between Groups & .899 & 4 & .225 & .123 & .974 \\
\hline & Within Groups & 831.197 & 455 & 1.827 & & \\
\hline & Total & 832.096 & 459 & & & \\
\hline Generous & Between Groups & .301 & 4 & .075 & .060 & 993 \\
\hline & Within Groups & 572.621 & 455 & 1.259 & & \\
\hline & Total & 572.922 & 459 & & & \\
\hline Formal & Between Groups & 3.847 & 4 & 0.962 & .686 & 602 \\
\hline & Within Groups & 637.901 & 455 & 1.402 & & \\
\hline & Total & 641.748 & 459 & & & \\
\hline Modest & Between Groups & 6.059 & 4 & 1.515 & 1.463 & 213 \\
\hline & Within Groups & 471.202 & 455 & 1.036 & & \\
\hline & Total & 477.261 & 459 & & & \\
\hline Intelligent & Between Groups & 1.943 & 4 & 486 & .729 & .572 \\
\hline & Within Groups & 303.022 & 455 & 666 & & \\
\hline & Total & 304.965 & 459 & & & \\
\hline Decisive & Between Groups & 1.974 & 4 & 493 & .519 & .722 \\
\hline & Within Groups & 432.800 & 455 & 951 & & \\
\hline & Total & 434.774 & 459 & & & \\
\hline Consultative & Between Groups & 4.972 & 4 & 1.243 & 1.068 & .372 \\
\hline & Within Groups & 529.602 & 455 & 1.164 & & \\
\hline & Total & 534.574 & 459 & & & \\
\hline Enthusiastic & Between Groups & 2.087 & 4 & .522 & .669 & .614 \\
\hline & Within Groups & 354.737 & 455 & .780 & & \\
\hline & Total & 356.824 & 459 & & & \\
\hline Risk averse & Between Groups & 3.843 & 4 & 0.961 & .521 & .721 \\
\hline & Within Groups & 839.852 & 455 & 1.846 & & \\
\hline & Total & 843.696 & 459 & & & \\
\hline Compassionate & Between Groups & 3.504 & 4 & 0.876 & .591 & .669 \\
\hline & Within Groups & 673.911 & 455 & 1.481 & & \\
\hline & Total & 677.415 & 459 & & & \\
\hline Egocentric & Between Groups & 9.094 & 4 & 2.273 & 1.285 & .275 \\
\hline & Within Groups & 805.028 & 455 & 1.769 & & \\
\hline & Total & 814.122 & 459 & & & \\
\hline Non-explicit & Between Groups & 14.653 & 4 & 3.663 & 2.015 & .091 \\
\hline & Within Groups & 827.095 & 455 & 1.818 & & \\
\hline & Total & 841.748 & 459 & & & \\
\hline Distant & Between Groups & 15.570 & 4 & 3.893 & 2.060 & .085 \\
\hline & Within Groups & 859.845 & 455 & 1.890 & & \\
\hline & Total & 875.415 & 459 & & & \\
\hline Cautious & Between Groups & 17.019 & 4 & 4.255 & 2.669 & .032 \\
\hline & Within Groups & 725.277 & 455 & 1.594 & & \\
\hline & Total & 742.296 & 459 & & & \\
\hline Organized & Between Groups & .325 & 4 & 081 & .120 & .975 \\
\hline & Within Groups & 308.621 & 455 & .678 & & \\
\hline & Total & 308.946 & 459 & & & \\
\hline
\end{tabular}




\begin{tabular}{|c|c|c|c|c|c|c|}
\hline \multirow[t]{3}{*}{ Informed } & \multirow{3}{*}{$\begin{array}{l}\text { Between Groups } \\
\text { Within Groups } \\
\text { Total }\end{array}$} & 2.928 & 4 & .732 & \multirow[t]{3}{*}{.843} & \multirow[t]{3}{*}{.499} \\
\hline & & 395.287 & 455 & .869 & & \\
\hline & & 398.215 & 459 & & & \\
\hline \multirow[t]{3}{*}{ Logical } & \multirow{3}{*}{$\begin{array}{l}\text { Between Groups } \\
\text { Within Groups } \\
\text { Total }\end{array}$} & 4.972 & 4 & 1.243 & \multirow[t]{3}{*}{1.949} & \multirow[t]{3}{*}{.101} \\
\hline & & 290.200 & 455 & .638 & & \\
\hline & & 295.172 & 459 & & & \\
\hline \multirow[t]{3}{*}{ Sensitive } & \multirow{3}{*}{$\begin{array}{l}\text { Between Groups } \\
\text { Within Groups } \\
\text { Total }\end{array}$} & 5.410 & 4 & 1.352 & \multirow[t]{3}{*}{1.176} & \multirow[t]{3}{*}{.321} \\
\hline & & 523.414 & 455 & 1.150 & & \\
\hline & & 528.824 & 459 & & & \\
\hline \multirow[t]{3}{*}{ Communicative } & Between Groups & 2.378 & 4 & .594 & \multirow[t]{3}{*}{.677} & \multirow[t]{3}{*}{.608} \\
\hline & Within Groups & 399.664 & 455 & .878 & & \\
\hline & Total & 402.041 & 459 & & & \\
\hline \multirow[t]{3}{*}{ Procedural } & Between Groups & 11.571 & 4 & 2.893 & \multirow[t]{3}{*}{1.608} & \multirow[t]{3}{*}{.171} \\
\hline & Within Groups & 818.377 & 455 & 1.799 & & \\
\hline & Total & 829.948 & 459 & & & \\
\hline \multirow[t]{3}{*}{ Class-conscious } & Between Groups & 8.825 & 4 & 2.206 & \multirow[t]{3}{*}{.705} & \multirow[t]{3}{*}{.589} \\
\hline & Within Groups & 1423.721 & 455 & 3.129 & & \\
\hline & Total & 1432.546 & 459 & & & \\
\hline \multirow[t]{3}{*}{ Self-sacrificial } & Between Groups & 22.616 & 4 & 5.654 & \multirow[t]{3}{*}{2.721} & .029 \\
\hline & Within Groups & 945.558 & 455 & 2.078 & & \\
\hline & Total & 968.174 & 459 & & & \\
\hline Patient & Between Groups & 3.594 & 4 & 0.899 & 0.984 & .416 \\
\hline & Within Groups & 415.404 & 455 & .913 & & \\
\hline & Total & 418.998 & 459 & & & \\
\hline Honest & Between Groups & .885 & 4 & .221 & .304 & .876 \\
\hline & Within Groups & 331.559 & 455 & .729 & & \\
\hline & Total & 332.443 & 459 & & & \\
\hline Coordinator & Between Groups & 4.505 & 4 & 1.126 & 1.517 & .196 \\
\hline & Within Groups & 337.710 & 455 & .742 & & \\
\hline & Total & 342.215 & 459 & & & \\
\hline Team builder & Between Groups & 1.126 & 4 & .281 & .526 & .717 \\
\hline & Within Groups & 243.507 & 455 & .535 & & \\
\hline & Total & 244.633 & 459 & & & \\
\hline Performance-oriented & Between Groups & 5.903 & 4 & 1.476 & 1.088 & .362 \\
\hline & Within Groups & 617.043 & 455 & 1.356 & & \\
\hline & Total & 622.946 & 459 & & & \\
\hline Ambitious & Between Groups & 7.142 & 4 & 1.786 & 1.540 & .190 \\
\hline & Within Groups & 527.606 & 455 & 1.160 & & \\
\hline & Total & 534.748 & 459 & & & \\
\hline Micro-manager & Between Groups & 18.398 & 4 & 4.600 & 1.813 & .125 \\
\hline & Within Groups & 1154.393 & 455 & 2.537 & & \\
\hline & Total & 1172.791 & 459 & & & \\
\hline Avoids negatives & Between Groups & 5.583 & 4 & 1.396 & .585 & .674 \\
\hline & Within Groups & 1085.339 & 455 & 2.385 & & \\
\hline & Total & 1090.922 & 459 & & & \\
\hline
\end{tabular}


APPENDIX C

Full Results of Independent Samples t-Test Between the Youngest and Oldest Age Groups

\begin{tabular}{|c|c|c|c|c|c|c|c|c|c|c|}
\hline & & \multirow[b]{2}{*}{$\mathrm{F}$} & \multirow[b]{2}{*}{ Sig. } & \multirow[b]{2}{*}{$\mathrm{t}$} & \multirow[b]{2}{*}{$\mathrm{df}$} & \multirow{2}{*}{$\begin{array}{l}\text { Sig. } \\
(2- \\
\text { tailed })\end{array}$} & \multirow{2}{*}{$\begin{array}{c}\text { Mean } \\
\text { Difference }\end{array}$} & \multirow{2}{*}{$\begin{array}{l}\text { Std. Error } \\
\text { Difference }\end{array}$} & \multicolumn{2}{|c|}{$\begin{array}{l}95 \% \text { Confidence } \\
\text { Interval of the } \\
\text { Difference }\end{array}$} \\
\hline & & & & & & & & & Lower & Upper \\
\hline \multirow[t]{2}{*}{ Diplomatic } & $\begin{array}{l}\text { Equal variances } \\
\text { assumed }\end{array}$ & 0.243 & 0.623 & 0.044 & 165 & 0.965 & 0.012 & 0.268 & -0.517 & 0.540 \\
\hline & $\begin{array}{l}\text { Equal variances } \\
\text { not assumed }\end{array}$ & & & 0.045 & 68.666 & 0.964 & 0.012 & 0.260 & -0.507 & 0.531 \\
\hline \multirow[t]{2}{*}{ Evasive } & $\begin{array}{l}\text { Equal variances } \\
\text { assumed }\end{array}$ & 1.434 & 0.233 & 1.015 & 165 & 0.312 & 0.295 & 0.291 & -0.279 & 0.870 \\
\hline & $\begin{array}{l}\text { Equal variances } \\
\text { not assumed }\end{array}$ & & & 1.069 & 71.435 & 0.289 & 0.295 & 0.276 & -0.255 & 0.846 \\
\hline \multirow[t]{2}{*}{ Mediator } & $\begin{array}{l}\text { Equal variances } \\
\text { assumed }\end{array}$ & 7.369 & 0.007 & 1.498 & 165 & 0.136 & 0.285 & 0.190 & -0.091 & 0.660 \\
\hline & $\begin{array}{l}\text { Equal variances } \\
\text { not assumed }\end{array}$ & & & 1.774 & 90.700 & 0.079 & 0.285 & 0.161 & -0.034 & 0.604 \\
\hline \multirow[t]{2}{*}{ Bossy } & $\begin{array}{l}\text { Equal variances } \\
\text { assumed }\end{array}$ & 0.742 & 0.390 & -1.559 & 165 & 0.121 & -0.446 & 0.286 & -1.011 & 0.119 \\
\hline & $\begin{array}{l}\text { Equal variances } \\
\text { not assumed }\end{array}$ & & & -1.600 & 68.310 & 0.114 & -0.446 & 0.279 & -1.003 & 0.110 \\
\hline \multirow[t]{2}{*}{ Positive } & $\begin{array}{l}\text { Equal variances } \\
\text { assumed }\end{array}$ & 0.211 & 0.647 & -1.048 & 165 & 0.296 & -0.141 & 0.135 & -0.408 & 0.125 \\
\hline & $\begin{array}{l}\text { Equal variances } \\
\text { not assumed }\end{array}$ & & & -0.994 & 60.405 & 0.324 & -0.141 & 0.142 & -0.426 & 0.143 \\
\hline \multirow[t]{2}{*}{$\begin{array}{l}\text { Intra-group } \\
\text { competitor }\end{array}$} & $\begin{array}{l}\text { Equal variances } \\
\text { assumed }\end{array}$ & 2.904 & 0.090 & -3.373 & 165 & 0.001 & -0.933 & 0.277 & -1.480 & -0.387 \\
\hline & $\begin{array}{l}\text { Equal variances } \\
\text { not assumed }\end{array}$ & & & -3.124 & 58.454 & 0.003 & -0.933 & 0.299 & -1.531 & -0.335 \\
\hline \multirow[t]{2}{*}{ Independent } & $\begin{array}{l}\text { Equal variances } \\
\text { assumed }\end{array}$ & 0.204 & 0.652 & 0.849 & 165 & 0.397 & 0.197 & 0.233 & -0.262 & 0.657 \\
\hline & $\begin{array}{l}\text { Equal variances } \\
\text { not assumed }\end{array}$ & & & 0.869 & 67.961 & 0.388 & 0.197 & 0.227 & -0.256 & 0.651 \\
\hline \multirow[t]{2}{*}{ Tender } & $\begin{array}{l}\text { Equal variances } \\
\text { assumed }\end{array}$ & 7.250 & 0.008 & 0.906 & 165 & 0.366 & 0.213 & 0.236 & -0.252 & 0.678 \\
\hline & $\begin{array}{l}\text { Equal variances } \\
\text { not assumed }\end{array}$ & & & 0.795 & 54.623 & 0.430 & 0.213 & 0.268 & -0.324 & 0.751 \\
\hline \multirow[t]{2}{*}{$\begin{array}{l}\text { Improvement- } \\
\text { oriented }\end{array}$} & $\begin{array}{l}\text { Equal variances } \\
\text { assumed }\end{array}$ & 0.081 & 0.777 & 0.509 & 165 & 0.611 & 0.094 & 0.186 & -0.272 & 0.461 \\
\hline & $\begin{array}{l}\text { Equal variances } \\
\text { not assumed }\end{array}$ & & & 0.552 & 75.360 & 0.583 & 0.094 & 0.171 & -0.247 & 0.436 \\
\hline \multirow[t]{2}{*}{ Inspirational } & $\begin{array}{l}\text { Equal variances } \\
\text { assumed }\end{array}$ & 0.328 & 0.568 & -1.859 & 165 & 0.065 & -0.271 & 0.146 & -0.559 & 0.017 \\
\hline & $\begin{array}{l}\text { Equal variances } \\
\text { not assumed }\end{array}$ & & & -1.816 & 63.098 & 0.074 & -0.271 & 0.149 & -0.569 & 0.027 \\
\hline \multirow[t]{2}{*}{ Anticipatory } & $\begin{array}{l}\text { Equal variances } \\
\text { assumed }\end{array}$ & 0.731 & 0.394 & -1.669 & 165 & 0.097 & -0.345 & 0.207 & -0.753 & 0.063 \\
\hline & $\begin{array}{l}\text { Equal variances } \\
\text { not assumed }\end{array}$ & & & -1.558 & 59.048 & 0.125 & -0.345 & 0.221 & -0.788 & 0.098 \\
\hline \multirow[t]{2}{*}{ Risk taker } & $\begin{array}{l}\text { Equal variances } \\
\text { assumed }\end{array}$ & 0.009 & 0.923 & -1.322 & 165 & 0.188 & -0.385 & 0.291 & -0.960 & 0.190 \\
\hline & $\begin{array}{l}\text { Equal variances } \\
\text { not assumed }\end{array}$ & & & -1.371 & 69.500 & 0.175 & -0.385 & 0.281 & -0.945 & 0.175 \\
\hline Sincere & $\begin{array}{l}\text { Equal variances } \\
\text { assumed }\end{array}$ & 0.050 & 0.823 & 0.254 & 165 & 0.800 & 0.053 & 0.208 & -0.358 & 0.464 \\
\hline
\end{tabular}




\begin{tabular}{|c|c|c|c|c|c|c|c|c|c|c|}
\hline & $\begin{array}{l}\text { Equal variances } \\
\text { not assumed }\end{array}$ & & & 0.250 & 63.929 & 0.804 & 0.053 & 0.211 & -0.369 & 0.475 \\
\hline \multirow[t]{2}{*}{ Trustworthy } & $\begin{array}{l}\text { Equal variances } \\
\text { assumed }\end{array}$ & 0.590 & 0.444 & 0.135 & 165 & 0.893 & 0.022 & 0.163 & -0.300 & 0.344 \\
\hline & $\begin{array}{l}\text { Equal variances } \\
\text { not assumed }\end{array}$ & & & 0.153 & 81.861 & 0.879 & 0.022 & 0.144 & -0.265 & 0.309 \\
\hline \multirow[t]{2}{*}{$\begin{array}{l}\text { Intra-group } \\
\text { conflict avoider }\end{array}$} & $\begin{array}{l}\text { Equal variances } \\
\text { assumed }\end{array}$ & 0.551 & 0.459 & 0.751 & 165 & 0.454 & 0.150 & 0.200 & -0.245 & 0.545 \\
\hline & $\begin{array}{l}\text { Equal variances } \\
\text { not assumed }\end{array}$ & & & 0.691 & 57.988 & 0.492 & 0.150 & 0.217 & -0.285 & 0.585 \\
\hline \multirow[t]{2}{*}{$\begin{array}{l}\text { Administratively } \\
\text { skilled }\end{array}$} & $\begin{array}{l}\text { Equal variances } \\
\text { assumed }\end{array}$ & 0.460 & 0.499 & -0.020 & 165 & 0.984 & -0.003 & 0.146 & -0.292 & 0.286 \\
\hline & $\begin{array}{l}\text { Equal variances } \\
\text { not assumed }\end{array}$ & & & -0.020 & 62.766 & 0.984 & -0.003 & 0.150 & -0.303 & 0.297 \\
\hline \multirow[t]{2}{*}{$\begin{array}{l}\text { Win/win problem } \\
\text { solver }\end{array}$} & $\begin{array}{l}\text { Equal variances } \\
\text { assumed }\end{array}$ & 1.648 & 0.201 & 0.617 & 165 & 0.538 & 0.115 & 0.186 & -0.252 & 0.482 \\
\hline & $\begin{array}{l}\text { Equal variances } \\
\text { not assumed }\end{array}$ & & & 0.677 & 77.019 & 0.501 & 0.115 & 0.170 & -0.223 & 0.452 \\
\hline \multirow[t]{2}{*}{ Clear } & $\begin{array}{l}\text { Equal variances } \\
\text { assumed }\end{array}$ & 2.184 & 0.141 & 2.703 & 165 & 0.008 & 0.480 & 0.178 & 0.129 & 0.831 \\
\hline & $\begin{array}{l}\text { Equal variances } \\
\text { not assumed }\end{array}$ & & & 3.201 & 90.785 & 0.002 & 0.480 & 0.150 & 0.182 & 0.778 \\
\hline \multirow[t]{2}{*}{ Self-interested } & $\begin{array}{l}\text { Equal variances } \\
\text { assumed }\end{array}$ & 0.010 & 0.919 & 0.916 & 165 & 0.361 & 0.203 & 0.222 & -0.235 & 0.642 \\
\hline & $\begin{array}{l}\text { Equal variances } \\
\text { not assumed }\end{array}$ & & & 0.903 & 63.948 & 0.370 & 0.203 & 0.225 & -0.247 & 0.653 \\
\hline \multirow[t]{2}{*}{ Loyal } & $\begin{array}{l}\text { Equal variances } \\
\text { assumed }\end{array}$ & 5.310 & 0.022 & 1.451 & 165 & 0.149 & 0.285 & 0.196 & -0.103 & 0.672 \\
\hline & $\begin{array}{l}\text { Equal variances } \\
\text { not assumed }\end{array}$ & & & 1.644 & 82.400 & 0.104 & 0.285 & 0.173 & -0.060 & 0.629 \\
\hline \multirow[t]{2}{*}{ Collaborative } & $\begin{array}{l}\text { Equal variances } \\
\text { assumed }\end{array}$ & 0.830 & 0.364 & 2.094 & 165 & 0.038 & 0.388 & 0.185 & 0.022 & 0.754 \\
\hline & $\begin{array}{l}\text { Equal variances } \\
\text { not assumed }\end{array}$ & & & 2.295 & 77.008 & 0.024 & 0.388 & 0.169 & 0.051 & 0.725 \\
\hline \multirow[t]{2}{*}{ Encouraging } & $\begin{array}{l}\text { Equal variances } \\
\text { assumed }\end{array}$ & 0.220 & 0.640 & 0.457 & 165 & 0.648 & 0.077 & 0.168 & -0.255 & 0.409 \\
\hline & $\begin{array}{l}\text { Equal variances } \\
\text { not assumed }\end{array}$ & & & 0.457 & 65.416 & 0.649 & 0.077 & 0.168 & -0.259 & 0.412 \\
\hline \multirow[t]{2}{*}{ Orderly } & $\begin{array}{l}\text { Equal variances } \\
\text { assumed }\end{array}$ & 1.503 & 0.222 & 1.403 & 165 & 0.162 & 0.225 & 0.161 & -0.092 & 0.543 \\
\hline & $\begin{array}{l}\text { Equal variances } \\
\text { not assumed }\end{array}$ & & & 1.533 & 76.535 & 0.129 & 0.225 & 0.147 & -0.067 & 0.518 \\
\hline \multirow[t]{2}{*}{ Autocratic } & $\begin{array}{l}\text { Equal variances } \\
\text { assumed }\end{array}$ & 0.001 & 0.973 & 1.049 & 165 & 0.296 & 0.303 & 0.289 & -0.267 & 0.873 \\
\hline & $\begin{array}{l}\text { Equal variances } \\
\text { not assumed }\end{array}$ & & & 1.022 & 62.795 & 0.311 & 0.303 & 0.297 & -0.290 & 0.896 \\
\hline \multirow[t]{2}{*}{ Secretive } & $\begin{array}{l}\text { Equal variances } \\
\text { assumed }\end{array}$ & 0.001 & 0.977 & -0.230 & 165 & 0.818 & -0.060 & 0.262 & -0.579 & 0.458 \\
\hline & $\begin{array}{l}\text { Equal variances } \\
\text { not assumed }\end{array}$ & & & -0.226 & 63.632 & 0.822 & -0.060 & 0.267 & -0.594 & 0.473 \\
\hline \multirow[t]{2}{*}{ Fraternal } & $\begin{array}{l}\text { Equal variances } \\
\text { assumed }\end{array}$ & 0.895 & 0.345 & -0.135 & 165 & 0.893 & -0.032 & 0.236 & -0.499 & 0.435 \\
\hline & $\begin{array}{l}\text { Equal variances } \\
\text { not assumed }\end{array}$ & & & -0.142 & 71.192 & 0.888 & -0.032 & 0.225 & -0.480 & 0.416 \\
\hline \multirow[t]{2}{*}{ Generous } & $\begin{array}{l}\text { Equal variances } \\
\text { assumed }\end{array}$ & 0.125 & 0.724 & -0.013 & 165 & 0.990 & -0.003 & 0.203 & -0.404 & 0.399 \\
\hline & $\begin{array}{l}\text { Equal variances } \\
\text { not assumed }\end{array}$ & & & -0.013 & 69.597 & 0.990 & -0.003 & 0.196 & -0.394 & 0.388 \\
\hline
\end{tabular}




\begin{tabular}{|c|c|c|c|c|c|c|c|c|c|c|}
\hline \multirow[t]{2}{*}{ Formal } & $\begin{array}{l}\text { Equal variances } \\
\text { assumed }\end{array}$ & 1.793 & 0.182 & -0.483 & 165 & 0.630 & -0.104 & 0.214 & -0.527 & 0.320 \\
\hline & $\begin{array}{l}\text { Equal variances } \\
\text { not assumed }\end{array}$ & & & -0.452 & 59.238 & 0.653 & -0.104 & 0.229 & -0.562 & 0.355 \\
\hline \multirow[t]{2}{*}{ Modest } & $\begin{array}{l}\text { Equal variances } \\
\text { assumed }\end{array}$ & 1.844 & 0.176 & 1.927 & 165 & 0.056 & 0.384 & 0.199 & -0.009 & 0.778 \\
\hline & $\begin{array}{l}\text { Equal variances } \\
\text { not assumed }\end{array}$ & & & 2.054 & 73.005 & 0.044 & 0.384 & 0.187 & 0.011 & 0.757 \\
\hline \multirow[t]{2}{*}{ Intelligent } & $\begin{array}{l}\text { Equal variances } \\
\text { assumed }\end{array}$ & 0.033 & 0.856 & -0.689 & 165 & 0.492 & -0.095 & 0.138 & -0.368 & 0.177 \\
\hline & $\begin{array}{l}\text { Equal variances } \\
\text { not assumed }\end{array}$ & & & -0.696 & 66.436 & 0.489 & -0.095 & 0.137 & -0.368 & 0.178 \\
\hline \multirow[t]{2}{*}{ Decisive } & $\begin{array}{l}\text { Equal variances } \\
\text { assumed }\end{array}$ & 0.168 & 0.682 & 0.207 & 165 & 0.836 & 0.035 & 0.167 & -0.295 & 0.364 \\
\hline & $\begin{array}{l}\text { Equal variances } \\
\text { not assumed }\end{array}$ & & & 0.224 & 74.501 & 0.824 & 0.035 & 0.155 & -0.274 & 0.343 \\
\hline \multirow[t]{2}{*}{ Consultative } & $\begin{array}{l}\text { Equal variances } \\
\text { assumed }\end{array}$ & 0.108 & 0.742 & 1.224 & 165 & 0.223 & 0.242 & 0.198 & -0.148 & 0.632 \\
\hline & $\begin{array}{l}\text { Equal variances } \\
\text { not assumed }\end{array}$ & & & 1.239 & 66.665 & 0.220 & 0.242 & 0.195 & -0.148 & 0.632 \\
\hline \multirow[t]{2}{*}{ Enthusiastic } & $\begin{array}{l}\text { Equal variances } \\
\text { assumed }\end{array}$ & 0.004 & 0.950 & 0.249 & 165 & 0.803 & 0.041 & 0.165 & -0.284 & 0.367 \\
\hline & $\begin{array}{l}\text { Equal variances } \\
\text { not assumed }\end{array}$ & & & 0.251 & 65.979 & 0.803 & 0.041 & 0.164 & -0.286 & 0.369 \\
\hline \multirow[t]{2}{*}{ Risk averse } & $\begin{array}{l}\text { Equal variances } \\
\text { assumed }\end{array}$ & 0.001 & 0.971 & -0.232 & 165 & 0.817 & -0.057 & 0.245 & -0.540 & 0.427 \\
\hline & $\begin{array}{l}\text { Equal variances } \\
\text { not assumed }\end{array}$ & & & -0.244 & 70.879 & 0.808 & -0.057 & 0.234 & -0.523 & 0.409 \\
\hline \multirow[t]{2}{*}{ Compassionate } & $\begin{array}{l}\text { Equal variances } \\
\text { assumed }\end{array}$ & 0.576 & 0.449 & -0.504 & 165 & 0.615 & -0.118 & 0.234 & -0.579 & 0.344 \\
\hline & $\begin{array}{l}\text { Equal variances } \\
\text { not assumed }\end{array}$ & & & -0.514 & 67.582 & 0.609 & -0.118 & 0.229 & -0.575 & 0.339 \\
\hline \multirow[t]{2}{*}{ Egocentric } & $\begin{array}{l}\text { Equal variances } \\
\text { assumed }\end{array}$ & 0.004 & 0.952 & 0.644 & 165 & 0.520 & 0.172 & 0.267 & -0.355 & 0.699 \\
\hline & $\begin{array}{l}\text { Equal variances } \\
\text { not assumed }\end{array}$ & & & 0.657 & 67.524 & 0.513 & 0.172 & 0.262 & -0.351 & 0.695 \\
\hline \multirow[t]{2}{*}{ Non-explicit } & $\begin{array}{l}\text { Equal variances } \\
\text { assumed }\end{array}$ & 0.028 & 0.866 & -0.805 & 165 & 0.422 & -0.221 & 0.275 & -0.764 & 0.322 \\
\hline & $\begin{array}{l}\text { Equal variances } \\
\text { not assumed }\end{array}$ & & & -0.779 & 62.263 & 0.439 & -0.221 & 0.284 & -0.789 & 0.346 \\
\hline \multirow[t]{2}{*}{ Distant } & $\begin{array}{l}\text { Equal variances } \\
\text { assumed }\end{array}$ & 0.004 & 0.953 & 0.701 & 165 & 0.484 & 0.173 & 0.247 & -0.314 & 0.661 \\
\hline & $\begin{array}{l}\text { Equal variances } \\
\text { not assumed }\end{array}$ & & & 0.690 & 63.712 & 0.493 & 0.173 & 0.251 & -0.329 & 0.675 \\
\hline \multirow[t]{2}{*}{ Cautious } & $\begin{array}{l}\text { Equal variances } \\
\text { assumed }\end{array}$ & 1.513 & 0.220 & 0.229 & 165 & 0.819 & 0.053 & 0.229 & -0.400 & 0.505 \\
\hline & $\begin{array}{l}\text { Equal variances } \\
\text { not assumed }\end{array}$ & & & 0.206 & 56.208 & 0.837 & 0.053 & 0.255 & -0.458 & 0.563 \\
\hline \multirow[t]{2}{*}{ Organized } & $\begin{array}{l}\text { Equal variances } \\
\text { assumed }\end{array}$ & 0.028 & 0.866 & -0.009 & 165 & 0.993 & -0.001 & 0.147 & -0.291 & 0.288 \\
\hline & $\begin{array}{l}\text { Equal variances } \\
\text { not assumed }\end{array}$ & & & -0.010 & 69.385 & 0.992 & -0.001 & 0.142 & -0.284 & 0.281 \\
\hline \multirow[t]{2}{*}{ Informed } & $\begin{array}{l}\text { Equal variances } \\
\text { assumed }\end{array}$ & 0.000 & 0.997 & 0.904 & 165 & 0.367 & 0.163 & 0.180 & -0.193 & 0.519 \\
\hline & $\begin{array}{l}\text { Equal variances } \\
\text { not assumed }\end{array}$ & & & 0.896 & 64.474 & 0.374 & 0.163 & 0.182 & -0.200 & 0.526 \\
\hline Logical & $\begin{array}{l}\text { Equal variances } \\
\text { assumed }\end{array}$ & 0.043 & 0.836 & 0.166 & 165 & 0.869 & 0.025 & 0.153 & -0.277 & 0.328 \\
\hline
\end{tabular}




\begin{tabular}{|c|c|c|c|c|c|c|c|c|c|c|}
\hline & $\begin{array}{l}\text { Equal variances } \\
\text { not assumed }\end{array}$ & & & 0.162 & 63.135 & 0.872 & 0.025 & 0.157 & -0.288 & 0.339 \\
\hline \multirow[t]{2}{*}{ Sensitive } & $\begin{array}{l}\text { Equal variances } \\
\text { assumed }\end{array}$ & 5.278 & 0.023 & 1.669 & 165 & 0.097 & 0.345 & 0.207 & -0.063 & 0.753 \\
\hline & $\begin{array}{l}\text { Equal variances } \\
\text { not assumed }\end{array}$ & & & 1.881 & 81.501 & 0.063 & 0.345 & 0.183 & -0.020 & 0.710 \\
\hline \multirow[t]{2}{*}{ Communicative } & $\begin{array}{l}\text { Equal variances } \\
\text { assumed }\end{array}$ & 0.875 & 0.351 & 1.150 & 165 & 0.252 & 0.211 & 0.183 & -0.151 & 0.572 \\
\hline & $\begin{array}{l}\text { Equal variances } \\
\text { not assumed }\end{array}$ & & & 1.325 & 85.335 & 0.189 & 0.211 & 0.159 & -0.105 & 0.527 \\
\hline \multirow[t]{2}{*}{ Procedural } & $\begin{array}{l}\text { Equal variances } \\
\text { assumed }\end{array}$ & 0.332 & 0.565 & 0.576 & 165 & 0.566 & 0.143 & 0.249 & -0.348 & 0.635 \\
\hline & $\begin{array}{l}\text { Equal variances } \\
\text { not assumed }\end{array}$ & & & 0.604 & 71.041 & 0.548 & 0.143 & 0.237 & -0.330 & 0.616 \\
\hline \multirow[t]{2}{*}{ Class-conscious } & $\begin{array}{l}\text { Equal variances } \\
\text { assumed }\end{array}$ & 0.658 & 0.418 & -0.011 & 165 & 0.992 & -0.004 & 0.332 & -0.659 & 0.652 \\
\hline & $\begin{array}{l}\text { Equal variances } \\
\text { not assumed }\end{array}$ & & & -0.010 & 60.635 & 0.992 & -0.004 & 0.349 & -0.702 & 0.695 \\
\hline \multirow[t]{2}{*}{ Self-sacrificial } & $\begin{array}{l}\text { Equal variances } \\
\text { assumed }\end{array}$ & 0.691 & 0.407 & -2.076 & 165 & 0.039 & -0.517 & 0.249 & -1.008 & -0.025 \\
\hline & $\begin{array}{l}\text { Equal variances } \\
\text { not assumed }\end{array}$ & & & -1.970 & 60.425 & 0.053 & -0.517 & 0.262 & -1.041 & 0.008 \\
\hline \multirow[t]{2}{*}{ Patient } & $\begin{array}{l}\text { Equal variances } \\
\text { assumed }\end{array}$ & 1.488 & 0.224 & 1.508 & 165 & 0.134 & 0.281 & 0.186 & -0.087 & 0.648 \\
\hline & $\begin{array}{l}\text { Equal variances } \\
\text { not assumed }\end{array}$ & & & 1.523 & 66.535 & 0.132 & 0.281 & 0.184 & -0.087 & 0.649 \\
\hline \multirow[t]{2}{*}{ Honest } & $\begin{array}{l}\text { Equal variances } \\
\text { assumed }\end{array}$ & 0.058 & 0.809 & -0.658 & 165 & 0.511 & -0.114 & 0.173 & -0.454 & 0.227 \\
\hline & $\begin{array}{l}\text { Equal variances } \\
\text { not assumed }\end{array}$ & & & -0.674 & 67.980 & 0.503 & -0.114 & 0.169 & -0.450 & 0.223 \\
\hline \multirow[t]{2}{*}{ Coordinator } & $\begin{array}{l}\text { Equal variances } \\
\text { assumed }\end{array}$ & 0.000 & 0.992 & 0.086 & 165 & 0.931 & 0.015 & 0.171 & -0.323 & 0.352 \\
\hline & $\begin{array}{l}\text { Equal variances } \\
\text { not assumed }\end{array}$ & & & 0.085 & 63.778 & 0.933 & 0.015 & 0.174 & -0.333 & 0.362 \\
\hline \multirow[t]{2}{*}{ Team builder } & $\begin{array}{l}\text { Equal variances } \\
\text { assumed }\end{array}$ & 1.849 & 0.176 & -1.287 & 165 & 0.200 & -0.172 & 0.134 & -0.437 & 0.092 \\
\hline & $\begin{array}{l}\text { Equal variances } \\
\text { not assumed }\end{array}$ & & & -1.161 & 56.472 & 0.250 & -0.172 & 0.149 & -0.470 & 0.125 \\
\hline \multirow[t]{2}{*}{$\begin{array}{l}\text { Performance- } \\
\text { oriented }\end{array}$} & $\begin{array}{l}\text { Equal variances } \\
\text { assumed }\end{array}$ & 2.653 & 0.105 & -1.881 & 165 & 0.062 & -0.385 & 0.205 & -0.790 & 0.019 \\
\hline & $\begin{array}{l}\text { Equal variances } \\
\text { not assumed }\end{array}$ & & & -1.701 & 56.628 & 0.095 & -0.385 & 0.227 & -0.839 & 0.068 \\
\hline \multirow[t]{2}{*}{ Ambitious } & $\begin{array}{l}\text { Equal variances } \\
\text { assumed }\end{array}$ & 0.248 & 0.619 & 0.967 & 165 & 0.335 & 0.201 & 0.208 & -0.209 & 0.610 \\
\hline & $\begin{array}{l}\text { Equal variances } \\
\text { not assumed }\end{array}$ & & & 0.982 & 67.129 & 0.330 & 0.201 & 0.204 & -0.207 & 0.608 \\
\hline \multirow[t]{2}{*}{ Micro-manager } & $\begin{array}{l}\text { Equal variances } \\
\text { assumed }\end{array}$ & 0.777 & 0.379 & 2.707 & 165 & 0.008 & 0.759 & 0.281 & 0.205 & 1.313 \\
\hline & $\begin{array}{l}\text { Equal variances } \\
\text { not assumed }\end{array}$ & & & 2.862 & 71.967 & 0.006 & 0.759 & 0.265 & 0.230 & 1.288 \\
\hline \multirow[t]{2}{*}{ Avoids negatives } & $\begin{array}{l}\text { Equal variances } \\
\text { assumed }\end{array}$ & 0.379 & 0.539 & -0.384 & 165 & 0.702 & -0.113 & 0.294 & -0.693 & 0.467 \\
\hline & $\begin{array}{l}\text { Equal variances } \\
\text { not assumed }\end{array}$ & & & -0.395 & 68.657 & 0.694 & -0.113 & 0.285 & -0.682 & 0.457 \\
\hline
\end{tabular}




\section{APPENDIX D \\ English Version of the Questionnaire}

\section{Instructions}

You are probably aware of people in your organization or industry who are exceptionally skilled at motivating, influencing, or enabling you, others, or groups to contribute to the success of the organization or task. We might call such people "outstanding leaders."

On the following pages are several behaviors and characteristics that can be used to describe leaders. Each behavior or characteristic is accompanied by a short definition to clarify its meaning.

Using the above description of outstanding leaders as a guide, rate the behaviors and characteristics on the following pages. To do this, on the line next to each behavior or characteristic, write the number from the scale below that best describes how important that behavior or characteristic is for a leader to be outstanding.

\section{SCALE}

$1=$ This behavior or characteristic greatly inhibits a person from being an outstanding leader.

$2=$ This behavior or characteristic somewhat inhibits a person from being an outstanding leader.

$3=$ This behavior or characteristic slightly inhibits a person from being an outstanding leader.

$4=$ This behavior or characteristic has no impact on whether a person is an outstanding leader.

$5=$ This behavior or characteristic contributes slightly to a person being an outstanding leader.

$6=$ This behavior or characteristic contributes somewhat to a person being an outstanding leader.

$7=$ This behavior or characteristic contributes greatly to a person being an outstanding leader.

\section{Questions}

1) Diplomatic $=$ Skilled at interpersonal relations, tactful 
2) Evasive $=$ Refrains from making negative comments to maintain good relationships and save face

3) Mediator $=$ Intervenes to solve conflicts between individuals

4) Bossy $=$ Tells subordinates what to do in a commanding way

5) Positive $=$ Generally optimistic and confident

6) Intra-group competitor = Tries to exceed the performance of others in his or her group

7) Independent = Does not rely on others; self-governing

8) Tender = Easily hurt or offended

9) Improvement-oriented $=$ Seeks continuous performance improvement

10) Inspirational = Inspires emotions, beliefs, values, and behaviors of others, inspires others to be motivated to work hard

11) Anticipatory $=$ Anticipates, attempts to forecast events, considers what will happen in the future

12) Risk taker $=$ Willing to invest major resources in endeavors that do not have high probability of successful

13) Sincere $=$ Means what he/she says; earnest

14) Trustworthy = Deserves trust, can be believed and relied upon to keep his/her word

15) Intra-group conflict avoider $=$ Avoids disputes with members of his or her group

16) Administratively skilled = Able to plan, organize, coordinate, and control work of large numbers (over 75) of individuals

17) Win/win problem solver $=$ Able to identify solutions which satisfy individuals with diverse and conflicting interests

18) Clear = Easily understood

19) Self-interested $=$ Pursues own best interests

20) Loyal = Stays with and supports friends even when they have substantial problems or difficulties

21) Collaborative $=$ Works jointly with others

22) Encouraging = Gives courage, confidence, or hope through reassuring and advising

23) Orderly = Is organized and methodological in work

24) Autocratic $=$ Makes decisions in dictatorial way

25) Secretive $=$ Tends to conceal information from others

26) Fraternal $=$ Tends to be a good friend of subordinates

27) Generous $=$ Willing to give time, money, resources, and help to others

28) Formal $=$ Acts in accordance with rules, convention, and ceremonies 
29) Modest $=$ Does not boast; presents self in a humble manner

30) Intelligent $=$ Smart; learns and understands easily

31) Decisive $=$ Makes decisions firmly and quickly

32) Consultative $=$ Consults with others before making plans or taking action

33) Enthusiastic $=$ Demonstrates and imparts strong positive emotions for work

34) Risk averse $=$ Avoids taking risks; dislikes risk

35) Compassionate $=$ Has empathy for others; inclined to be helpful or show mercy

36) Egocentric = Self-absorbed; thoughts focus mostly on one's self

37) Non-explicit $=$ Subtle, does not communicate explicitly, communicates by metaphor, et allegory, et example

38) Distant $=$ Aloof, stands off from others, difficult to become friends with

39) Cautious $=$ Proceeds/performs with great care and does not take risks

40) Organized $=$ Well organized, methodical, orderly

41) Informed = Knowledgeable; aware of information

42) Logical $=$ Applies logic when thinking

43) Sensitive = Aware of slight changes in other's moods; restricts discussion to prevent embarrassment

44) Communicative $=$ Communicates with others frequently

45) Procedural $=$ Follows established rules and guidelines

46) Class conscious $=$ Is conscious of class and status boundaries and acts accordingly

47) Self-sacrificial $=$ Foregoes self-interests and makes personal sacrifices in the interest of a goal or vision

48) Patient $=$ Has and shows patience

49) Honest $=$ Speaks and acts truthfully

50) Coordinator $=$ Integrates and manages work of subordinates

51) Team builder $=$ Able to induce group members to work together

52) Performance-oriented $=$ Sets high standards of performance

53) Ambitious = Sets high goals; works hard

54) Micro-manager $=$ An extremely close supervisor, one who insists on making all decisions

55) Avoids negatives = Avoids saying no to another when requested to do something, even when it cannot be done

56) Age

57) Gender 
58) Education level

59) The province you are living

60) Email address (voluntary) 


\section{APPENDIX E \\ Chinese Version of the Questionnaire}

问卷调查

使用说明:

您可能知道组织或行业中的人, 他们在激励, 影响或使您, 其他人或团体为组织或任 务的成功做出贡献方面非常熟练。我们可以称这些人为“杰出领导人”。

在接下来的页面上，有几种行为和特征可以用来描述领导者。每个行为或特征都附带 一个简短的定义，以阐明其含义。

使用以上对杰出领导者的描述作为指导, 在接下来的页面中对行为和特征进行评分。 为此, 在每个行为或特征旁边的行上, 从下面的刻度中写下最能描述领导者杰出的行 为或特征的重要性的数字。

测评标准:

$1=$ 这种行为或特征极大地阻碍了一个人成为杰出的领导者。

$2=$ 这种行为或特征在某种程度上抑制了一个人成为杰出的领导者。

$3=$ 这种行为或特征会稍微抑制一个人成为杰出的领导者。

$4=$ 这种行为或特征对一个人是否是杰出的领导者没有影响。

$5=$ 这种行为或特征对一个人成为杰出领导者的贡献很小。

$6=$ 这种行为或特征在一定程度上有助于一个人成为杰出的领导者。

$7=$ 这种行为或特征极大地有助于一个人成为杰出的领导者。

问卷内容：

特征或行为及定义

1、精于人际交往型：善于处理人际关系，善于外交

2、规避型：避免对下属进行负面评价, 来维持良好关系和保留颜面

3、调解人型: 调解组内下属之间的冲突矛盾

4、爱发号施令: 以居高临下的姿态告诉下属应该做什么

5、积极的：通常都乐观和自信

6、组内竞争者: 一心致力于超越组内其他人的业绩

7、独立的：不依赖他人，能自主的

8、敏感脆弱型：容易被（某人某事）伤害和刺痛

9、以进步为目标 (进步导向型) : 追求不断的（业绩、表现）进步

10、激励型: 激励他人, 调动他人积极性去更好的工作

11、有预见性的：试图预见可能发生的事，考虑未来会发生什么

12、风险参与者：愿意将主要资源都投入于成功率可能不高的事业

13、真诚的: 心口合一

14、值得信任的：可靠的, 能信守自己的承诺

15、规避组内的冲突: 能有效避免自己组内成员之间的纠纷 
16、具有管理能力: 能有效计划、组织、协调和控制（多有 75 人）多人的组织

17、双赢问题解决者: 能想办法解决问题的同时, 又能满足不同人的或多样或冲突的 利益, 来实现双赢

18、明确的：能使下属很容易又很明确地理解他/她表达的意思

19、自私的：追求自己利益的最大化

20、忠诚的：能陪伴和支持身边的朋友，即使朋友们遇到了重大困难

21、合作型：在工作中愿意并能与他人一起合作

22、温暖鼓励型：通过鼓励和开导的方式给予他人勇气、自信和希望

23、有条理的：在工作中有条理、有方法

24、专制的：以独断的方式来做决定

25、遮遮掩掩的：会对他人隐瞒某些信息

26、兄弟般的：会和下属成为很好的朋友

27、慷慨大方的：愿意帮助他人，愿意给予自己的时间、金钱和资源给他人

28、正规型：严格遵循制度、公约和礼节

29、谦逊的: 不自夸, 表现出一个谦虚的态度

30、睿智的: 聪明, 有较好的学习和理解能力

31、果断的: 能坚定而快速的做好决定

32、协商型：在做计划和行动前会与他人协商

33、充满热情：对工作表现出强烈的积极的情绪

34、规避风险型：避免冒险的行为或决策

35、有同情心：对他人抱有同情心和怜悯

36、自我为中心型：以自我为中心，考虑事情时主要集中于自己

37、不明确: 交流时不明确得表达, 喜欢用寓言或例子, 而非直接明确的表达

38、有距离感的: 让人感觉很难与之成为朋友

39、谨慎型：日常表现得非常小心，不喜欢冒险

40、组织型：善于组织大家，有方法有秩序的组织大家

41 、有知识的: 很有学识

42、有逻辑的：思考问题和行事上很有逻辑

43、敏锐型: 能敏锐得捕捉他人微小的情绪变化, 照顾他人情绪避免话题使人塩尬

44、交流型：能经常地与下属沟通交流

45、循规蹈矩型：严格遵守既定流程和规则

46、有阶级意识: 会注意并关注人与人之间的阶级和地位差异, 言行上会根据地位阶 级来应对不同的人

47、自我牺牲型: 不顾自身利益, 为组织目标和计划牺牲自我利益

48、耐心的: 很有耐心, 并对他人表现出耐心

49、诚实: 言行诚实可靠

50、统筹者: 能很好的统筹管理下属的工作

51、团队建设者: 有能力组织自己组内的成员凝聚起来一起工作

52、注重业绩（业绩导向型）：对业绩制定很高的标准

53、有野心有雄心: 有远大理想抱负, 并会为之努力

54、细微管理者: 坚持参与并制定团队内的每一个决定, 任何微小的事情都要亲力亲 为、不放过

55、避免否定型：被要求做某事时，难以拒绝，会避免说“不”，即使这个要求有些难 以完成 
56、您的性别:

57、您的年龄:

58、您的最高学历:

59、您经常生活的省份

60、您如果对本项研究感兴趣, 并有兴趣且愿意接受之后简短的电话采访, 请留下邮 箱地址（或有可能之后会通过邮箱联系您） 